NBER WORKING PAPER SERIES

\title{
THE GEOGRAPHY OF CROWDFUNDING
}

\author{
Ajay K. Agrawal \\ Christian Catalini \\ Avi Goldfarb \\ Working Paper 16820 \\ http://www.nber.org/papers/w16820 \\ NATIONAL BUREAU OF ECONOMIC RESEARCH \\ 1050 Massachusetts Avenue \\ Cambridge, MA 02138 \\ February 2011
}

We thank Pierre Azoulay, Iain Cockburn, Gary Dushnitsky, Richard Florida, Jeff Furman, Ig Horstmann, Nicola Lacetera, Karim Lakhani, Matt Marx, Ed Roberts, Tim Simcoe, Scott Stern, Will Strange, Catherine Tucker, Pai-Ling Yin, and seminar participants at MIT, the Roundtable on Engineering and Entrepreneurship Research at Georgia Tech, Boston University, the Martin Prosperity Institute, the MIT Open Innovation Conference, and the University of Toronto for comments. We thank Liz Lyons who provided excellent research assistance. We also thank Johan Vosmeijer and Dagmar Heijmans, co-founders of Sellaband, for their industry insights and overall cooperation with this study. This research was funded by the Martin Prosperity Institute, the Centre for Innovation and Entrepreneurship at the Rotman School of Management, the NET Institute (www.netinst.org), and the Social Sciences and Humanities Research Council of Canada. Errors remain our own. The views expressed herein are those of the authors and do not necessarily reflect the views of the National Bureau of Economic Research.

NBER working papers are circulated for discussion and comment purposes. They have not been peerreviewed or been subject to the review by the NBER Board of Directors that accompanies official NBER publications.

(C) 2011 by Ajay K. Agrawal, Christian Catalini, and Avi Goldfarb. All rights reserved. Short sections of text, not to exceed two paragraphs, may be quoted without explicit permission provided that full credit, including $(\mathrm{C}$ notice, is given to the source. 
The Geography of Crowdfunding

Ajay K. Agrawal, Christian Catalini, and Avi Goldfarb

NBER Working Paper No. 16820

February 2011

JEL No. G21,G24,L17,R12,Z11

\begin{abstract}
$\underline{\text { ABSTRACT }}$
Perhaps the most striking feature of "crowdfunding" is the broad geographic dispersion of investors in small, early-stage projects. This contrasts with existing theories that predict entrepreneurs and investors will be co-located due to distance-sensitive costs. We examine a crowdfunding setting that connects artist-entrepreneurs with investors over the internet for financing musical projects. The average distance between artists and investors is about 3,000 miles, suggesting a reduced role for spatial proximity. Still, distance does play a role. Within a single round of financing, local investors invest relatively early, and they appear less responsive to decisions by other investors. We show this geography effect is driven by investors who likely have a personal connection with the artist-entrepreneur ("family and friends"). Although the online platform seems to eliminate most distance-related economic frictions such as monitoring progress, providing input, and gathering information, it does not eliminate social-related frictions.
\end{abstract}

Ajay K. Agrawal

Rotman School of Management

University of Toronto

105 St. George Street

Toronto, ON M5S 3E6

CANADA

and NBER

ajay.agrawal@rotman.utoronto.ca

Christian Catalini

Rotman School of Management

University of Toronto

105 St. George Street

Toronto, ON M5S 3E6

CANADA

christian@catalini.com
Avi Goldfarb

Rotman School of Management

University of Toronto

105 St George St

Toronto, ON M5S 3E6

agoldfarb@rotman.utoronto.ca 


\section{Introduction}

Perhaps the most striking characteristic of crowdfunding is the geographic dispersion of investors. For example, in our data from a crowdfunding website that facilitates investments in early-stage musicians seeking financing, we find a mean distance between artist-entrepreneur and investor of approximately 3,000 miles.

Although distant investors are common for publicly traded companies, theory predicts that investors in early stage entrepreneurial ventures will tend to be local. That is because gathering information, monitoring progress, and providing input are particularly important for investors in early stage ventures and the costs of these activities are sensitive to distance. Most empirical evidence to date supports these claims (Tribus 1970, Florida and Kenney 1988, Florida and Smith 1993, Lerner 1995, Sorenson and Stuart 2001, Powell, Koput, Bowie, and Smith-Doerr 2002, Zook 2002, Mason 2007).

Specifically, Sorenson and Stuart (2005) report that the average distance between lead VC and target firm is approximately 70 miles. Similarly, Sohl (1999) and Wong (2002) report that angel investors locate close to the entrepreneurs they finance (more than $50 \%$ are within half a day of travel).

The geographic dispersion of investment evident in our data implies that crowdfunding in our setting largely overcomes the distance-related economic frictions usually associated with financing entrepreneurial ventures. That is not because the artist-entrepreneurs seeking financing on this site are not early stage. To the contrary, they are unsigned artists seeking capital to record their first album. Most are young, have limited reputations as artists or entrepreneurs, and appear to have minimal resources.

Instead, it appears that the online platform provides an environment purposely designed for early stage entrepreneurs where they can showcase prototypes of their music, present a business plan outlining how they will spend their funds, and directly pitch their project to a 
community of online investors. In this way, and consistent with prior research in retail and advertising that examines how the online setting allows people to overcome offline barriers to market transactions (Choi and Bell 2010, Brynjolfsson, Hu, and Rahman 2009, Goldfarb and Tucker 2010), the platform can help reduce market frictions associated with geographic distance.

Although the role of geography appears to be greatly diminished in our data when we consider aggregate investment at the end of the funding process, an important distinction between local and distant investors comes into sharp relief when we examine investment patterns over time within a single round of financing. We employ a difference-in-differencelike approach to compare first the difference between local and distant investors in terms of their propensity to invest in a given period and then how this difference changes with the publicly visible investment decisions of others. We find that the timing of distant, but not local, investments is very responsive to the investment decisions of others.

Why might local investors differ so greatly from distant investors in their responsiveness to the investment decisions of others? The entrepreneurial finance literature makes frequent reference to the role of family and friends $(\mathrm{F} \& \mathrm{~F})$ as an important source of capital for early stage ventures. ${ }^{1}$ Parker (2009) reports that $31 \%$ of start-ups' funds come from family and friends. Researchers have emphasized family and friends' informational advantages concerning the quality of the entrepreneur. For example, Cumming and Johan (2009) assert that "Apart from the founding entrepreneur's savings, family and friends [...] are a common source of capital for earliest-stage entrepreneurial firms. An entrepreneur without a track record typically has an easier time raising this type of capital because these investors will have known the entrepreneur for a long time. In other words, information asymmetries faced

${ }^{1}$ Despite the acknowledged importance of $\mathrm{F} \& \mathrm{~F}$, there are surprisingly few empirical studies focussed on this form of investment, likely owing to a paucity of data. However, as Cumming and Johan (2009) note, "Recent efforts spurred by the Kaufmann Foundation have begun to fill this gap, but there is significant work to be done in gathering systematic data." 
by [family and friends] are lower than those faced by other sources of capital." Given the local nature of social networks (Hampton and Wellman 2002), these family and friends are disproportionately likely to be local.

We code each investor-entrepreneur pair with an indicator variable for "family and friends" (F\&F) based on particular behavioral traits they exhibit on the website (and check robustness using information from seven entrepreneurs who specifically identified their friends and family among their investors). We find that F\&F are disproportionately co-located with the entrepreneur, although, importantly, there are also many local investors who are not F\&F and many F\&F investors who are distant. We then apply another "difference" to our empirical analysis, comparing how the effect of other investors' investment decisions on the propensity to invest in a given period is mediated by distance after controlling for F\&F. The distance effect disappears.

We interpret this result as implying that the crowdfunding platform eliminates most distance-related economic frictions normally associated with financing early stage projects, such as acquiring information (e.g., local reputation, stage presence), monitoring progress, and providing input. ${ }^{2}$ However, it does not eliminate frictions associated with the type of information about the entrepreneur that is more likely to be held by personally connected individuals (e.g., tendency to persevere, recover from setbacks, succeed in other endeavors). This interpretation emphasizing the importance of interpersonal relations in entrepreneurial finance is consistent with the findings of Nanda and Khanna (2010), who report that crossborder social networks play a particularly key role when access to capital is especially difficult.

These results lead us to speculate that there may be path dependency in the process of accessing distant investors online. To the extent that distant investors disproportionately rely on information revealed in the investment decisions of others, friends and family might

\footnotetext{
${ }^{2}$ In the following section we point out that although "investors" on crowd-funding sites may have philanthropic or other utility-seeking motivations that are not strictly pecuniary, they are still faced with allocating scarce resources and, as the literature on philanthropy suggests, are influenced by similar transaction costs.
} 
play an important role in making early investments that generate that information. Conti, Thursby, and Rothaermel (2010) argue that investments by family and friends can signal the entrepreneurial commitment to the venture. If true in the crowdfunding setting, this would imply a limitation to the "equal access for all" potential of the internet. Communications technologies enable entrepreneurs from anywhere to access capital globally, but in reality only those entrepreneurs with a sufficient base of offline support may be able to do so.

Although crowdfunding is presently small in terms of overall economic activity, it is growing in both the variety of sectors to which is applied (e.g., music, sports, video games, education, retail) and the overall value of transactions (Lawton and Marom 2010). Crowdfunding systems enable users to make investments in various types of projects and ventures, often in small amounts, outside of a regulated exchange, using online social media platforms that facilitate direct interaction between investors as well as with the individual(s) raising funds. To our knowledge this is the first empirical examination of the geography of crowdfunding. ${ }^{3}$

\section{Empirical Setting}

\subsection{Sellaband}

Sellaband is an Amsterdam-based, online platform that enables unsigned musicians to raise financing to produce an album. Launched on August 15, 2006, it was one of the first mainstream websites of its kind and has been referred to as the "granddaddy of crowdfunding"

\footnotetext{
${ }^{3}$ There are several interesting papers on the peer-to-peer lending site Prosper.com. However, none address the spatial dimension of transactions. Perhaps the most related of these, Freedman and Jin (2010), focuses on complementarity between endorsements and monetary commitments. While this work does not address the issue of geography, it does look at online networks. Specifically, Freedman and Jin focus on the role of online social groups in supporting online borrowers, which is complementary to our focus on offline social ties ("friends and family") influencing the financing of online entrepreneurs. Also related is Zhang and Liu (2010), who examine when cumulative investment serves as a quality signal for future investments. Less directly related, Pope and Sydnor (2010) use Prosper.com as an empirical setting to study the effect of race on peer-to-peer lending.
} 
(Kappel 2009). At the time of our data, the Sellaband website worked as follows: ${ }^{4}$

Musical artists set up a profile page on Sellaband, at no charge, where they include a photo, bio, links, blog postings, and up to three demo songs. ${ }^{5}$ Investors search the website, learn about artist-entrepreneurs, listen to their demos and, if they choose, buy one or more shares in an artist's future album at $\$ 10$ per share. Investors see information posted by the artist as well as how much financing the artist has raised to date. Figure 1 provides a picture of a typical artist profile. Funds raised are held in escrow and may not be accessed until the artist has sold 5,000 shares (raising $\$ 50,000$ ). Upon raising $\$ 50,000$, the artist may spend those funds according to a plan they develop that is approved by Sellaband to record their album. As they incur expenses, they send vendor invoices to Sellaband for payment. After the album is completed, the revenues from album sales are split equally three ways between the artist, investors, and Sellaband. Investors also receive a compact disc (CD). During our period of observation, approximately three years, 34 artists raised the full $\$ 50,000$.

The individuals and groups posting their music on Sellaband are typically early-stage artists who have never signed a contract with a record label, recorded a professional album, or performed live outside of local pubs or cafes. At this stage of their careers, their income from live shows and music sales is negligible. In other words, these individuals face many of the same financing challenges and constraints as entrepreneurs in many other settings. Artists on Sellaband use it to raise capital to finance the recording of an album. They market themselves, develop a budget, create a plan for promoting their product, and raise financing. Sellaband therefore provides a platform for artists to engage in entrepreneurial activities with a community of investors. For these reasons, we refer to them as "entrepreneurs" throughout

\footnotetext{
${ }^{4}$ The website has changed substantially since September 2009, reducing the focus on early-stage artists, limiting the ability to receive a monetary return, and allowing more flexibility to artists in the amount they can raise and how they can use their funds.

${ }^{5}$ A "demo," short for "demonstration recording," is an informal recording made solely for the purpose of pitching a song rather than for release. It is effectively a prototype of the song that they plan to later record professionally. It is a way for musicians to approximate their ideas and convey them to record labels, producers, or other artists (Passman 2009).
} 
the paper.

Similarly, in describing our results we refer to the people providing funds as "investors". Of course, many of these investors may also have philanthropic or other utility seeking motivations. Some crowdfunding platforms are explicitly designed with philanthropic intentions. For example, Kiva, a platform which focuses on lending to entrepreneurs in developing countries, does not allow lenders to charge interest and thus provides no mechanism for earning a return on their capital. On Sellaband, a platform designed to accommodate profit-seeking investment motivations by way of a revenue sharing agreement that is tied to the level of investment, individuals may also be motivated by non-pecuniary returns such as utility from being philanthropic to help artists achieve their goals. However, even philanthropicallymotivated individuals must allocate scarce resources. While they may not be focused on a pecuniary return on investment, they are focused on some type of return on their investment and therefore are motivated to select wisely amongst many projects competing for their donations. As Stanley Katz states in his Handbook chapter on philanthropy in the arts (Katz 2006), philanthropic initiatives are increasingly "demanding short-term, measurable deliverables contracted up-front with grantees, and holding grantees strictly accountable for what they do and do not do (Porter and Kramer (1999); Rimel (1999)). At the "venture" end of the new philanthropy, the entrepreneurial techniques of venture capital are being applied (Letts, Ryan, and Grossman (1997)). Donees are analogized to start-up firms, donors partner with them, establishing specific and measurable benchmarks, and continuing their investments only if periodic goals are met" (page 1311). Sellaband artist-entrepreneurs compete for investors. They pitch their projects and enter into contracts that commit them to sharing their revenue with investors. In summary, even individuals who commit funds to projects for non-pecuniary reasons are likely to be sensitive to the types of costs that traditionally favor financial transactions between co-located individuals. As such, we refer to individuals who participate in crowdfunding as investors throughout the paper, keeping 
in mind that they may not be motivated by purely pecuniary returns on their investment.

\subsection{Data}

Our data contain every investment made on Sellaband from its launch in August 2006 until September 2009. Over this period, there were 4,712 artist-entrepreneurs on Sellaband who received at least one $\$ 10$ investment. Of these, 34 raised the $\$ 50,000$ required to access their capital to finance the making of their album. The distribution of investments in these entrepreneurs is highly skewed: these 34 raised $73 \%$ of the $\$ 2,322,750$ invested on the website.

To explore the role of geography in the crowdfunding of early-stage entrepreneurial projects, we used geographic information disclosed by entrepreneurs and investors on Sellaband. For entrepreneurs, location was cross-checked with their official website, MySpace, and Facebook profiles. We used the Google Maps APIs ${ }^{6}$ to retrieve latitude and longitude for each location ${ }^{7}$ and to standardize city names. We then manually checked locations and in the case of multiple or ambiguous matches either cleaned further or coded as missing. Finally, we calculated geodesic distances between entrepreneurs and investors using a method developed by Thaddeus Vincenty and implemented by Austin Nichols (Nichols 2003). In our focal sample, we have distance measures for $90 \%$ of entrepreneur-investor pairs.

The other data we use in our main specifications is the cumulative investment raised by the entrepreneur from all investors as of the previous week. In some specifications, we also use song and video uploads that entrepreneurs post on the website and investor proximity to concert locations (and the dates of those concerts).

We focus our analysis on investments in the 34 entrepreneurs who raised $\$ 50,000$, examining the timing of investment and types of investors. We focus on these 34 for several reasons. First, they are more comparable with each other in terms of their performance on

\footnotetext{
${ }^{6}$ See http://code.google.com/apis/maps/ (accessed 13-04-2010)

${ }^{7}$ According to the data available, we used country, region, city name, and zipcode or country-region-city triads or country-city pairs.
} 
the site because they have each successfully gone through the full funding cycle. Second, we eliminate concerns about right truncation of the data by focusing on entrepreneurs who complete the funding cycle. Third, we have geographic location information for the vast majority of the investors in these 34 entrepreneurs because investors must give their location in order to receive their CD. Fourth, focusing on these 34 eliminates musicians who use Sellaband sporadically and do not treat the platform as a place for entrepreneurial activity. Finally, since these 34 entrepreneurs account for nearly three-quarters of all funds raised on Sellaband, we argue that little information is lost by focusing on them (and our robustness checks to other samples confirm this).

The main sample is therefore constructed by taking the 34 entrepreneurs who reach $\$ 50,000$ during our observation period. Entrepreneurs enter the sample when they receive their first investment and exit when they reach the target. The resulting panel is unbalanced. We identify every investor who invested at least once in one of these 34 entrepreneurs. Investors enter the sample when they make their first investment on Sellaband (in any entrepreneur) because their profile becomes visible to entrepreneurs and other investors at that time. Investors never exit the sample.

Our main $(\$ 50 \mathrm{~K})$ sample of entrepreneur-investor pairs is the Cartesian product of the 34 successful entrepreneurs and all investors who invest at least once in one of them. Each pair appears during each week in which both the entrepreneur and the investor are in the sample. ${ }^{8}$ Because we use entrepreneur-investor pair fixed effects in our regression analysis, pairs with no investments are dropped. There are 18,827 entrepreneur-investor pairs with at least one investment from the investor in the entrepreneur and 709,471 entrepreneur-investor-week observations.

\footnotetext{
${ }^{8}$ For example, if Entrepreneur 1 receives her first investment in week 10 and reaches $\$ 50 \mathrm{~K}$ in week 20 , then she will appear in the sample from weeks 10 through 20. If Investor 2 made his first investment in week 5, then he is paired with Entrepreneur 1 for weeks 10 through 20. If Investor 3 made his first investment in Week 18, then he is paired with Entrepreneur 1 for weeks 18 through 20.
} 
We present descriptive statistics for the $\$ 50 \mathrm{~K}$ sample in Table 1a. Of these successful entrepreneurs, the average takes approximately one year (53 weeks) to reach $\$ 50,000$, although there is considerable variation around the mean from just under two months to more than two years. The source of financing is widely distributed; on average entrepreneurs raise their financing from 609 different investors. Across the $34 \$ 50 \mathrm{~K}$-entrepreneurs, there are 8,149 unique investors. On average, these investors invest in $2.5 \$ 50 \mathrm{~K}$-entrepreneurs, making 4.3 distinct investments (i.e., they often invest on more than one occasion in a single entrepreneur). They invest a total of $\$ 208$ across all $\$ 50 \mathrm{~K}$-entrepreneurs during the period under study. In other words, investors invest $\$ 82$ per entrepreneur, on average (see Figure 2 for a detailed frequency distribution of investment instance magnitudes). In terms of artistic effort, these entrepreneurs post 4.3 demo songs on their profile during the fundraising process, above and beyond the songs they post when they first launch their profile. ${ }^{9}$

In the full sample of entrepreneurs (Table 1b), the average entrepreneur only has 11.4 investors. Overall, investors spend an average of $\$ 150$ on Sellaband, spread over 3.5 entrepreneurs and 5.5 different investment occasions.

\subsection{Geographic variance on Sellaband}

Figure 3a presents the geographic distribution of the 34 entrepreneurs who raise $\$ 50 \mathrm{~K}$. They are distributed over five continents with the majority in Europe and the United States. Figure 3b illustrates the geographic distribution of investors in these entrepreneurs. They represent 80 countries and are also particularly concentrated in Europe and the eastern United States.

Table 2 illustrates the quantity of investment by distance. Table 2a splits distance into

\footnotetext{
${ }^{9}$ Many entrepreneurs launch their profile with three songs - the maximum number the system accommodates. It is likely that all of these $\$ 50 \mathrm{~K}$-entrepreneurs launched their profile with three songs, meaning the average number of songs per entrepreneur is $7.3(3+4.3)$. We only have data on songs added, not the number of songs posted at the time of launching a new profile.
} 
five groups. The average investment level within $50 \mathrm{~km}$ is significantly higher than the investment level over $50 \mathrm{~km}$, conditional on investing. In order to simplify the analysis, we group all entrepreneur-investor pairs within $50 \mathrm{~km}$ as "local" and all others as "distant." The idea is that "being local" involves an easy commute by car or public transit. Our results are robust to other thresholds. Table $2 \mathrm{~b}$ shows that although local investments are on average higher than distant, $\$ 196$ compared to $\$ 74$, there are many more distant investors and therefore in aggregate they account for the vast majority of total investments. In other words, conditional on making an investment, local investors invest on average 2.6 times that of distant investors.

Local investors are also more likely to invest in a particular entrepreneur. Conditional on making at least one investment in any entrepreneur on Sellaband, $11.4 \%$ of individuals who are local to an entrepreneur invest. In contrast, only $1.5 \%$ of distant investors who are distant to an entrepreneur invest. In this way, investors are disproportionately local.

\section{Empirical Strategy}

Our econometric analysis is a straightforward framework at the entrepreneur-investor-week level. Investor $i$ will invest in entrepreneur $e$ in week $t$ if the expected value from investment is positive:

$$
v_{e i t}=\beta \text { CumulativeInv }_{\text {et }-1}+\gamma X_{e i t}+\mu_{e i}+\psi_{t}+\epsilon_{e i t}
$$

where $v_{e i t}$ is the value of investing in entrepreneur $e$ at time $t$ by investor $i$. The value from investment includes both the monetary expected return of investment as well as any consumption utility derived from investing in that entrepreneur. $\beta$ is the perceived marginal value of cumulative investment as of the previous week. For example, a higher cumulative investment may indicate that more investors perceive the entrepreneur to be of high quality and therefore a better investment. Alternatively, investors may derive more consumption 
utility from investing in entrepreneurs who are closer to the $\$ 50 \mathrm{~K}$ threshold. In our main specification, CumulativeInv $v_{e-1}$ is included as a vector of dummy variables defined by the $\$ 10000$ cumulative investment thresholds. In addition, $\gamma$ is the perceived marginal value of the controls $\left(X_{\text {eit }}\right)$ including a control for time since the entrepreneur began on Sellaband, $\mu_{e i}$ is an entrepreneur-investor fixed effect to control for overall tastes of the investor, $\psi_{t}$ is a week fixed effect to control for changes in the Sellaband environment over time, and $\epsilon_{\text {eit }}$ is an idiosyncratic error term.

Because $v_{\text {eit }}$ is a latent variable, we instead examine the decision to invest. Therefore, to understand the value to the investor in investing in entrepreneur $e$ at time $t$ we use the following discrete choice specification:

$$
\mathbf{1}\left(\text { Invest }_{\text {eit }}\right)=\beta \text { CumulativeInv } v_{\text {et }-1}+\gamma X_{\text {eit }}+\mu_{e i}+\psi_{t}+\epsilon_{\text {eit }}
$$

Consistent with the suggestions of Angrist and Pischke (2009), we estimate this using a linear probability model although we show robustness to alternative specifications. Likely because our covariates are binary, the vast majority of the predicted probabilities of our estimates lie between zero and one. Therefore the potential bias of the linear probability model is reduced in our estimation (Horrace and Oaxaca 2006). The fixed effects mean that our analysis examines the timing of investment for entrepreneur-investor pairs where we observe at least one investment. The fixed effects completely capture the entrepreneurinvestor pairs in which we never see investment, and these pairs can therefore be removed from the analysis without any empirical consequences. Standard errors are clustered at the entrepreneur-investor pair level. Cumulative investment is measured at the entrepreneurweek level. Because the average entrepreneur in our main sample has over 600 investors, the 
cumulative investment number is not driven by any individual investor. ${ }^{10}$

In order to understand the role of distance, we separately estimate local and distant entrepreneur-investor pairs. ${ }^{11}$

$$
\begin{gathered}
\mathbf{1}\left(\text { Invest }_{\text {eit }}\right)=\beta^{l} \text { CumulativeInv } \text { et }-1+\gamma X_{\text {eit }}^{l}+\mu_{e i}^{l}+\psi_{t}^{l}+\epsilon_{\text {eit }}^{l} \quad \text { if local } \\
\mathbf{1}\left(\text { Invest }_{\text {eit }}\right)=\beta^{d} \text { CumulativeInv }_{\text {et }-1}+\gamma X_{\text {eit }}^{d}+\mu_{e i}^{d}+\psi_{t}^{d}+\epsilon_{\text {eit }}^{d} \quad \text { if distant }
\end{gathered}
$$

Furthermore, in order to understand the role of $\mathrm{F} \& \mathrm{~F}$, we interact $\mathrm{F} \& \mathrm{~F}$ with cumulative investment in each of these separately estimated local and distant equations.

$$
\begin{aligned}
& \mathbf{1}\left(\text { Invest }_{\text {eit }}\right)=\beta^{l} \text { CumulativeInv }{ }_{e t-1}+\theta^{l} F \& F_{e i} \times C \text { umulativeInv } v_{e t-1}+\gamma X_{\text {eit }}^{l}+\mu_{e i}^{l}+\psi_{t}^{l}+\epsilon_{\text {eit }}^{l} \text { if local } \\
& \mathbf{1}\left(\text { Invest }_{\text {eit }}\right)=\beta^{d} \text { CumulativeInv } v_{\text {et }-1}+\theta^{d} F \& F_{\text {ei }} \times \text { CumulativeInv } v_{\text {et }-1}+\gamma X_{\text {eit }}^{d}+\mu_{e i}^{d}+\psi_{t}^{d}+\epsilon_{\text {eit }}^{d} \text { if distant }
\end{aligned}
$$

The main effect of F\&F will drop out due to collinearity with the entrepreneur-investor fixed effects. With this empirical approach we examine when an investor chooses to invest in a particular entrepreneur, conditional on at least one investment by that investor in that entrepreneur. Investors often invest more than once in the same entrepreneur during a single $\$ 50,000$ round of fundraising. We assume that the timing of investment is driven by the change in cumulative investment rather than by another change that is specific to the entrepreneur-investor pair. We also assume that the entrepreneur-investor and week fixed

\footnotetext{
${ }^{10} \mathrm{We}$ address the potential for bias due to the use of fixed effects when several investors invest just once by showing robustness to random effects and to limiting the sample to investors who invest in the entrepreneur at least twice.

${ }^{11}$ We estimate separately for clarity of presentation. All results are robust to using interaction terms in simultaneous estimation of local and distance.
} 
effects as well as other covariates control for omitted variables. Our main results hold as long as there is not an omitted variable that drives lagged cumulative investment, an increase in the value of distant investing, and a simultaneous decrease in the value of local investing. One plausible variable that might fit such a description is concert touring. As an entrepreneur gains visibility, they may be more able to tour to more distant locations. We therefore show that our results are robust to controls for touring.

\section{Results}

We build our results in three steps. First, we document that investors' propensity to invest in a given week increases as the entrepreneur visibly accumulates capital on the site. Second, we show that local investors do not follow this pattern. Instead they are most likely to invest early in the cycle, before an entrepreneur has raised $\$ 10,000$. Finally, we show that this difference between local and distant investors is entirely explained by the group of investors we label Friends and Family (F\&F). The results are robust to numerous specifications, some of which appear in the paper and some in the appendix. ${ }^{12}$

\subsection{Investment propensity increases with funds raised}

In Table 3 we show that investment propensity increases as an entrepreneur accumulates investment. Column (1) reports the main results using the $\$ 50 \mathrm{~K}$ sample. The use of the $\$ 50 \mathrm{~K}$ sample ensures this is not a simple selection story where only the better entrepreneurs appear in the sample with higher cumulative investment. Relative to an entrepreneur with less than $\$ 10,000$ in investment, a given investor is 2.1 percentage points more likely to invest

\footnotetext{
${ }^{12}$ In the main tables we focus on a core specification and a handful of key robustness checks. In the appendix we verify that our results are robust to numerous alternative specifications of the sample chosen, covariates used, and functional forms.
} 
in a given week if the entrepreneur has $\$ 10,000-\$ 20,000$ and 8.4 percentage points more likely to invest if they have more than $\$ 40,000$. These increases are large relative to a weekly base rate of $4.1 \%$ during the first $\$ 10,000$. We illustrate the estimates of the increase in propensity to invest in a given week over different capital levels in Figure 4. Because we use a linear probability model, this means we can simply plot the coefficient values.

Column (2) shows that the qualitative result is robust to using the full sample of all entrepreneurs. Column (3) shows robustness to a fixed-effects linear regression using quantity invested as the dependent variable rather than a dummy for whether an investment occurred. Column (4) shows robustness to including controls for artistic effort including posting videos and songs to the website and giving live performances in the investor's locale. Videos and concerts are positively related to investments but their inclusion does not affect the relationship between cumulative investment and propensity to invest. ${ }^{13}$

Overall, Table 3 shows that investment accelerates as an entrepreneur gets closer to $\$ 50,000$. This is consistent with Zhang and Liu (2010) who document a similar pattern on Prosper.com. Like Zhang and Liu (2010), we argue that this is suggestive evidence of path dependency: past investment may increase the propensity to invest. It is only suggestive

\footnotetext{
${ }^{13}$ For this table, as well as tables 4 and 6 , we show robustness to several more specifications in the appendix. Table A1 repeats the main results of the paper to facilitate comparison. In terms of the sample, we show robustness to the full sample (Table A2), the sample of entrepreneurs who reach $\$ 1000$ in investments (Table A3), the sample of entrepreneurs who reach $\$ 5,000$ in investments (Table A4), the sample constructed by dropping entrepreneurs from the Netherlands (the home country of the website) (Table A5), the sample constructed by dropping entrepreneurs from the music hubs of New York City, Los Angeles, Nashville, London, and Paris (Tables A6 and A7), to including only investors who invest two or more times (Table A8), and to using as unit of analysis the entrepreneur-investor-month (Table A9). In terms of covariates, we show robustness to defining cumulative investment as appearing on the Sellaband "charts" as one of the 25 artist-entrepreneurs closest to raising $\$ 50,000$ (Table A10), to including just video and song uploads (Table A11), to including just whether the entrepreneur performed in the investor's locale (Table A12), to including videos, songs, and performances (Table A13), to removing focal investor's past investment from the entrepreneur's accumulated capital (Table A14), and to including whether the entrepreneur appeared in the Sellaband Newsletter (Table A15). In terms of the functional form, we show robustness to fixed-effects logit (Table A16), fixed-effects poisson regression on the total parts invested (Table A17), linear regression on the total parts invested and (when applicable) disinvested (Table A18), to random effects (Table A19). The appendix also shows robustness of Tables 4 and 6 to alternative measures of "local" (Tables A20 and A21), treating missing geographic information as distant (Table A22), combining distant and local in the same regression and using interactions (Table A23), to alternative definitions of F\&F (Table A24).
} 
because, in the absence of a truly exogenous shock to investment, we cannot reject the possibility that some other activity may cause the acceleration in investment. Nevertheless, to the extent that the fixed effects and the covariates on entrepreneurial effort control such activities, the underlying pattern in the data, combined with the prominent placement of cumulative investment information on the website, suggest that high levels of cumulative investment may cause an increase in the rate at which new investment arrives.

\subsection{Local and distant investors are different}

In Table 4 we stratify the data between local and distant investors. Local investors are more likely to invest over the first $\$ 20,000$ than later. In contrast, the results for distant investors resemble the overall results shown in Table 3. Columns (1) and (2) show our main specification. In Figure 5 we provide a graphical representation of the propensity to invest at different stages in the investment cycle. Local and distant investors clearly display distinct patterns; distant investors' propensity to invest rises as the entrepreneur accumulates capital, whereas local investors' propensity does not.

As mentioned above, our interpretation of these results holds as long as there is not an omitted variable that drives lagged cumulative investment, an increase in the value of distant investing, and a decrease in the value of local investing. In columns (3) and (4) we address the possibility that entrepreneurs increase their effort to attract distant investors as they become more successful. They might perform concerts further from home or they might post more material on their website. Specifically, we show robustness to whether the entrepreneur performs within $50 \mathrm{~km}$ of the investor and whether the entrepreneur posted a new song or video to their website. The qualitative differences between local and distant investment patterns remain.

In the appendix, we show that this general relationship is broadly robust to many other specifications. The only notable difference in a few of the robustness checks is a flat relation- 
ship between investment propensity and cumulative investment for local investors, rather than a decreasing relationship. Still, the clear distinction between distant and local holds in all cases: distant investors significantly increase their propensity to invest as the entrepreneur accumulates capital whereas local investors do not.

\subsection{Friends and Family}

In this section we show that a particular type of investor, whom we label as "Friends and Family" (F\&F) of a particular entrepreneur, explains the observed difference between local and distant investors. These individuals likely joined this market-making platform to fund that particular entrepreneur. We define F\&F by the following three characteristics:

1. The F\&F investor invested in the focal entrepreneur before investing in any other (i.e. the investor is likely to have joined the system for the focal entrepreneur)

2. The F\&F investor's investment in the focal entrepreneur is their largest investment

3. The investor invests in no more than three other entrepreneurs (i.e. the focal entrepreneur remains a key reason for being on the site)

To confirm the validity of our measure, we received information from seven successful entrepreneurs on Sellaband on the investors they knew independently of Sellaband. Specifically, we asked them to identify from their list of investors all family members and friends that they knew prior to joining Sellaband. Our measure captured $76 \%$ of the investors that these seven entrepreneurs identified, as well as a number of investors that the entrepreneurs did not know personally. We later show that the difference between F\&F and others holds when we limit the sample to these seven entrepreneurs and their hand-coded list of F\&F.

In Table 5 we provide descriptive statistics for the F\&F sample. Using investor-level measures of the use of the website's communications tools (emails sent through the website 
and comments on webpages), in Table 5a we show that they use Sellaband less intensively than other investors. Specifically, they send approximately 34 times fewer emails, post 29 times fewer comments, receive five times fewer emails, and receive 16 times fewer comments than non-F\&F investors, on average. We conjecture that F\&F might behave differently on the Sellaband site because they interact with the entrepreneur through other channels. Overall, these data suggest that $\mathrm{F} \& \mathrm{~F}$ are a distinct group.

Furthermore, in Table 5b we show that F\&F investors are disproportionately active at the beginning of the investment process. On average, F\&F account for approximately one third of the focal entrepreneur's total investment when they have raised their first $\$ 500$ (or similarly after the first four weeks). In contrast, they account for only one fifth by the end of the fundraising cycle.

In Table 5c we show that although some $\mathrm{F} \& \mathrm{~F}$ investors are distant, they are disproportionately local. In terms of number of investors, F\&F account for $65 \%$ of investors under 25 $\mathrm{km}(61 \%$ between $25-50 \mathrm{~km})$ but only $16 \%$ of distant investors. In terms of dollars, F\&F account for $36 \%$ of investments under $25 \mathrm{~km}$ (60\% between $25-50 \mathrm{~km})$ but only $16 \%$ of distant investment. Together, the statistics in these tables raise the possibility that the difference between local and distant investors might be explained by F\&F.

Next, we run our main specification on local and distant investors, but include an interaction of capital levels with an indicator for F\&F (Table 6). The results show that local and distant investors are qualitatively similar, conditional on F\&F. Particularly, in all specifications, for both local and distant investors, F\&F tend to invest early in the funding cycle and non-F\&F tend to invest later. We illustrate this result in Figure 6 which shows that nonF\&F investors, both local and distant, increase their propensity to invest as the entrepreneur accumulates capital whereas $\mathrm{F} \& \mathrm{~F}$ investors do not.

A potential concern with our interpretation of these results is that our definition only proxies for Friends and Family. It is likely that we include many investors who are not really 
$\mathrm{F} \& \mathrm{~F}$, and that we exclude some investors that are $\mathrm{F} \& \mathrm{~F}$. In order to address this concern, we examined investments in the seven entrepreneurs who identified their Friends and Family to us. By focusing on just these seven entrepreneurs, we do not have enough local investments to identify the coefficients of a local-only regression. Therefore, we combine local and distant investors and re-run the $\mathrm{F} \& \mathrm{~F}$ analysis using all investors in these seven entrepreneurs and the F\&F that they identified. We present the results in Table 7: even with the limited sample, for the $\mathrm{F} \& \mathrm{~F}$ group we see that investment propensity decreases as cumulative investment approaches $\$ 50,000$. Table 7 shows that the results of Table 6 are robust to this more direct definition of $\mathrm{F} \& \mathrm{~F}$. We interpret this result as providing validity for our main definition of $\mathrm{F} \& \mathrm{~F}$.

In summary, our results suggest that there is no systematic difference between local and distant investors, except to the extent that social networks (as measured by F\&F) are disproportionately local.

\subsection{Is this just buying music?}

One potential alternative interpretation of the difference between $F \& F$ and others is that other investors are not investing in the entrepreneur, instead they are simply buying the music in advance. As mentioned above, when investors own shares in an entrepreneur that raises $\$ 50 \mathrm{~K}$, the investor receives a $\mathrm{CD}$. If an investor is really just buying music, it may make sense to wait until the financing is almost complete, and therefore such an investor may invest only when the entrepreneur is close to $\$ 50 \mathrm{~K}$. In Table 8 , we show that the results appear to be driven by more than just differences across groups in the value of the CD. Column (1) shows that the results change very little if we focus only on those investors who invested in the same artist on at least two occasions. This group would derive more value from the first investment than the second since they receive the $\mathrm{CD}$ from their first 
investment, but we still see the same patterns for F\&F versus other investors.

Columns (2) and (3) exploit a policy change on the Sellaband website. Prior to December 2008, investors received a CD for every share that they purchased. Sellaband then changed their policy and only provided a 'free' CD for the first share purchased. Column (2) shows the overall difference between F\&F and others before the policy change and column (3) shows the difference after. The main results of the paper hold: F\&F invest early and others invest late, irrespective of whether a CD is given for each part purchased.

Table 8 therefore suggests that the results are unlikely to be driven by motives related to purchasing music and instead appear to be driven by the expected pecuniary and nonpecuniary returns from investment. To reiterate, we cannot separately identify whether investors are buying shares motivated by pecuniary returns or as a way to receive consumption utility through the potential to support and interact with an early-stage artist.

\section{Conclusion}

We examine the role of distance in an online platform for financing early stage artistentrepreneurs. We find that investment patterns over time are independent of geographic distance between entrepreneur and investor after controlling for the entrepreneur's offline social network. This result contrasts with the existing literature that emphasizes the importance of spatial proximity in entrepreneurial finance. Instead, our result suggests that online mechanisms can reduce economic frictions associated with investing in early-stage projects over long distances. Only the spatial correlation of pre-existing social networks is not resolved, and the online mechanisms do not yet eliminate frictions related to information that is easily conveyed through a social network. This is consistent with prior research on online activity that shows many, but not all, distance-related frictions are reduced in the online setting (Blum and Goldfarb 2006, Hortacsu, Martinez-Jerez, and Douglas 2009). 
Furthermore, our result emphasizes the important role that friends and family may play online and offline in generating early investment in entrepreneurial ventures. Consistent with Conti, Thursby, and Rothaermel (2010), we speculate that this early investment may serve as a signal of entrepreneurial commitment. Later investors may use this signal thereby increasing the likelihood of further funding by way of access to distant sources of capital.

Finally, we comment on the implications of crowdfunding in our particular industry setting, recorded music. Over the past two decades, this industry has experienced significant changes. Industry revenues have declined by approximately $50 \%$ over 10 years, which many industry experts attribute to piracy through online file sharing (Passman 2009). At the same time, costs associated with the production and distribution of music have also dropped substantially due to the development of inexpensive production software and the digital distribution of music over the internet. However, production costs are not zero and recording artists are commonly cash constrained. In the vertically integrated industry set-up, large record companies provided both financing and a full suite of services (e.g., producer, studio, cover design, distribution, auxiliary musicians) in exchange for ownership of or equity in the artists' intellectual property. As the major labels decline in importance, artists have fewer options to relieve cash constraints by borrowing against, or selling equity in, their intellectual property. Crowdfunding helps overcome that constraint by creating a market for the most salient asset available to aspiring new artists - their ideas, vision, and future intellectual property - thereby facilitating financing from distant strangers. Thus, crowdfunding may help reduce an important market failure. 


\section{References}

Angrist, J. D., And J.-S. Pischke (2009): Mostly Harmless Econometrics: An Empiricist's Companion. Princeton University Press: Princeton NJ.

Blum, B., And A. Goldfarb (2006): "Does the internet defy the law of gravity?," Journal of International Economics, 70(2), 384-405.

Brynjolfsson, E., Y. J. Hu, and M. S. Rahman (2009): "Battle of the Retail Channels: How Product Selection and Geography Drive Cross-Channel Competition," Management Science, 55 (11), 1755-1765.

Choi, J., And D. Bell (2010): "Preference Minorities and the Internet," Working paper, Wharton.

Conti, A., M. Thursby, and F. T. Rothaermel (2010): "Show Me the Right Stuff: Signals for High-Tech Startups," Working paper, College of Management, Georgia Institute of Technology.

Cumming, Douglas, J., and S. A. Johan (2009): Venture Capital and Private Equity Contracting: An International Perspective. Academic Press.

Florida, R., AND D. Smith (1993): "Venture capital formation, investment and regional Industrialization," Annals of the Association of American Geographers, 83(3), 434-5.

Florida, R. L., And M. Kenney (1988): "Venture Capital, High Technology and Regional Development," Regional Studies, 22, 33-48.

Freedman, S., and G. Z. Jin (2010): "Learning by Doing with Asymmetric Information: evidence from Propser.com," Working paper.

Goldfarb, A., And C. Tucker (2010): "Advertising Bans and the Substitutability of Online and Offline Advertising," Journal of Marketing Research, (forthcoming).

Hampton, K., and B. Wellman (2002): "Neighboring in Netville: How the Internet supports community and social capital in a wired suburb," City and Community, 2(3), $277-311$.

Horrace, W. C., and R. L. Oaxaca (2006): "Results on the bias and inconsistency of ordinary least squares for the linear probability model," Economic Letters, 90, 321-327.

Hortacsu, A., F. A. Martinez-Jerez, and J. Douglas (2009): "The Geography of Trade in Online Transactions: Evidence from eBay and MercadoLibre.," American Economic Journal: Microeconomics, 1(1), 53-74.

KAPPEL, T. (2009): "Ex ante crowdfunding and the recording industry: a model for the U.S.?," LLAE Law Review, 29, 375-385. 
Katz, S. N. (2006): Handbook of The Economics of Art and Culture -chap. Philanthropy, pp. 1300-1321, no. 37. North-Holland.

Lawton, K., and D. Marom (2010): The Crowdfunding Revolution. Social Networking Meets Venture Financing. Amazon Digital Services.

Lerner, J. (1995): "Venture Capitalists and the Oversight of Private Firms," Journal of Finance, 50, 310-318.

Mason, C. (2007): "Venture capital: a geographical perspective," in H Landström (ed) Handbook of Research on Venture Capital, Edward Elgar, Cheltenham, pp. 86-112.

Nanda, R., And T. Khanna (2010): "Diasporas and Domestic Entrepreneurs: Evidence from the Indian Software Industry," Journal of Economics and Management Strategy, (forthcoming).

Nichols, A. (2003): "Vincenty: Stata module to calculate distances on the Earth's surface," Statistical Software Components.

PARker, S. C. (2009): The Economics of Entrepreneurship. Cambridge University Press.

Passman, D. (2009): All you need to know about the music business. Free Press, New York.

Pope, D., And J. Sydnor (2010): "What's in a Picture? Evidence of Discrimination on Prosper.com," Journal of Human Resources, forthcoming.

Powell, W. W., K. W. Koput, J. I. Bowie, and L. Smith-Doerr (2002): "The Spatial Clustering of Science and Capital: Accounting for Biotech Firm-Venture Capital Relationships," Regional Studies, 36(3), 291-305.

Simcoe, T. (2007): "XTPQML: Stata module to estimate Fixed-effects Poisson (Quasi-ML) regression with robust standard errors," Statistical Software Components, Boston College Department of Economics.

SoHL, J. E. (1999): "The early-stage equity market in the USA," Venture Capital: An International Journal of Entrepreneurial Finance, 1, 101-120.

Sorenson, O., And T. E. Stuart (2001): "Syndication Networks and the Spatial Distribution of Venture Capital Investments," American Journal of Sociology, 106(6), 15461588.

(2005): "The Evolution of venture capital investment networks," Working paper.

Tribus, M. (1970): "Panel on government and new business proceedings," Venture Capital and Management, Management Seminar, Boston College, Boston, MA, May 28.

Wong, A. (2002): "Angel Finance: The Other venture capital," University of Chicago Graduate School of Business Working Paper. 
Zhang, J., And P. LiU (2010): "Observational Learning in Microloan Markets: Evidence from Prosper.com.," Working paper, MIT.

Zook, M. A. (2002): "Grounded capital: venture financing and the geography of the Internet industry, 1994-2000," Journal of Economic Geography, 2(2), 151-177. 
Table 1a: Descriptive stats - $\$ 50 \mathrm{~K}$ (main) Sample

\begin{tabular}{|c|c|c|c|c|c|}
\hline & Obs. & Mean & Std. Dev. & Min & $\operatorname{Max}$ \\
\hline \multicolumn{6}{|l|}{ Entrepreneur Level } \\
\hline Investors at $\$ 50 \mathrm{~K}$ & 34 & 608.8 & 220.9 & 316 & 1,338 \\
\hline Weeks to $\$ 50 \mathrm{~K}$ & 34 & 53.1 & 34.6 & 8 & 124 \\
\hline Songs uploaded $\dagger$ & 34 & 4.29 & 8.02 & 0 & 32 \\
\hline Videos uploaded & 34 & 0.68 & 0.47 & 0 & 1 \\
\hline \multicolumn{6}{|l|}{ Investor level } \\
\hline Number of $50 \mathrm{~K}$ entrepreneurs invested in & 8,149 & 2.54 & 4.23 & 1 & 34 \\
\hline Number of distinct investments & 8,149 & 4.33 & 12.78 & 1 & 330 \\
\hline Total amount invested across $50 \mathrm{~K}$ entrepreneurs $(\$)$ & 8,149 & 208 & $1,083.9$ & 0 & 33,430 \\
\hline \multicolumn{6}{|l|}{ Entrepreneur-Investor level } \\
\hline Investment amount $(\$)$ & 18,827 & 82 & 379.8 & 0 & 23,500 \\
\hline Geographic distance (km) & 18,827 & 5,118 & 5,658 & 0.003 & 19,827 \\
\hline Number of investments in same entrepreneur & 18,827 & 1.7 & 2.3 & 1 & 72 \\
\hline Position in funding cycle at first investment $(\$)$ & 18,827 & 12,099 & 13,361 & 0 & 49,990 \\
\hline \multicolumn{6}{|l|}{ Entrepreneur-Investor-Week level } \\
\hline Investment amount $(\$)$ & 709,471 & 2.378 & 40.82 & 0 & 15,000 \\
\hline Live show proximate to investor & 709,471 & 0.002 & 0.046 & 0 & 1 \\
\hline
\end{tabular}


Table 1b: Descriptive stats - Full Sample

\begin{tabular}{|c|c|c|c|c|c|}
\hline & Obs. & Mean & Std. Dev. & Min & Max \\
\hline \multicolumn{6}{|l|}{ Entrepreneur Level } \\
\hline Investors & 4,712 & 11.4 & 60.5 & 1 & 1,338 \\
\hline Total Investment & 4,712 & 49.3 & 437.5 & 0 & 5,000 \\
\hline Songs uploaded $\dagger$ & 4,712 & 1.82 & 2.686 & 0 & 59 \\
\hline Videos uploaded & 4,712 & 0.11 & 0.378 & 0 & 8 \\
\hline \multicolumn{6}{|l|}{ Investor level } \\
\hline Number of entrepreneurs invested in & 15,517 & 3.46 & 21.1 & 1 & 1,835 \\
\hline Number of distinct investments & 15,517 & 5.52 & 34.3 .1 & 1 & 2,155 \\
\hline Total amount invested across all entrepreneurs (\$) & 15,517 & 149.7 & 991.9 & 0 & 38,440 \\
\hline \multicolumn{6}{|l|}{ Entrepreneur-Investor level } \\
\hline Investment amount $(\$)$ & 24,862 & 42.69 & 253.61 & 0 & 23,500 \\
\hline Geographic distance (km) & 24,862 & $4,831.5$ & $5,523.6$ & .003 & 19,863 \\
\hline Number of investments in same entrepreneur & 24,862 & 1.79 & 2.52 & 1 & 72 \\
\hline Position in funding cycle at first investment $(\$)$ & 24,862 & 9,998 & 12,464 & 0 & 49,990 \\
\hline \multicolumn{6}{|l|}{ Entrepreneur-Investor-Week level } \\
\hline Investment amount $(\$)$ & $1,175,492$ & 1.83 & 33.71 & 0 & 15,000 \\
\hline
\end{tabular}

$\dagger$ Entrepreneurs may upload 1 to 3 songs when registering on the website. Since we do not have access to these data, the initial songs are not included in this count. 
Table 2a: Local versus Distant - $\$ 50 \mathrm{~K}$ Sample

\begin{tabular}{lrrrr}
\hline Distance & Obs. & Mean Investment & Total Investment & \% of Total \\
\hline $0-5 \mathrm{~km}$ & 191 & 255.76 & 48,850 & $2.9 \%$ \\
$5-50 \mathrm{~km}$ & 973 & 184.62 & 179,640 & $10.6 \%$ \\
$50-500 \mathrm{~km}$ & 4,403 & 67.67 & 297,970 & $17.5 \%$ \\
$500-3,000 \mathrm{~km}$ & 4,232 & 79.56 & 336,680 & $19.8 \%$ \\
$>3,000 \mathrm{~km}$ & 9,028 & 75.15 & 678,410 & $39.9 \%$ \\
Not Available & 1,999 & 79.26 & 158,450 & $9.3 \%$ \\
\hline
\end{tabular}

Table 2b: Local versus Distant, consolidated - \$50K Sample

\begin{tabular}{lrrrr}
\hline & Obs. & Mean Investment & Total Investment & \% of Total \\
\hline Local (under $50 \mathrm{~km}$ ) & 1,164 & 196 & 228,490 & $13.5 \%$ \\
Distant (over 50 km) & 17,663 & 74 & $1,313,060$ & $77.2 \%$ \\
Not Available & 1,999 & 79 & 158,450 & $9.3 \%$ \\
\hline
\end{tabular}


Table 3: Investment propensity increases over time

\begin{tabular}{|c|c|c|c|c|}
\hline & $\begin{array}{c}(1) \\
\$ 50 \mathrm{~K} \text { sample }\end{array}$ & $\begin{array}{c}(2) \\
\text { Full sample }\end{array}$ & $\begin{array}{c}\text { (3) } \\
\text { Total Parts }\end{array}$ & $\begin{array}{c}(4) \\
\text { Additional covariates }\end{array}$ \\
\hline$\$ 10-20 \mathrm{~K}$ accum. capital & $\begin{array}{c}0.0213^{* * *} \\
(0.0012)\end{array}$ & $\begin{array}{c}0.0109^{* * *} \\
(0.0009)\end{array}$ & $\begin{array}{c}0.1216^{* * *} \\
(0.0176)\end{array}$ & $\begin{array}{c}0.0211^{* * *} \\
(0.0012)\end{array}$ \\
\hline$\$ 20-30 \mathrm{~K}$ accum. capital & $\begin{array}{c}0.0261^{* * *} \\
(0.0017)\end{array}$ & $\begin{array}{c}0.0134^{* * *} \\
(0.0012)\end{array}$ & $\begin{array}{c}0.1654^{* * *} \\
(0.0280)\end{array}$ & $\begin{array}{c}0.0277^{* * *} \\
(0.0017)\end{array}$ \\
\hline$\$ 30-40 \mathrm{~K}$ accum. capital & $\begin{array}{c}0.0420^{* * *} \\
(0.0021)\end{array}$ & $\begin{array}{c}0.0266^{* * *} \\
(0.0015)\end{array}$ & $\begin{array}{c}0.2575^{* * *} \\
(0.0353)\end{array}$ & $\begin{array}{c}0.0442^{\text {*** }} \\
(0.0021)\end{array}$ \\
\hline$\$ 40-50 \mathrm{~K}$ accum. capital & $\begin{array}{c}0.0840^{* * *} \\
(0.0027)\end{array}$ & $\begin{array}{c}0.0691^{* * *} \\
(0.0021)\end{array}$ & $\begin{array}{c}0.6279^{* * *} \\
(0.0560)\end{array}$ & $\begin{array}{c}0.0871^{* * *} \\
(0.0027)\end{array}$ \\
\hline Weeks on Sellaband & $\begin{array}{c}-0.0033^{* * *} \\
(0.0003)\end{array}$ & $\begin{array}{c}-0.0032^{* * *} \\
(0.0002)\end{array}$ & $\begin{array}{c}-0.0095^{* * *} \\
(0.0035)\end{array}$ & $\begin{array}{c}-0.0018^{* * *} \\
(0.0002)\end{array}$ \\
\hline Videos uploaded (lagged) & & & & $\begin{array}{l}0.0084^{*} \\
(0.0043)\end{array}$ \\
\hline Songs uploaded (lagged) & & & & $\begin{array}{l}-0.0011 \\
(0.0009)\end{array}$ \\
\hline Investor proximate to Live Show & & & & $\begin{array}{l}0.0098^{*} \\
(0.0056)\end{array}$ \\
\hline Observations & 709,471 & $1,175,492$ & 709,471 & 703,417 \\
\hline R-squared & 0.012 & 0.010 & 0.002 & 0.011 \\
\hline Number of group & 18,827 & 24,862 & 18,827 & 18,827 \\
\hline
\end{tabular}

Dependent variable is any investment in columns (1)-(2)-(4) and total investment in column (3). Unless otherwise specified, sample is the $\$ 50 \mathrm{~K}$ sample. Column (4) adds controls for videos and songs uploaded by the entrepreneur, and live shows proximate to investor. All regressions include a full set of fixed effects for each entrepreneur-investor pair (differenced out) and each week. Robust standard errors clustered at the pair level in parentheses.

*** $\mathrm{p}<0.01, * * \mathrm{p}<0.05, * \mathrm{p}<0.1$ 
Table 4: Local and distant investors are different

\begin{tabular}{|c|c|c|c|c|}
\hline & $\begin{array}{l}(1) \\
\$ 50 \mathrm{~K} \text { sample } \\
\text { LOCAL }\end{array}$ & $\begin{array}{l}\text { (2) } \\
\$ 50 \mathrm{~K} \text { sample } \\
\text { DISTANT }\end{array}$ & $\begin{array}{l}(3) \\
\$ 50 \mathrm{~K} \quad \text { sample } \\
\text { with controls } \\
\text { LOCAL }\end{array}$ & $\begin{array}{l}(4) \\
\$ 50 \mathrm{~K} \quad \text { sample } \\
\text { with controls } \\
\text { DISTANT }\end{array}$ \\
\hline$\$ 10-20 \mathrm{~K}$ accum. capital & $\begin{array}{l}0.0020 \\
(0.0076)\end{array}$ & $\begin{array}{l}0.0215^{* * *} \\
(0.0012)\end{array}$ & $\begin{array}{l}0.0051 \\
(0.0076)\end{array}$ & $\begin{array}{l}0.0212^{* * *} \\
(0.0013)\end{array}$ \\
\hline$\$ 20-30 \mathrm{~K}$ accum. capital & $\begin{array}{l}-0.0287^{* * *} \\
(0.0103)\end{array}$ & $\begin{array}{l}0.0283^{* * *} \\
(0.0017)\end{array}$ & $\begin{array}{l}-0.0258^{* *} \\
(0.0103)\end{array}$ & $\begin{array}{l}0.0299^{* * *} \\
(0.0017)\end{array}$ \\
\hline$\$ 30-40 \mathrm{~K}$ accum. capital & $\begin{array}{l}-0.0334^{* * *} \\
(0.0114)\end{array}$ & $\begin{array}{l}0.0451^{* * *} \\
(0.0021)\end{array}$ & $\begin{array}{l}-0.0309^{* * *} \\
(0.0114)\end{array}$ & $\begin{array}{l}0.0473^{* * *} \\
(0.0021)\end{array}$ \\
\hline$\$ 40-50 \mathrm{~K}$ accum. capital & $\begin{array}{c}-0.0254^{*} \\
(0.0134)\end{array}$ & $\begin{array}{l}0.0891^{* * *} \\
(0.0028)\end{array}$ & $\begin{array}{l}-0.0211 \\
(0.0133)\end{array}$ & $\begin{array}{l}0.0922^{* * *} \\
(0.0028)\end{array}$ \\
\hline Weeks on Sellaband & $\begin{array}{l}-0.0038^{* * *} \\
(0.0011)\end{array}$ & $\begin{array}{l}-0.0032^{* * *} \\
(0.0003)\end{array}$ & $\begin{array}{l}-0.0001 \\
(0.0010)\end{array}$ & $\begin{array}{l}-0.0018^{* * *} \\
(0.0002)\end{array}$ \\
\hline Videos uploaded (lagged) & & & $\begin{array}{l}0.2435^{* * *} \\
(0.0454)\end{array}$ & $\begin{array}{l}0.0011 \\
(0.0042)\end{array}$ \\
\hline Songs uploaded (lagged) & & & $\begin{array}{l}-0.0038 \\
(0.0029)\end{array}$ & $\begin{array}{l}-0.0010 \\
(0.0009)\end{array}$ \\
\hline Investor proximate to Live Show & & & $\begin{array}{l}0.0094 \\
(0.0086)\end{array}$ & $\begin{array}{l}0.0031 \\
(0.0148)\end{array}$ \\
\hline Observations & 57,855 & 651,616 & 57,711 & 645,706 \\
\hline R-squared & 0.042 & 0.012 & 0.042 & 0.012 \\
\hline Number of group & 1,164 & 17,663 & 1,164 & 17,663 \\
\hline
\end{tabular}

Dependent variable is any investment and sample is the $\$ 50 \mathrm{~K}$ sample. Local is defined as within $50 \mathrm{~km}$ from the entrepreneur. Columns (3)-(4) add controls for videos and songs uploaded by the entrepreneur and live shows proximate to investor. All regressions include a full set of fixed effects for each entrepreneur-investor pair (differenced out) and each week. Robust standard errors clustered at the pair level in parentheses. *** $\mathrm{p}<0.01,{ }^{* *} \mathrm{p}<0.05, * \mathrm{p}<0.1$ 
Table 5a: F\&F use the website differently

\begin{tabular}{llc}
\hline & $\mathbf{F \& F}$ & Not $\mathbf{F \& F}$ \\
\hline Average \# of emails sent to entrepreneurs & 0.24 & 8.25 \\
Average \# of comments sent to entrepreneurs & 0.44 & 12.74 \\
Average \# of emails received from entrepreneurs & 13.19 & 68.97 \\
$\begin{array}{l}\text { Average \# of comments received from en- } \\
\text { trepreneurs }\end{array}$ & & 1.14 \\
\hline
\end{tabular}

Table 5b: F\&F are disproportionately active at the beginning

\begin{tabular}{cccc}
\hline & First \$500 & First $\mathbf{4}$ weeks & Full \$50k \\
\hline F\&F & $34 \%$ & $37 \%$ & $22 \%$ \\
Not F\&F & $66 \%$ & $63 \%$ & $78 \%$ \\
\hline
\end{tabular}

Table 5c: F\&F are disproportionately local

\begin{tabular}{cccc}
\hline Pairs & $\mathbf{0 - 2 5} \mathbf{~ k m}$ & $\mathbf{2 5 - 5 0 ~} \mathbf{k m}$ & $>\mathbf{5 0} \mathbf{~ k m}$ \\
\hline F\&F & $65 \%$ & $61 \%$ & $16 \%$ \\
Not F\&F & $35 \%$ & $39 \%$ & $84 \%$ \\
& & & \\
\hline Dollars & $\mathbf{0 - 2 5} \mathbf{~ k m}$ & $\mathbf{2 5 - 5 0 ~} \mathbf{~ k m}$ & $>\mathbf{5 0 ~} \mathbf{~ m}$ \\
\hline F\&F & $36 \%$ & $60 \%$ & $16 \%$ \\
Not F\&F & $64 \%$ & $40 \%$ & $84 \%$ \\
\hline
\end{tabular}




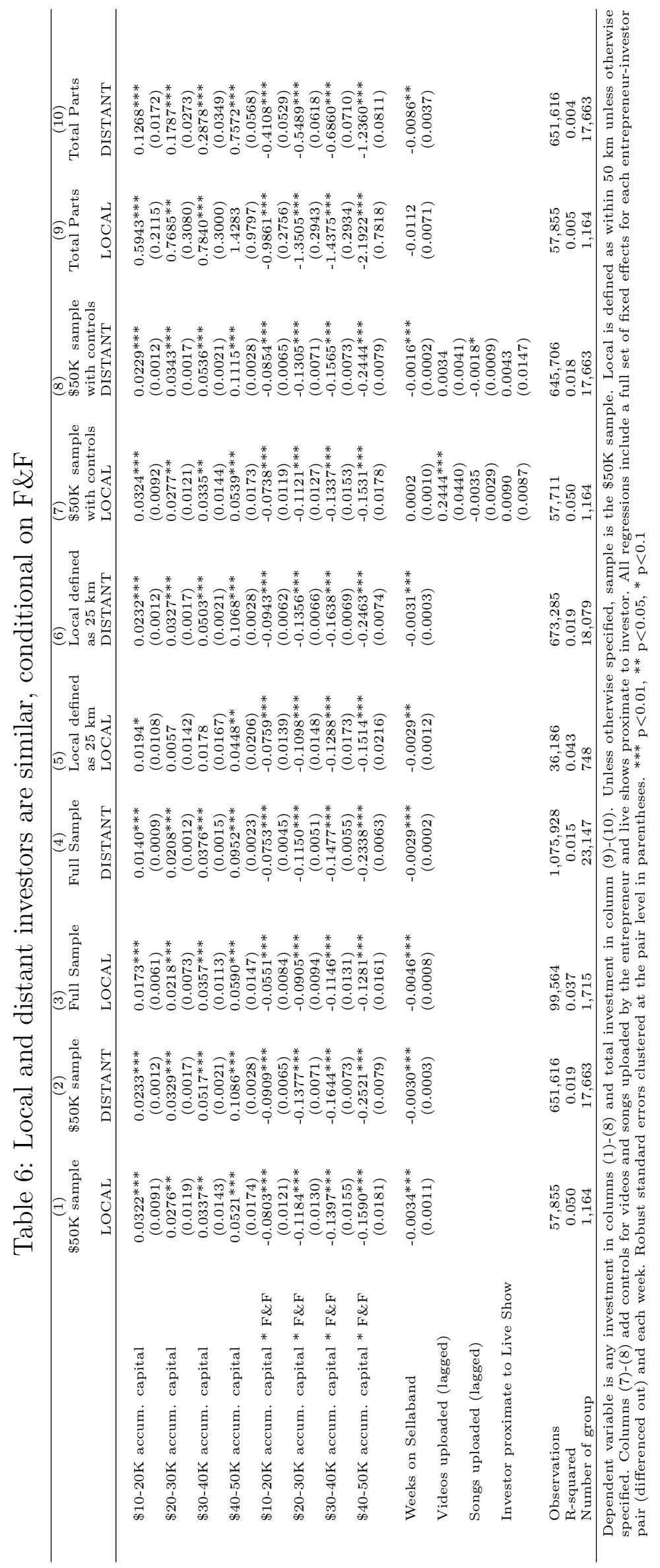


Table 7: F\&F definition based on interviews with seven entrepreneurs

\begin{tabular}{lcc}
\hline VARIABLES & $(1)$ & $(2)$ \\
\hline & & \\
\$10-20K accum. capital & $0.0076^{* *}$ & $0.0096^{* * *}$ \\
\$20-30K accum. capital & $0.0227^{* * *}$ & $(0.0033)$ \\
& $(0.0050)$ & $\left(0.0051^{* * *}\right.$ \\
\$30-40K accum. capital & $0.0280^{* * *}$ & $0.0323^{* * *}$ \\
& $(0.0057)$ & $(0.0059)$ \\
\$40-50K accum. capital & $0.0947^{* * *}$ & $0.1004^{* * *}$ \\
& $(0.0078)$ & $(0.0080)$ \\
\$10-20K accum. capital ${ }^{*} \mathrm{~F} \& \mathrm{~F}$ & $-0.0543^{* *}$ & $-0.0405^{*}$ \\
& $(0.0217)$ & $(0.0212)$ \\
\$20-30K accum. capital * F\&F & $-0.0712^{* * *}$ & $-0.0571^{* * *}$ \\
& $(0.0216)$ & $(0.0209)$ \\
\$30-40K accum. capital * F\&F & $-0.0798^{* * *}$ & $-0.0656^{* *}$ \\
& $(0.0299)$ & $(0.0290)$ \\
\$40-50K accum. capital ${ }^{*} \mathrm{~F} \& \mathrm{~F}$ & $-0.1317^{* * *}$ & $-0.1171^{* * *}$ \\
& $(0.0235)$ & $(0.0227)$ \\
& & \\
Weeks on Sellaband & $-0.0008^{* *}$ & $-0.0008^{* * *}$ \\
& $(0.0004)$ & $(0.0002)$ \\
Videos uploaded (lagged) & & $0.0520^{* * *}$ \\
Songs uploaded (lagged) & & $(0.0104)$ \\
& & $-0.0048^{* *}$ \\
Investor proximate to Live & & $(0.0019)$ \\
Show & & $0.0137^{*}$ \\
& & $(0.0074)$ \\
Observations & & 144,717 \\
Number of group & & 0.025 \\
\hline
\end{tabular}

Dependent variable is any investment. Sample includes all investments in the seven entrepreneurs who identified their Friends and Family. All regressions include a full set of fixed effects for each entrepreneur-investor pair (differenced out) and each week. Column 2 adds controls for songs and videos uploaded by the entrepreneur and live shows proximate to the investor. Local and distant combined for sample size reasons. Robust standard errors clustered at the pair level in parentheses. ${ }^{* * *} \mathrm{p}<0.01,{ }^{* *} \mathrm{p}<0.05,{ }^{*} \mathrm{p}<0.1$ 
Table 8: Only investors who invest two or more times (Column 1). Before and after change in incentives (Columns 2 and 3 ).

\begin{tabular}{|c|c|c|c|}
\hline VARIABLES & $\begin{array}{l}\text { (1) } \\
\text { Full time period }\end{array}$ & $\begin{array}{c}(2) \\
\text { Before } \\
\text { Change in incentives }\end{array}$ & $\begin{array}{c}\text { (3) } \\
\text { After } \\
\text { Change in incentives }\end{array}$ \\
\hline$\$ 10-20 \mathrm{~K}$ accum. capital & $\begin{array}{c}0.0239^{* * * *} \\
(0.0013)\end{array}$ & $\begin{array}{c}0.0229 * * * \\
(0.0013)\end{array}$ & $\begin{array}{c}0.0089 \\
(0.0116)\end{array}$ \\
\hline$\$ 20-30 \mathrm{~K}$ accum. capital & $\begin{array}{c}0.0369 * * * \\
(0.0018)\end{array}$ & $\begin{array}{c}0.0307^{* * *} \\
(0.0017)\end{array}$ & $\begin{array}{c}0.0659 * * * \\
(0.0090)\end{array}$ \\
\hline$\$ 30-40 \mathrm{~K}$ accum. capital & $\begin{array}{c}0.0592^{* * *} \\
(0.0022)\end{array}$ & $\begin{array}{c}0.0527^{* * *} \\
(0.0022)\end{array}$ & $\begin{array}{c}0.0757^{* * *} \\
(0.0097)\end{array}$ \\
\hline$\$ 40-50 \mathrm{~K}$ accum. capital & $\begin{array}{c}0.1174^{* * *} \\
(0.0029)\end{array}$ & $\begin{array}{c}0.1069^{* * *} \\
(0.0030)\end{array}$ & $\begin{array}{c}0.1275^{* * *} \\
(0.0107)\end{array}$ \\
\hline$\$ 10-20 \mathrm{~K}$ accum. capital $*$ F\&F & $\begin{array}{c}-0.0709 * * * \\
(0.0164)\end{array}$ & $\begin{array}{c}-0.1006^{* * *} \\
(0.0053)\end{array}$ & $\begin{array}{l}0.1348^{*} \\
(0.0699)\end{array}$ \\
\hline$\$ 20-30 \mathrm{~K}$ accum. capital $*$ F\&F & $\begin{array}{c}-0.1066^{* * *} \\
(0.0198)\end{array}$ & $\begin{array}{c}-0.1485^{* * *} \\
(0.0057)\end{array}$ & $\begin{array}{c}-0.0840 * * * \\
(0.0274)\end{array}$ \\
\hline$\$ 30-40 \mathrm{~K}$ accum. capital $*$ F\&F & $\begin{array}{c}-0.1345^{* * *} \\
(0.0196)\end{array}$ & $\begin{array}{c}-0.1851^{* * *} \\
(0.0060)\end{array}$ & $\begin{array}{c}-0.1009 * * * \\
(0.0275)\end{array}$ \\
\hline$\$ 40-50 \mathrm{~K}$ accum. capital $*$ F\&F & $\begin{array}{c}-0.1932^{* * *} \\
(0.0225)\end{array}$ & $\begin{array}{c}-0.2729^{* * *} \\
(0.0070)\end{array}$ & $\begin{array}{c}-0.1534^{* * *} \\
(0.0280)\end{array}$ \\
\hline Weeks on Sellaband & $\begin{array}{c}-0.0024^{* * *} \\
(0.0003)\end{array}$ & $\begin{array}{c}-0.0043^{* * *} \\
(0.0004)\end{array}$ & $\begin{array}{l}0.0008^{*} \\
(0.0005)\end{array}$ \\
\hline Observations & 585,803 & 628,732 & 80,739 \\
\hline R-squared & 0.015 & 0.020 & 0.019 \\
\hline Number of group & 14,790 & 18,447 & 3,920 \\
\hline
\end{tabular}

Dependent variable is any investment in columns and sample is the $\$ 50 \mathrm{~K}$ sample. In column (1), only investors who invest at least two or more times are included. Column (2) includes all investments that took place before the change in incentives (December 2008), while column (3) those that happened after. In the before period, investors would receive one CD for every $10 \$$ invested in the entrepreneur. After the incentives change, only the first $10 \$$ would entitle the investor to receive a CD. All regressions include a full set of fixed effects for each entrepreneur-investor pair (differenced out) and each week. Robust standard errors clustered at the pair level in parentheses.

*** $\mathrm{p}<0.01,{ }^{* *} \mathrm{p}<0.05,{ }^{*} \mathrm{p}<0.1$ 
Figure 1: Sellaband screenshot

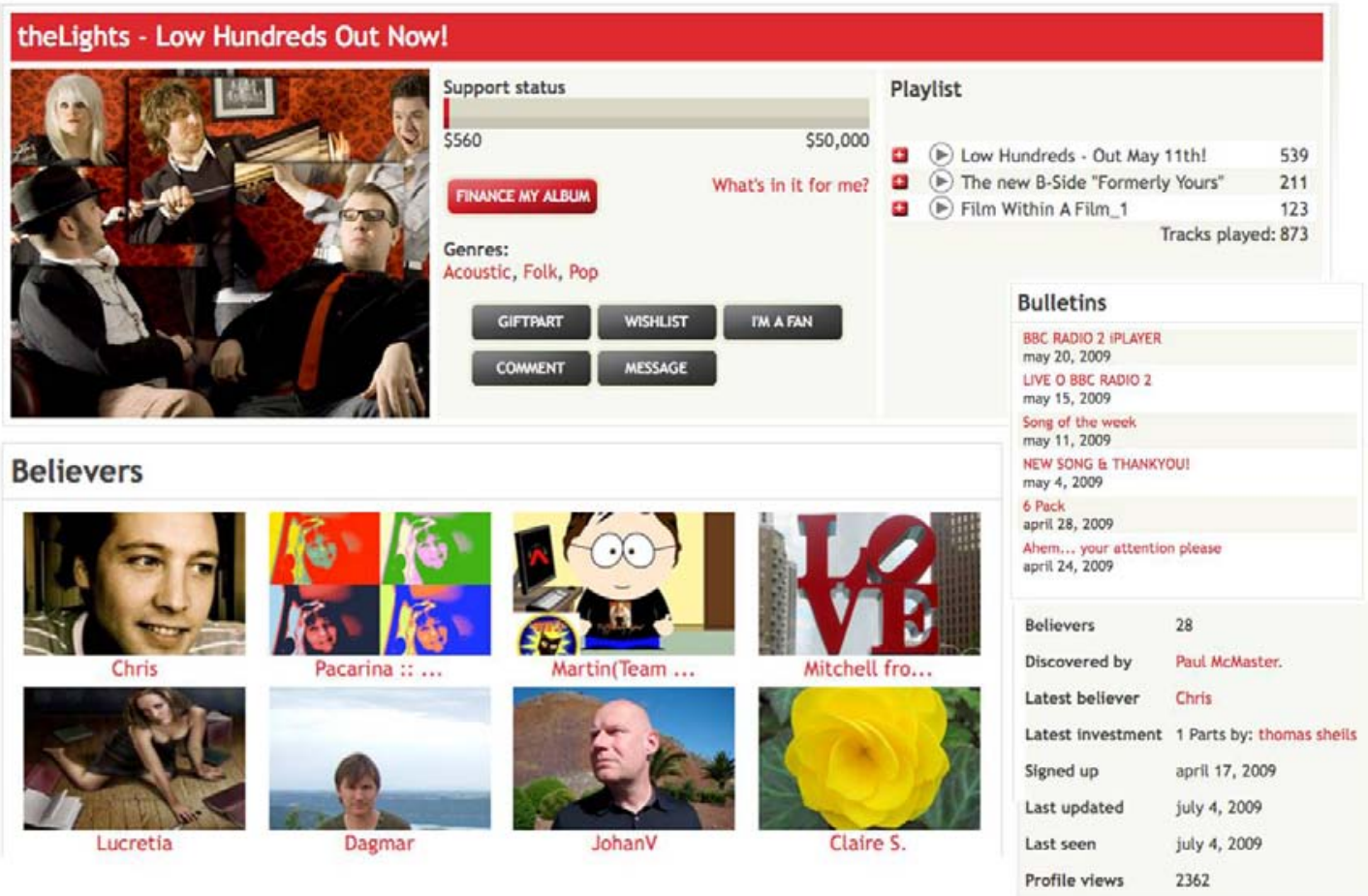

Figure 2: Frequency of investment instance magnitudes (50K sample).

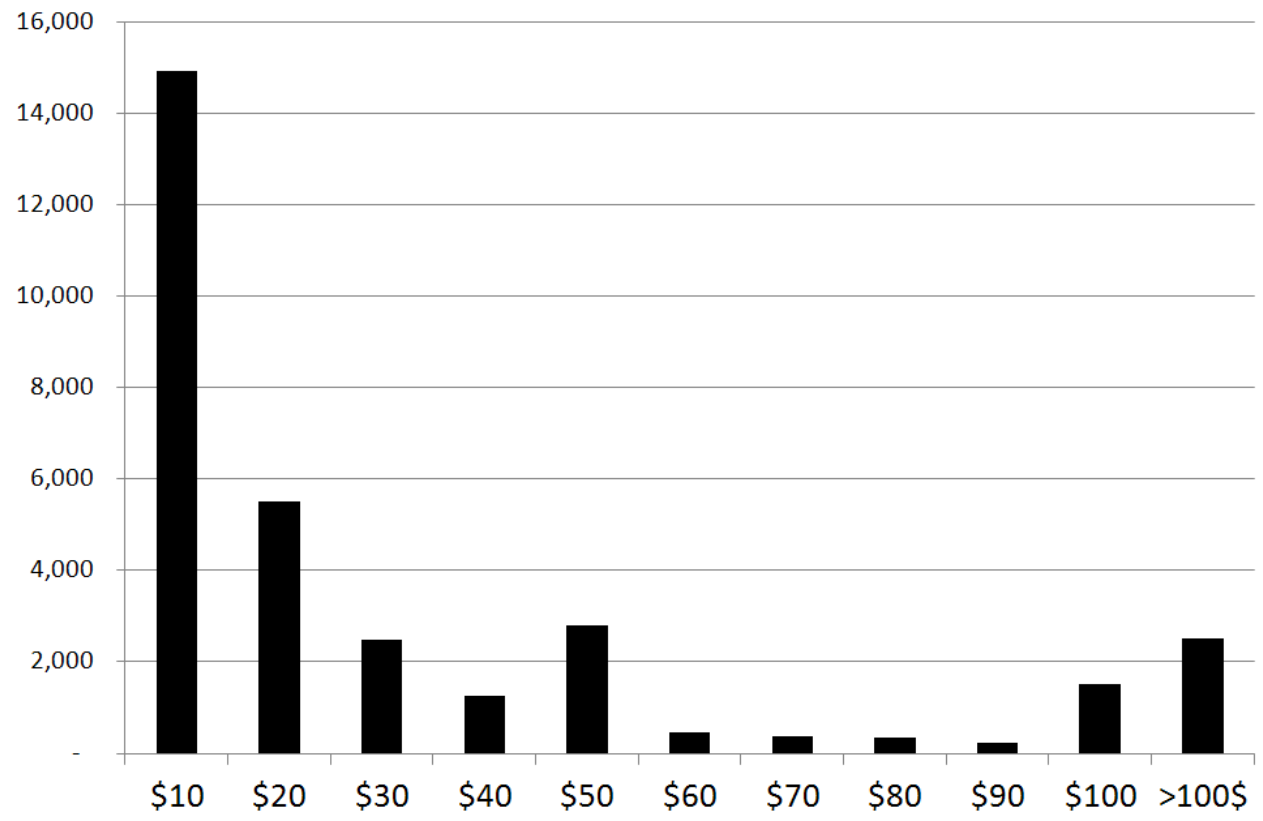


Figure 3a: Map of $\$ 50 \mathrm{~K}$ entrepreneurs locations

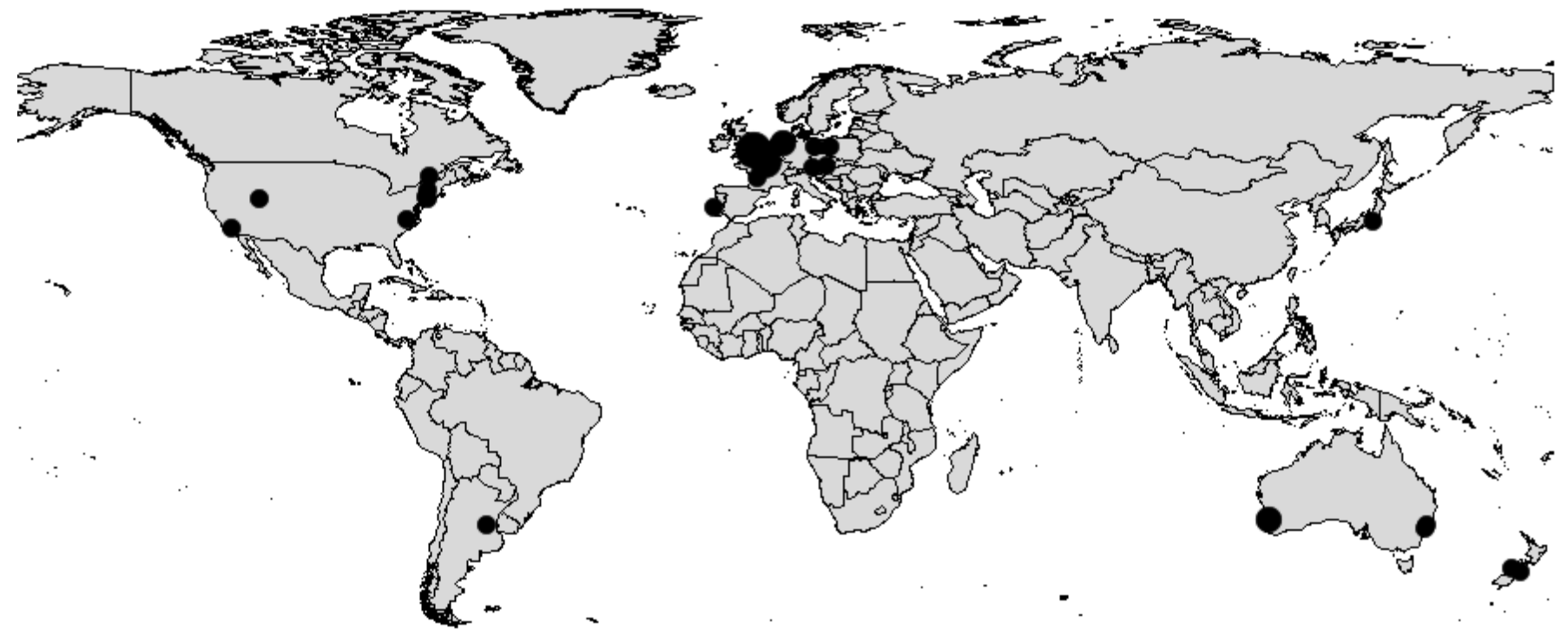

Figure 3b: Map of investor locations ( $\$ 50 \mathrm{~K}$ artists)

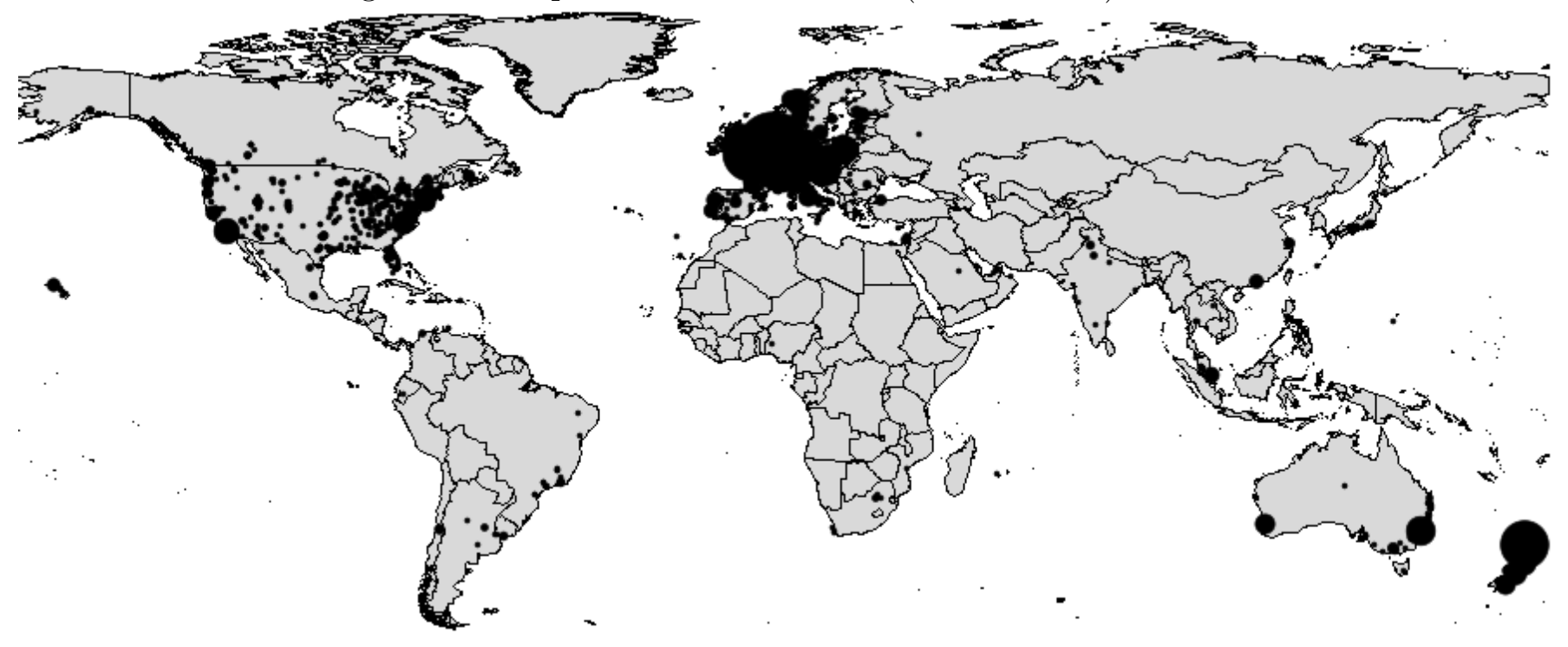


Figure 4: Relative propensity to invest for all investors over capital levels. Baseline is propensity to invest between $\$ 0-10 \mathrm{~K}$.

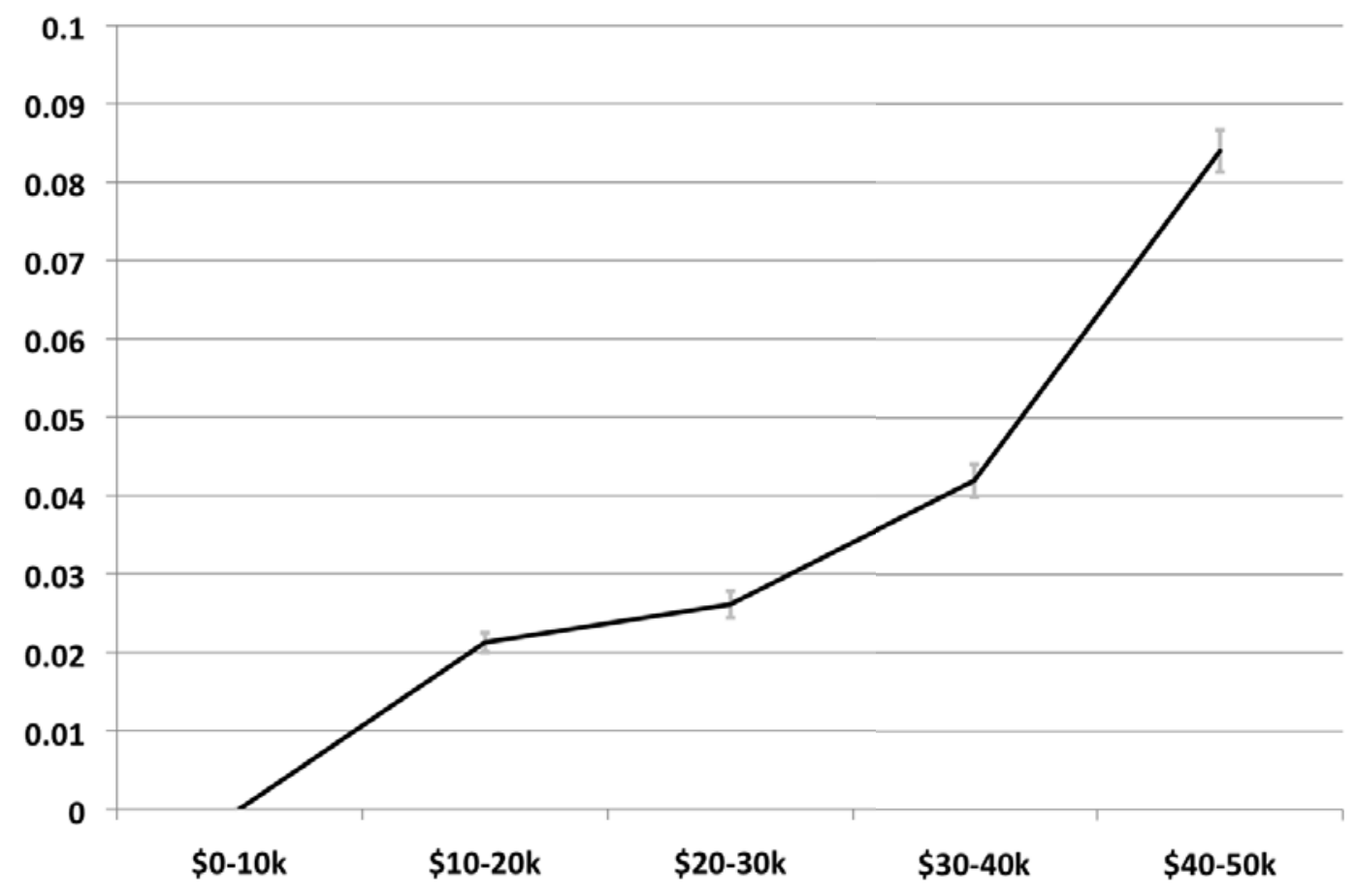


Figure 5: Relative propensity to invest over capital levels for local versus distant investors. Baseline is propensity to invest between $\$ 0-10 \mathrm{~K}$ within each group.

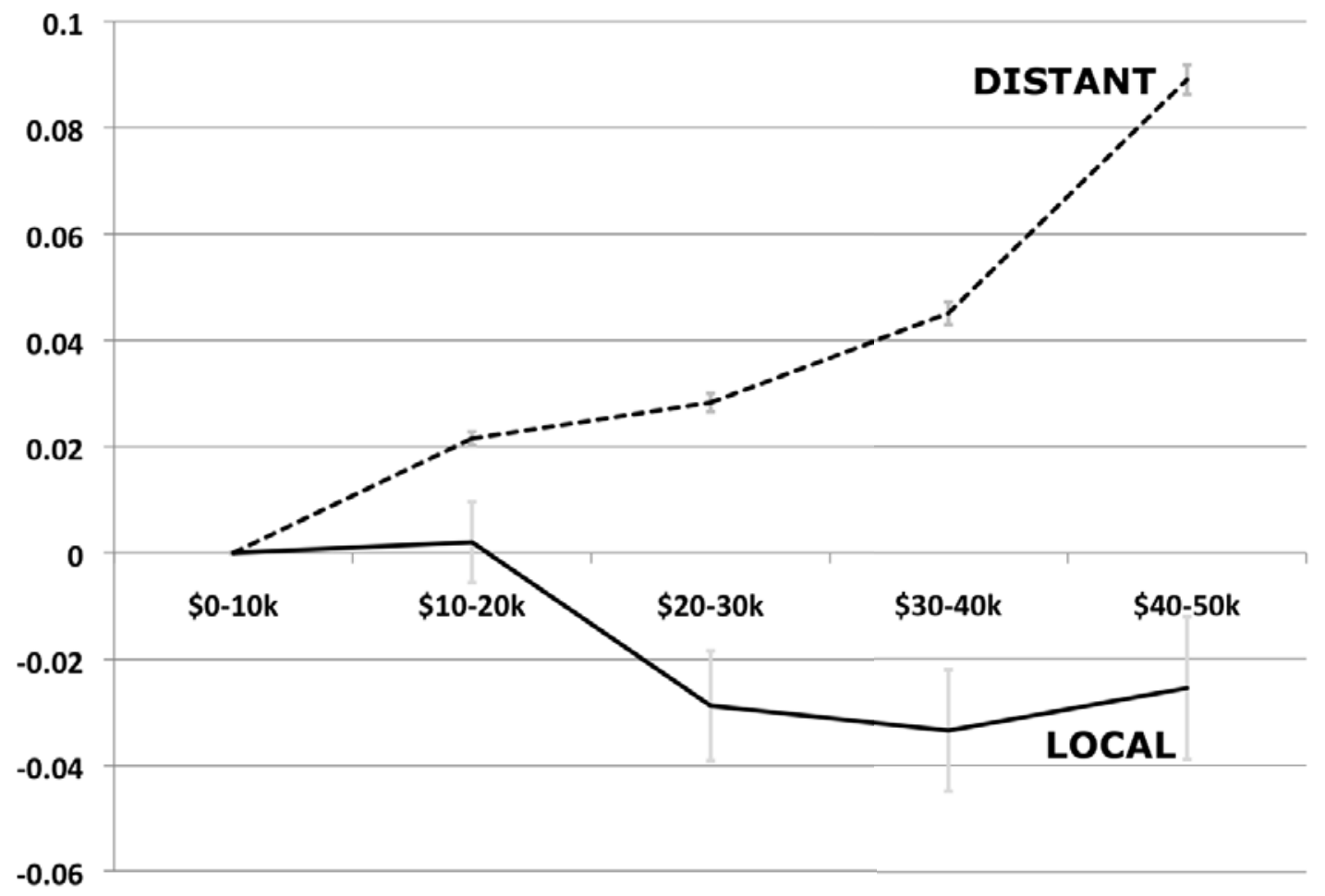


Figure 6: Relative propensity to invest over capital levels for $\mathrm{F} \& \mathrm{~F}$ versus not-F\&F investors (both local and distant). Baseline is propensity to invest between $\$ 0-10 \mathrm{~K}$ within each group.

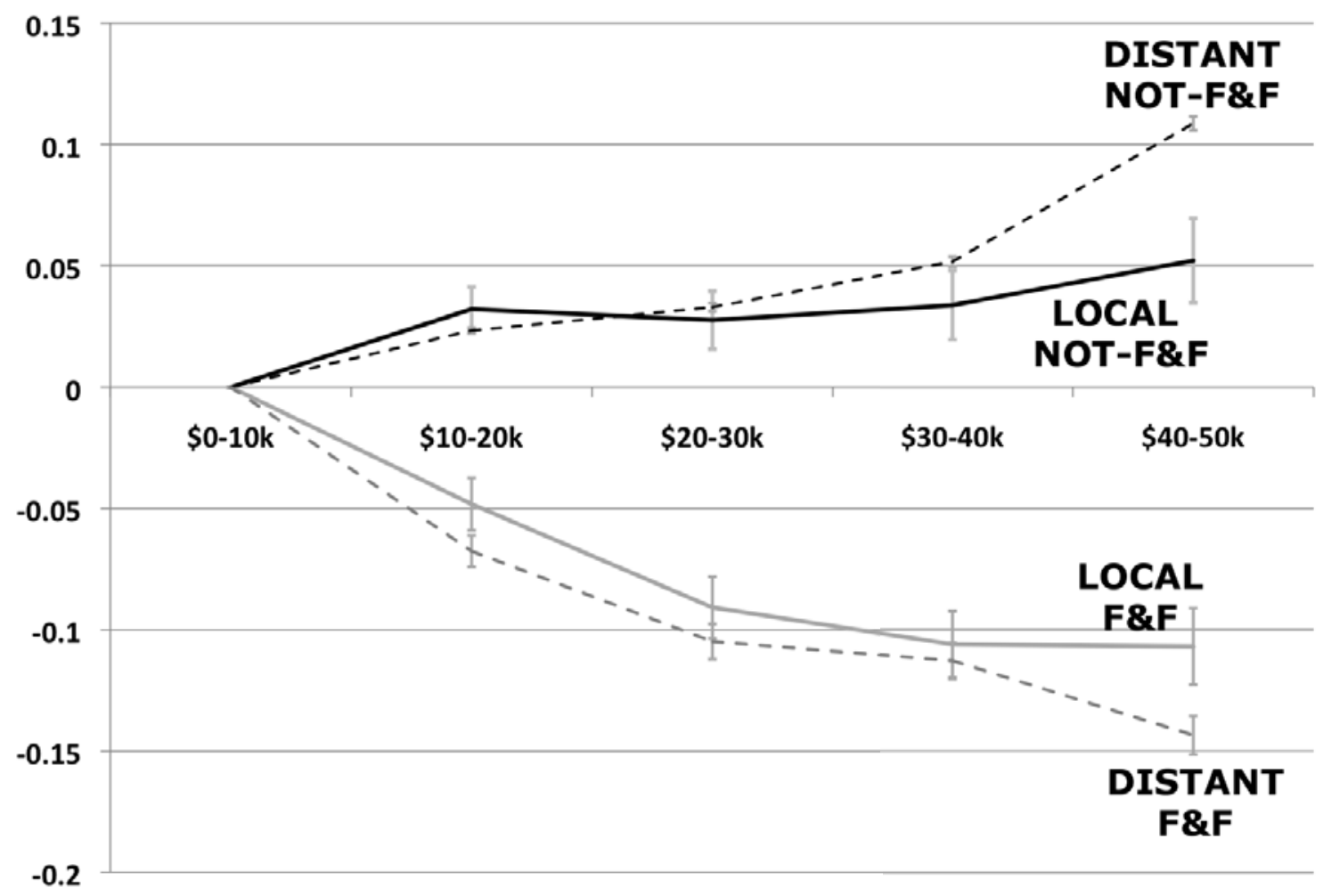




\section{Appendix}

Table A-1: $\$ 50 \mathrm{~K}$ (main) Sample

\begin{tabular}{|c|c|c|c|c|c|}
\hline VARIABLES & $\begin{array}{c}(1) \\
\text { Invest }=1\end{array}$ & $\begin{array}{c}(2) \\
\mathrm{LOCAL}\end{array}$ & $\begin{array}{c}(3) \\
\text { DISTANT }\end{array}$ & $\begin{array}{c}(4) \\
\text { LOCAL }\end{array}$ & $\begin{array}{c}(5) \\
\text { DISTANT }\end{array}$ \\
\hline$\$ 10-20 \mathrm{~K}$ accum. capital & $\begin{array}{c}0.0213^{* * *} \\
(0.0012)\end{array}$ & $\begin{array}{c}0.0020 \\
(0.0076)\end{array}$ & $\begin{array}{c}0.0215^{* * *} \\
(0.0012)\end{array}$ & $\begin{array}{c}0.0322^{* * *} \\
(0.0091)\end{array}$ & $\begin{array}{c}0.0233^{* * *} \\
(0.0012)\end{array}$ \\
\hline$\$ 20-30 \mathrm{~K}$ accum. capital & $\begin{array}{c}0.0261^{* * *} \\
(0.0017)\end{array}$ & $\begin{array}{c}-0.0287^{* * *} \\
(0.0103)\end{array}$ & $\begin{array}{c}0.0283^{* * *} \\
(0.0017)\end{array}$ & $\begin{array}{c}0.0276^{* *} \\
(0.0119)\end{array}$ & $\begin{array}{c}0.0329^{* * *} \\
(0.0017)\end{array}$ \\
\hline$\$ 30-40 \mathrm{~K}$ accum. capital & $\begin{array}{c}0.0420^{* * *} \\
(0.0021)\end{array}$ & $\begin{array}{c}-0.0334^{* * *} \\
(0.0114)\end{array}$ & $\begin{array}{c}0.0451^{* * *} * \\
(0.0021)\end{array}$ & $\begin{array}{c}0.0337^{* *} \\
(0.0143)\end{array}$ & $\begin{array}{c}0.0517^{* * *} * \\
(0.0021)\end{array}$ \\
\hline$\$ 40-50 \mathrm{~K}$ accum. capital & $\begin{array}{c}0.0840^{* * *} \\
(0.0027)\end{array}$ & $\begin{array}{c}-0.0254^{*} \\
(0.0134)\end{array}$ & $\begin{array}{c}0.0891^{* * * *} \\
(0.0028)\end{array}$ & $\begin{array}{c}0.0521^{* * * *} \\
(0.0174)\end{array}$ & $\begin{array}{c}0.1086^{* * *} \\
(0.0028)\end{array}$ \\
\hline$\$ 10-20 \mathrm{~K}$ accum. capital $*$ F\&F & & & & $\begin{array}{c}-0.0803^{* * *} \\
(0.0121)\end{array}$ & $\begin{array}{c}-0.0909 * * * \\
(0.0065)\end{array}$ \\
\hline$\$ 20-30 \mathrm{~K}$ accum. capital $* \mathrm{~F} \& \mathrm{~F}$ & & & & $\begin{array}{c}-0.1184^{* * *} \\
(0.0130)\end{array}$ & $\begin{array}{c}-0.1377^{* * *} \\
(0.0071)\end{array}$ \\
\hline$\$ 30-40 \mathrm{~K}$ accum. capital $* \mathrm{~F} \& \mathrm{~F}$ & & & & $\begin{array}{c}-0.1397^{* * *} \\
(0.0155)\end{array}$ & $\begin{array}{c}-0.1644^{* * *} \\
(0.0073)\end{array}$ \\
\hline$\$ 40-50 \mathrm{~K}$ accum. capital $*$ F\&F & & & & $\begin{array}{c}-0.1590^{* * *} \\
(0.0181)\end{array}$ & $\begin{array}{c}-0.2521^{* * *} \\
(0.0079)\end{array}$ \\
\hline Weeks on Sellaband & $\begin{array}{c}-0.0033^{* * *} \\
(0.0003)\end{array}$ & $\begin{array}{c}-0.0038^{* * *} \\
(0.0011)\end{array}$ & $\begin{array}{c}-0.0032^{* * *} \\
(0.0003)\end{array}$ & $\begin{array}{c}-0.0034^{* * *} \\
(0.0011)\end{array}$ & $\begin{array}{c}-0.0030^{* * *} \\
(0.0003)\end{array}$ \\
\hline Observations & 709,471 & 57,855 & 651,616 & 57,855 & 651,616 \\
\hline R-squared & 0.012 & 0.042 & 0.012 & 0.050 & 0.019 \\
\hline Number of group & 18,827 & 1,164 & 17,663 & 1,164 & 17,663 \\
\hline
\end{tabular}

Dependent variable is any investment in columns (1)-(5) and sample is the $\$ 50 \mathrm{~K}$ sample. All regressions include a full set of fixed effects for each entrepreneur-investor pair (differenced out) and each week. Robust standard errors clustered at the pair level in parentheses. ${ }^{* * *} \mathrm{p}<0.01$, $* * \mathrm{p}<0.05, * \mathrm{p}<0.1$ 
Table A-2: Full Sample

\begin{tabular}{|c|c|c|c|c|c|}
\hline VARIABLES & $\begin{array}{c}(1) \\
\text { Full Sample } \\
\text { Invest=1 }\end{array}$ & $\begin{array}{c}(2) \\
\text { Full Sample } \\
\text { LOCAL }\end{array}$ & $\begin{array}{c}(3) \\
\text { Full Sample } \\
\text { DISTANT }\end{array}$ & $\begin{array}{c}(4) \\
\text { Full Sample } \\
\text { LOCAL }\end{array}$ & $\begin{array}{c}(5) \\
\text { Full Sample } \\
\text { DISTANT }\end{array}$ \\
\hline$\$ 10-20 \mathrm{~K}$ accum. capital & $\begin{array}{c}0.0109^{* * *} \\
(0.001)\end{array}$ & $\begin{array}{c}-0.0075^{*} \\
(0.005)\end{array}$ & $\begin{array}{c}0.0116^{* * *} \\
(0.001)\end{array}$ & $\begin{array}{c}0.0173^{* * *} \\
(0.006)\end{array}$ & $\begin{array}{c}0.0140^{* * *} \\
(0.001)\end{array}$ \\
\hline$\$ 20-30 \mathrm{~K}$ accum. capital & $\begin{array}{c}0.0134^{* * *} \\
(0.001)\end{array}$ & $\begin{array}{c}-0.0257^{* * *} \\
(0.006)\end{array}$ & $\begin{array}{c}0.0154^{* * *} \\
(0.001)\end{array}$ & $\begin{array}{c}0.0218^{* * *} \\
(0.007)\end{array}$ & $\begin{array}{c}0.0208^{* * *} \\
(0.001)\end{array}$ \\
\hline$\$ 30-40 \mathrm{~K}$ accum. capital & $\begin{array}{c}0.0266^{* * *} \\
(0.001)\end{array}$ & $\begin{array}{c}-0.0275^{* * *} \\
(0.007)\end{array}$ & $\begin{array}{c}0.0293^{* * *} \\
(0.001)\end{array}$ & $\begin{array}{c}0.0357^{* * * *} \\
(0.011)\end{array}$ & $\begin{array}{c}0.0376^{* * *} \\
(0.002)\end{array}$ \\
\hline$\$ 40-50 \mathrm{~K}$ accum. capital & $\begin{array}{c}0.0691^{* * *} \\
(0.002)\end{array}$ & $\begin{array}{c}-0.0153^{* *} \\
(0.008)\end{array}$ & $\begin{array}{c}0.0741^{* * *} * \\
(0.002)\end{array}$ & $\begin{array}{c}0.0590^{* * * *} \\
(0.015)\end{array}$ & $\begin{array}{c}0.0952^{* * *} \\
(0.002)\end{array}$ \\
\hline$\$ 10-20 \mathrm{~K}$ accum. capital $* \mathrm{~F} \& \mathrm{~F}$ & & & & $\begin{array}{c}-0.0551^{* * * *} \\
(0.008)\end{array}$ & $\begin{array}{c}-0.0753^{* * *} \\
(0.004)\end{array}$ \\
\hline$\$ 20-30 \mathrm{~K}$ accum. capital $*$ F\&F & & & & $\begin{array}{c}-0.0905^{* * * *} \\
(0.009)\end{array}$ & $\begin{array}{c}-0.1150^{* * *} \\
(0.005)\end{array}$ \\
\hline$\$ 30-40 \mathrm{~K}$ accum. capital $*$ F\&F & & & & $\begin{array}{c}-0.1146^{* * * *} \\
(0.013)\end{array}$ & $\begin{array}{c}-0.1477^{* * *} \\
(0.005)\end{array}$ \\
\hline$\$ 40-50 \mathrm{~K}$ accum. capital $*$ F\&F & & & & $\begin{array}{c}-0.1281^{* * *} \\
(0.016)\end{array}$ & $\begin{array}{c}-0.2338^{* * *} \\
(0.006)\end{array}$ \\
\hline Weeks on Sellaband & $\begin{array}{c}-0.0032^{* * *} \\
(0.0002)\end{array}$ & $\begin{array}{c}-0.0047^{* * *} \\
(0.0008)\end{array}$ & $\begin{array}{c}-0.0030 * * * \\
(0.0003)\end{array}$ & $\begin{array}{c}-0.0046^{* * *} \\
(0.0008)\end{array}$ & $\begin{array}{c}-0.0029 * * * \\
(0.0002)\end{array}$ \\
\hline Observations & $1,175,492$ & 99,564 & $1,075,928$ & 99,564 & $1,075,928$ \\
\hline R-squared & 0.010 & 0.033 & 0.010 & 0.037 & 0.015 \\
\hline Number of group & 24,862 & 1,715 & 23,147 & 1,715 & 23,147 \\
\hline
\end{tabular}

Dependent variable is any investment in columns (1)-(5) and sample is the full sample. All regressions include a full set of fixed effects for each entrepreneur-investor pair (differenced out) and each week. Robust standard errors clustered at the pair level in parentheses. ${ }^{* * *} \mathrm{p}<0.01,{ }^{* *} \mathrm{p}<0.05,{ }^{*} \mathrm{p}<0.1$ 
Table A-3: $\$ 1 \mathrm{~K}$ Sample

\begin{tabular}{|c|c|c|c|c|c|}
\hline VARIABLES & $\begin{array}{c}(1) \\
\$ 1 \mathrm{~K} \text { Sample } \\
\text { Invest }=1\end{array}$ & $\begin{array}{c}(2) \\
\$ 1 \mathrm{~K} \text { Sample } \\
\text { LOCAL }\end{array}$ & $\begin{array}{c}(3) \\
\$ 1 \mathrm{~K} \text { Sample } \\
\text { DISTANT }\end{array}$ & $\begin{array}{c}(4) \\
\$ 1 \mathrm{~K} \text { Sample } \\
\text { LOCAL }\end{array}$ & $\begin{array}{c}(5) \\
\$ 1 \mathrm{~K} \text { Sample } \\
\text { DISTANT }\end{array}$ \\
\hline$\$ 10-20 \mathrm{~K}$ accum. capital & $\begin{array}{c}0.0108^{* * *} \\
(0.0009)\end{array}$ & $\begin{array}{l}-0.0076^{*} \\
(0.0045)\end{array}$ & $\begin{array}{c}0.0116^{* * *} \\
(0.0009)\end{array}$ & $\begin{array}{c}0.0172^{* * *} \\
(0.0061)\end{array}$ & $\begin{array}{c}0.0140^{* * *} \\
(0.0009)\end{array}$ \\
\hline$\$ 20-30 \mathrm{~K}$ accum. capital & $\begin{array}{c}0.0133^{* * *} \\
(0.0012)\end{array}$ & $\begin{array}{c}-0.0260^{* * * *} \\
(0.0058)\end{array}$ & $\begin{array}{c}0.0154^{* * *} \\
(0.0012)\end{array}$ & $\begin{array}{c}0.0215^{* * *} \\
(0.0073)\end{array}$ & $\begin{array}{c}0.0207^{* * *} \\
(0.0012)\end{array}$ \\
\hline$\$ 30-40 \mathrm{~K}$ accum. capital & $\begin{array}{c}0.0267^{* * *} \\
(0.0015)\end{array}$ & $\begin{array}{c}-0.0276^{* * * *} \\
(0.0069)\end{array}$ & $\begin{array}{c}0.0294^{* * *} \\
(0.0015)\end{array}$ & $\begin{array}{c}0.0354^{* * *} \\
(0.0113)\end{array}$ & $\begin{array}{c}0.0376^{* * *} \\
(0.0015)\end{array}$ \\
\hline$\$ 40-50 \mathrm{~K}$ accum. capital & $\begin{array}{c}0.0692^{* * *} \\
(0.0021)\end{array}$ & $\begin{array}{l}-0.0147^{*} \\
(0.0077)\end{array}$ & $\begin{array}{c}0.0741^{* * * *} \\
(0.0021)\end{array}$ & $\begin{array}{c}0.0590^{* * *} \\
(0.0147)\end{array}$ & $\begin{array}{c}0.0952^{* * *} \\
(0.0023)\end{array}$ \\
\hline$\$ 10-20 \mathrm{~K}$ accum. capital $* \mathrm{~F} \& \mathrm{~F}$ & & & & $\begin{array}{c}-0.0552^{* * *} \\
(0.0084)\end{array}$ & $\begin{array}{c}-0.0755^{* * *} \\
(0.0045)\end{array}$ \\
\hline$\$ 20-30 \mathrm{~K}$ accum. capital $* \mathrm{~F} \& \mathrm{~F}$ & & & & $\begin{array}{c}-0.0905^{* * *} \\
(0.0094)\end{array}$ & $\begin{array}{c}-0.1151^{* * *} \\
(0.0051)\end{array}$ \\
\hline$\$ 30-40 \mathrm{~K}$ accum. capital $* \mathrm{~F} \& \mathrm{~F}$ & & & & $\begin{array}{c}-0.1144^{* * *} \\
(0.0131)\end{array}$ & $\begin{array}{c}-0.1479 * * * \\
(0.0055)\end{array}$ \\
\hline$\$ 40-50 \mathrm{~K}$ accum. capital $* \mathrm{~F} \& \mathrm{~F}$ & & & & $\begin{array}{c}-0.1274^{* * *} \\
(0.0161)\end{array}$ & $\begin{array}{c}-0.2338 * * * \\
(0.0063)\end{array}$ \\
\hline Weeks on Sellaband & $\begin{array}{c}-0.0031^{* * *} \\
(0.0002)\end{array}$ & $\begin{array}{c}-0.0047^{* * * *} \\
(0.0008)\end{array}$ & $\begin{array}{c}-0.0030^{* * *} \\
(0.0003)\end{array}$ & $\begin{array}{c}-0.0046^{* * *} \\
(0.0008)\end{array}$ & $\begin{array}{c}-0.0028^{* * *} \\
(0.0002)\end{array}$ \\
\hline Observations & $1,155,845$ & 98,118 & $1,057,727$ & 98,118 & $1,057,727$ \\
\hline R-squared & 0.010 & 0.033 & 0.010 & 0.038 & 0.015 \\
\hline Number of group & 24,411 & 1,681 & 22,730 & 1,681 & 22,730 \\
\hline
\end{tabular}

Dependent variable is any investment in columns (1)-(5) and sample is the $\$ 1 \mathrm{~K}$ sample (all entrepreneurs who have raised at least $\$ 1000)$. All regressions include a full set of fixed effects for each entrepreneur-investor pair (differenced out) and each week. Robust standard errors clustered at the pair level in parentheses. ${ }^{* * *} \mathrm{p}<0.01,{ }^{* *} \mathrm{p}<0.05,{ }^{*} \mathrm{p}<0.1$ 
Table A-4: $\$ 5 \mathrm{~K}$ Sample

\begin{tabular}{|c|c|c|c|c|c|}
\hline VARIABLES & $\begin{array}{c}(1) \\
\$ 5 \mathrm{~K} \text { Sample } \\
\text { Invest }=1\end{array}$ & $\begin{array}{c}(2) \\
\$ 5 \mathrm{~K} \text { Sample } \\
\text { LOCAL }\end{array}$ & $\begin{array}{c}(3) \\
\$ 5 K \text { Sample } \\
\text { DISTANT }\end{array}$ & $\begin{array}{c}(4) \\
\$ 5 \mathrm{~K} \text { Sample } \\
\text { LOCAL }\end{array}$ & $\begin{array}{c}(5) \\
\$ 5 K \text { Sample } \\
\text { DISTANT }\end{array}$ \\
\hline$\$ 10-20 \mathrm{~K}$ accum. capital & $\begin{array}{c}0.0114^{* * *} \\
(0.0009)\end{array}$ & $\begin{array}{l}-0.0087^{*} \\
(0.0045)\end{array}$ & $\begin{array}{c}0.0121^{* * *} \\
(0.0009)\end{array}$ & $\begin{array}{c}0.0160^{* * *} \\
(0.0061)\end{array}$ & $\begin{array}{c}0.0144^{* * *} \\
(0.0009)\end{array}$ \\
\hline$\$ 20-30 \mathrm{~K}$ accum. capital & $\begin{array}{c}0.0141^{* * *} \\
(0.0012)\end{array}$ & $\begin{array}{c}-0.0286^{* * *} \\
(0.0059)\end{array}$ & $\begin{array}{c}0.0162^{* * *} \\
(0.0012)\end{array}$ & $\begin{array}{c}0.0190^{* *} \\
(0.0074)\end{array}$ & $\begin{array}{c}0.0214^{* * *} \\
(0.0012)\end{array}$ \\
\hline$\$ 30-40 \mathrm{~K}$ accum. capital & $\begin{array}{c}0.0279^{* * *} \\
(0.0015)\end{array}$ & $\begin{array}{c}-0.0302^{* * *} \\
(0.0071)\end{array}$ & $\begin{array}{c}0.0307^{* * *} \\
(0.0016)\end{array}$ & $\begin{array}{c}0.0328^{* * * *} \\
(0.0114)\end{array}$ & $\begin{array}{c}0.0387^{* * *} \\
(0.0016)\end{array}$ \\
\hline$\$ 40-50 \mathrm{~K}$ accum. capital & $\begin{array}{c}0.0705^{* * *} \\
(0.0021)\end{array}$ & $\begin{array}{c}-0.0171^{* *} \\
(0.0080)\end{array}$ & $\begin{array}{c}0.0755^{* * *} \\
(0.0022)\end{array}$ & $\begin{array}{c}0.0561^{* * *} \\
(0.0148)\end{array}$ & $\begin{array}{c}0.0963^{* * *} \\
(0.0023)\end{array}$ \\
\hline$\$ 10-20 \mathrm{~K}$ accum. capital $* \mathrm{~F} \& \mathrm{~F}$ & & & & $\begin{array}{c}-0.0551^{* * *} \\
(0.0084)\end{array}$ & $\begin{array}{c}-0.0756^{* * *} \\
(0.0045)\end{array}$ \\
\hline$\$ 20-30 \mathrm{~K}$ accum. capital $* \mathrm{~F} \& \mathrm{~F}$ & & & & $\begin{array}{c}-0.0909^{* * * *} \\
(0.0094)\end{array}$ & $\begin{array}{c}-0.1150^{* * *} \\
(0.0051)\end{array}$ \\
\hline$\$ 30-40 \mathrm{~K}$ accum. capital $* \mathrm{~F} \& \mathrm{~F}$ & & & & $\begin{array}{c}-0.1148^{* * * *} \\
(0.0130)\end{array}$ & $\begin{array}{c}-0.1477^{* * *} \\
(0.0055)\end{array}$ \\
\hline$\$ 40-50 \mathrm{~K}$ accum. capital $* \mathrm{~F} \& \mathrm{~F}$ & & & & $\begin{array}{c}-0.1276 * * * \\
(0.0161)\end{array}$ & $\begin{array}{c}-0.2338^{* * *} \\
(0.0063)\end{array}$ \\
\hline Weeks on Sellaband & $\begin{array}{c}-0.0032^{* * *} \\
(0.0002)\end{array}$ & $\begin{array}{c}-0.0046 * * * \\
(0.0008)\end{array}$ & $\begin{array}{c}-0.0030^{* * * *} \\
(0.0003)\end{array}$ & $\begin{array}{c}-0.0045^{* * *} \\
(0.0008)\end{array}$ & $\begin{array}{c}-0.0029 * * * \\
(0.0002)\end{array}$ \\
\hline Observations & $1,070,501$ & 89,276 & 981,225 & 89,276 & 981,225 \\
\hline R-squared & 0.011 & 0.035 & 0.011 & 0.040 & 0.016 \\
\hline Number of group & 23,269 & 1,544 & 21,725 & 1,544 & 21,725 \\
\hline
\end{tabular}

Dependent variable is any investment in columns (1)-(5) and sample is the $\$ 5 \mathrm{~K}$ sample (all entrepreneurs who have raised at least $\$ 5000)$. All regressions include a full set of fixed effects for each entrepreneur-investor pair (differenced out) and each week. Robust standard errors clustered at the pair level in parentheses. ${ }^{* * *} \mathrm{p}<0.01,{ }^{* *} \mathrm{p}<0.05,{ }^{*} \mathrm{p}<0.1$ 
Table A-5: No entrepreneurs from Holland

\begin{tabular}{|c|c|c|c|c|c|}
\hline VARIABLES & $\begin{array}{c}(1) \\
\text { Invest =1 }\end{array}$ & $\begin{array}{c}(2) \\
\text { LOCAL }\end{array}$ & $\begin{array}{c}(3) \\
\text { DISTANT }\end{array}$ & $\begin{array}{c}(4) \\
\text { LOCAL }\end{array}$ & $\begin{array}{c}(5) \\
\text { DISTANT }\end{array}$ \\
\hline$\$ 10-20 \mathrm{~K}$ accum. capital & $\begin{array}{c}0.0244^{* * *} \\
(0.0013)\end{array}$ & $\begin{array}{l}-0.0150 \\
(0.0131)\end{array}$ & $\begin{array}{c}0.0251^{* * * *} \\
(0.0013)\end{array}$ & $\begin{array}{c}0.0133 \\
(0.0157)\end{array}$ & $\begin{array}{c}0.0270^{* * *} \\
(0.0013)\end{array}$ \\
\hline$\$ 20-30 \mathrm{~K}$ accum. capital & $\begin{array}{c}0.0285^{* * *} \\
(0.0018)\end{array}$ & $\begin{array}{c}-0.0634^{* * *} \\
(0.0157)\end{array}$ & $\begin{array}{c}0.0312^{* * *} \\
(0.0018)\end{array}$ & $\begin{array}{c}0.0018 \\
(0.0187)\end{array}$ & $\begin{array}{c}0.0349^{* * *} \\
(0.0018)\end{array}$ \\
\hline$\$ 30-40 \mathrm{~K}$ accum. capital & $\begin{array}{c}0.0458^{* * * *} \\
(0.0023)\end{array}$ & $\begin{array}{c}-0.0726^{* * *} \\
(0.0186)\end{array}$ & $\begin{array}{c}0.0499^{* * *} \\
(0.0023)\end{array}$ & $\begin{array}{c}0.0116 \\
(0.0234)\end{array}$ & $\begin{array}{c}0.0564^{* * *} \\
(0.0023)\end{array}$ \\
\hline$\$ 40-50 \mathrm{~K}$ accum. capital & $\begin{array}{c}0.0885 * * * \\
(0.0029)\end{array}$ & $\begin{array}{c}-0.0720^{* * *} \\
(0.0194)\end{array}$ & $\begin{array}{c}0.0944^{* * *} \\
(0.0030)\end{array}$ & $\begin{array}{c}0.0230 \\
(0.0257)\end{array}$ & $\begin{array}{c}0.1128^{* * *} \\
(0.0030)\end{array}$ \\
\hline$\$ 10-20 \mathrm{~K}$ accum. capital $*$ F\&F & & & & $\begin{array}{c}-0.0938^{* * *} \\
(0.0220)\end{array}$ & $\begin{array}{c}-0.0960^{* * *} \\
(0.0073)\end{array}$ \\
\hline$\$ 20-30 \mathrm{~K}$ accum. capital $*$ F\&F & & & & $\begin{array}{c}-0.1521^{* * *} \\
(0.0228)\end{array}$ & $\begin{array}{c}-0.1382^{* * *} \\
(0.0081)\end{array}$ \\
\hline$\$ 30-40 \mathrm{~K}$ accum. capital $*$ F\&F & & & & $\begin{array}{c}-0.1853^{* * *} \\
(0.0264)\end{array}$ & $\begin{array}{c}-0.1698^{* * *} \\
(0.0082)\end{array}$ \\
\hline$\$ 40-50 \mathrm{~K}$ accum. capital $*$ F\&F & & & & $\begin{array}{c}-0.2032^{* * *} \\
(0.0294)\end{array}$ & $\begin{array}{c}-0.2633^{* * *} \\
(0.0091)\end{array}$ \\
\hline Weeks on Sellaband & $\begin{array}{c}-0.0005^{* *} \\
(0.0002)\end{array}$ & $\begin{array}{c}-0.0031^{*} \\
(0.0018)\end{array}$ & $\begin{array}{c}-0.0005^{* *} \\
(0.0002)\end{array}$ & $\begin{array}{c}-0.0029^{*} \\
(0.0018)\end{array}$ & $\begin{array}{c}-0.0006^{* * *} \\
(0.0002)\end{array}$ \\
\hline Observations & 558,150 & 20,841 & 537,309 & 20,841 & 537,309 \\
\hline R-squared & 0.011 & 0.039 & 0.012 & 0.050 & 0.018 \\
\hline Number of group & 16,372 & 663 & 15,709 & 663 & 15,709 \\
\hline
\end{tabular}

Dependent variable is any investment in columns (1)-(5) and sample is the $\$ 50 \mathrm{~K}$ sample without entrepreneurs from Holland. All regressions include a full set of fixed effects for each entrepreneur-investor pair (differenced out) and each week. Robust standard errors clustered at the pair level in parentheses. ${ }^{* * *} \mathrm{p}<0.01,{ }^{* *} \mathrm{p}<0.05,{ }^{*} \mathrm{p}<0.1$ 
Table A-6: No entrepreneurs from music hubs (NYC, LA, Nashville, London, or Paris)

\begin{tabular}{|c|c|c|c|c|c|}
\hline VARIABLES & $\begin{array}{c}(1) \\
\text { Invest }=1\end{array}$ & $\begin{array}{c}(2) \\
\text { LOCAL }\end{array}$ & $\begin{array}{c}(3) \\
\text { DISTANT }\end{array}$ & $\begin{array}{c}(4) \\
\text { LOCAL }\end{array}$ & $\begin{array}{c}(5) \\
\text { DISTANT }\end{array}$ \\
\hline \$10-20K accum. capital & $\begin{array}{c}0.0195^{* * *} \\
(0.0014)\end{array}$ & $\begin{array}{c}0.0121 \\
(0.0088)\end{array}$ & $\begin{array}{c}0.0188^{* * *} \\
(0.0014)\end{array}$ & $\begin{array}{c}0.0405^{* * *} \\
(0.0108)\end{array}$ & $\begin{array}{c}0.0198^{* * * *} \\
(0.0014)\end{array}$ \\
\hline$\$ 20-30 \mathrm{~K}$ accum. capital & $\begin{array}{c}0.0314^{* * *} \\
(0.0021)\end{array}$ & $\begin{array}{l}-0.0170 \\
(0.0147)\end{array}$ & $\begin{array}{c}0.0335^{* * *} \\
(0.0022)\end{array}$ & $\begin{array}{c}0.0339^{* *} \\
(0.0168)\end{array}$ & $\begin{array}{c}0.0358^{* * *} \\
(0.0021)\end{array}$ \\
\hline$\$ 30-40 \mathrm{~K}$ accum. capital & $\begin{array}{c}0.0451^{* * *} \\
(0.0025)\end{array}$ & $\begin{array}{l}-0.0248 \\
(0.0154)\end{array}$ & $\begin{array}{c}0.0477^{* * *} \\
(0.0026)\end{array}$ & $\begin{array}{l}0.0314^{*} \\
(0.0184)\end{array}$ & $\begin{array}{c}0.0525^{* * *} \\
(0.0026)\end{array}$ \\
\hline$\$ 40-50 \mathrm{~K}$ accum. capital & $\begin{array}{c}0.0969^{* * *} \\
(0.0034)\end{array}$ & $\begin{array}{l}-0.0204 \\
(0.0204)\end{array}$ & $\begin{array}{c}0.1022^{* * *} \\
(0.0035)\end{array}$ & $\begin{array}{l}0.0460^{*} \\
(0.0238)\end{array}$ & $\begin{array}{c}0.1191^{* * *} \\
(0.0036)\end{array}$ \\
\hline$\$ 10-20 \mathrm{~K}$ accum. capital $*$ F\&F & & & & $\begin{array}{c}-0.0693^{* * *} \\
(0.0131)\end{array}$ & $\begin{array}{c}-0.0592 * * * \\
(0.0069)\end{array}$ \\
\hline$\$ 20-30 \mathrm{~K}$ accum. capital $* \mathrm{~F} \& \mathrm{~F}$ & & & & $\begin{array}{c}-0.1033^{* * *} \\
(0.0138)\end{array}$ & $\begin{array}{c}-0.1017^{* * * *} \\
(0.0082)\end{array}$ \\
\hline$\$ 30-40 \mathrm{~K}$ accum. capital $*$ F\&F & & & & $\begin{array}{c}-0.1181^{* * * *} \\
(0.0168)\end{array}$ & $\begin{array}{c}-0.1551^{* * *} \\
(0.0091)\end{array}$ \\
\hline$\$ 40-50 \mathrm{~K}$ accum. capital $*$ F\&F & & & & $\begin{array}{c}-0.1409 * * * \\
(0.0209)\end{array}$ & $\begin{array}{c}-0.2400^{* * * *} \\
(0.0097)\end{array}$ \\
\hline Weeks on Sellaband & $\begin{array}{c}-0.0045^{* * *} \\
(0.0003)\end{array}$ & $\begin{array}{c}-0.0049^{* * *} \\
(0.0013)\end{array}$ & $\begin{array}{c}-0.0045^{* * *} \\
(0.0004)\end{array}$ & $\begin{array}{c}-0.0045^{* * *} \\
(0.0014)\end{array}$ & $\begin{array}{c}-0.0042^{* * *} \\
(0.0004)\end{array}$ \\
\hline Observations & 482,683 & 44,928 & 437,755 & 44,928 & 437,755 \\
\hline R-squared & 0.013 & 0.043 & 0.014 & 0.049 & 0.020 \\
\hline Number of group & 12,310 & 796 & 11,514 & 796 & 11,514 \\
\hline
\end{tabular}

Dependent variable is any investment in columns (1)-(5) and sample is the $\$ 50 \mathrm{~K}$ sample without entrepreneurs from music hubs (New York, Los Angeles, Nashville, London, or Paris). All regressions include a full set of fixed effects for each entrepreneur-investor pair (differenced out) and each week. Robust standard errors clustered at the pair level in parentheses. $* * *$ $\mathrm{p}<0.01,{ }^{* *} \mathrm{p}<0.05,{ }^{*} \mathrm{p}<0.1$ 
Table A-7: No entrepreneurs from music hubs (NYC, LA, Nashville, London, or Paris) and controlling for live shows

\begin{tabular}{|c|c|c|c|c|c|}
\hline VARIABLES & $\begin{array}{c}(1) \\
\text { Invest =1 }\end{array}$ & $\begin{array}{c}(2) \\
\text { LOCAL }\end{array}$ & $\begin{array}{c}(3) \\
\text { DISTANT }\end{array}$ & $\begin{array}{c}(4) \\
\text { LOCAL }\end{array}$ & $\begin{array}{c}(5) \\
\text { DISTANT }\end{array}$ \\
\hline$\$ 10-20 \mathrm{~K}$ accum. capital & $\begin{array}{c}0.0183^{* * *} \\
(0.0014)\end{array}$ & $\begin{array}{c}0.0123 \\
(0.0088)\end{array}$ & $\begin{array}{c}0.0175^{* * *} \\
(0.0014)\end{array}$ & $\begin{array}{c}0.0371^{* * *} \\
(0.0108)\end{array}$ & $\begin{array}{c}0.0184^{* * *} \\
(0.0014)\end{array}$ \\
\hline$\$ 20-30 \mathrm{~K}$ accum. capital & $\begin{array}{c}0.0334^{* * *} \\
(0.0021)\end{array}$ & $\begin{array}{l}-0.0188 \\
(0.0146)\end{array}$ & $\begin{array}{c}0.0355^{* * *} \\
(0.0022)\end{array}$ & $\begin{array}{l}0.0287^{*} \\
(0.0168)\end{array}$ & $\begin{array}{c}0.0374^{* * *} \\
(0.0021)\end{array}$ \\
\hline$\$ 30-40 \mathrm{~K}$ accum. capital & $\begin{array}{c}0.0475^{* * *} \\
(0.0025)\end{array}$ & $\begin{array}{c}-0.0274^{*} \\
(0.0153)\end{array}$ & $\begin{array}{c}0.0501^{* * *} \\
(0.0026)\end{array}$ & $\begin{array}{c}0.0252 \\
(0.0183)\end{array}$ & $\begin{array}{c}0.0544^{* * *} * \\
(0.0026)\end{array}$ \\
\hline$\$ 40-50 \mathrm{~K}$ accum. capital & $\begin{array}{c}0.1006^{* * *} \\
(0.0034)\end{array}$ & $\begin{array}{l}-0.0222 \\
(0.0202)\end{array}$ & $\begin{array}{c}0.1060^{* * *} \\
(0.0035)\end{array}$ & $\begin{array}{l}0.0404^{*} \\
(0.0237)\end{array}$ & $\begin{array}{c}0.1223^{* * *} \\
(0.0036)\end{array}$ \\
\hline$\$ 10-20 \mathrm{~K}$ accum. capital $*$ F\&F & & & & $\begin{array}{c}-0.0618^{* * *} \\
(0.0130)\end{array}$ & $\begin{array}{c}-0.0553^{* * *} \\
(0.0070)\end{array}$ \\
\hline$\$ 20-30 \mathrm{~K}$ accum. capital $*$ F\&F & & & & $\begin{array}{c}-0.0966^{* * *} \\
(0.0136)\end{array}$ & $\begin{array}{c}-0.0931 * * * \\
(0.0081)\end{array}$ \\
\hline$\$ 30-40 \mathrm{~K}$ accum. capital $*$ F\&F & & & & $\begin{array}{c}-0.1116^{* * *} \\
(0.0166)\end{array}$ & $\begin{array}{c}-0.1450^{* * *} \\
(0.0090)\end{array}$ \\
\hline$\$ 40-50 \mathrm{~K}$ accum. capital $* \mathrm{~F} \& \mathrm{~F}$ & & & & $\begin{array}{c}-0.1335^{* * *} \\
(0.0208)\end{array}$ & $\begin{array}{c}-0.2307^{* * *} * \\
(0.0096)\end{array}$ \\
\hline Weeks on Sellaband & $\begin{array}{c}-0.0023^{* * *} \\
(0.0003)\end{array}$ & $\begin{array}{c}-0.0014 \\
(0.0013)\end{array}$ & $\begin{array}{c}-0.0023^{* * *} \\
(0.0003)\end{array}$ & $\begin{array}{l}-0.0010 \\
(0.0014)\end{array}$ & $\begin{array}{c}-0.0020^{* * *} \\
(0.0003)\end{array}$ \\
\hline Videos uploaded (lagged) & $\begin{array}{c}0.0019 \\
(0.0053)\end{array}$ & $\begin{array}{c}0.1633^{* * *} * \\
(0.0593)\end{array}$ & $\begin{array}{l}-0.0029 \\
(0.0051)\end{array}$ & $\begin{array}{c}0.1670^{* * *} \\
(0.0579)\end{array}$ & $\begin{array}{l}-0.0021 \\
(0.0051)\end{array}$ \\
\hline loaded (lagged) & $\begin{array}{l}-0.0009 \\
(0.0009)\end{array}$ & $\begin{array}{l}-0.0020 \\
(0.0032)\end{array}$ & $\begin{array}{l}-0.0008 \\
(0.0010)\end{array}$ & $\begin{array}{l}-0.0013 \\
(0.0032)\end{array}$ & $\begin{array}{l}-0.0013 \\
(0.0010)\end{array}$ \\
\hline Investor proximate to Live Show & $\begin{array}{l}0.0124^{*} \\
(0.0068)\end{array}$ & $\begin{array}{c}0.0365^{* * *} \\
(0.0140)\end{array}$ & $\begin{array}{c}-0.0052 \\
(0.0204)\end{array}$ & $\begin{array}{c}0.0378^{* * *} \\
(0.0139)\end{array}$ & $\begin{array}{l}-0.0027 \\
(0.0202)\end{array}$ \\
\hline & 478 & 44,815 & 433 & 44,815 & 433,436 \\
\hline & & 0.0 & & 0.046 & \\
\hline Number of group & 12,310 & 796 & 11,514 & 796 & 11,514 \\
\hline
\end{tabular}

Dependent variable is any investment in columns (1)-(5) and sample is the $\$ 50 \mathrm{~K}$ sample without entrepreneurs from music hubs (New York, Los Angeles, Nashville, London, or Paris). Controls for videos and songs uploaded by the entrepreneurs, as well as live shows proximate to the investor are included. All regressions include a full set of fixed effects for each entrepreneur-investor pair (differenced out) and each week. Robust standard errors clustered at the pair level in parentheses. ${ }^{* * *} \mathrm{p}<0.01,{ }^{* *} \mathrm{p}<0.05,{ }^{*} \mathrm{p}<0.1$ 
Table A-8: Only investors who invest two or more times.

\begin{tabular}{|c|c|c|c|c|c|}
\hline VARIABLES & $\begin{array}{c}(1) \\
\text { Invest }=1\end{array}$ & $\begin{array}{c}(2) \\
\text { LOCAL }\end{array}$ & $\begin{array}{c}(3) \\
\text { DISTANT }\end{array}$ & $\begin{array}{c}(4) \\
\text { LOCAL }\end{array}$ & $\begin{array}{c}(5) \\
\text { DISTANT }\end{array}$ \\
\hline$\$ 10-20 \mathrm{~K}$ accum. capital & $\begin{array}{c}0.0235^{* * *} \\
(0.0013)\end{array}$ & $\begin{array}{c}0.0030 \\
(0.0130)\end{array}$ & $\begin{array}{c}0.0239 * * * \\
(0.0013)\end{array}$ & $\begin{array}{c}0.0068 \\
(0.0127)\end{array}$ & $\begin{array}{c}0.0242^{* * * *} \\
(0.0013)\end{array}$ \\
\hline \$20-30K accum. capital & $\begin{array}{c}0.0362^{* * *} \\
(0.0018)\end{array}$ & $\begin{array}{l}-0.0048 \\
(0.0204)\end{array}$ & $\begin{array}{c}0.0368^{* * *} \\
(0.0018)\end{array}$ & $\begin{array}{c}0.0052 \\
(0.0201)\end{array}$ & $\begin{array}{c}0.0374^{* * *} \\
(0.0018)\end{array}$ \\
\hline \$30-40K accum. capital & $\begin{array}{c}0.0581^{* * *} \\
(0.0022)\end{array}$ & $\begin{array}{c}0.0114 \\
(0.0229)\end{array}$ & $\begin{array}{c}0.0590 * * * \\
(0.0022)\end{array}$ & $\begin{array}{c}0.0254 \\
(0.0228)\end{array}$ & $\begin{array}{c}0.0598^{* * *} \\
(0.0022)\end{array}$ \\
\hline \$40-50K accum. capital & $\begin{array}{c}0.1154^{* * *} \\
(0.0029)\end{array}$ & $\begin{array}{c}0.0327 \\
(0.0264)\end{array}$ & $\begin{array}{c}0.1171^{* * *} \\
(0.0029)\end{array}$ & $\begin{array}{l}0.0464^{*} \\
(0.0268)\end{array}$ & $\begin{array}{c}0.1188^{* * *} \\
(0.0029)\end{array}$ \\
\hline$\$ 10-20 \mathrm{~K}$ accum. capital $*$ F\&F & & & & $\begin{array}{c}-0.0353 \\
(0.0479)\end{array}$ & $\begin{array}{c}-0.0757^{* * * *} \\
(0.0165)\end{array}$ \\
\hline$\$ 20-30 \mathrm{~K}$ accum. capital $*$ F\&F & & & & $\begin{array}{c}-0.0852 \\
(0.0546)\end{array}$ & $\begin{array}{c}-0.1071^{* * *} \\
(0.0203)\end{array}$ \\
\hline$\$ 30-40 \mathrm{~K}$ accum. capital $*$ F\&F & & & & $\begin{array}{c}-0.1081^{* *} \\
(0.0489)\end{array}$ & $\begin{array}{c}-0.1351^{* * * *} \\
(0.0210)\end{array}$ \\
\hline$\$ 40-50 \mathrm{~K}$ accum. capital $*$ F\&F & & & & $\begin{array}{c}-0.1007^{*} \\
(0.0600)\end{array}$ & $\begin{array}{c}-0.2007^{* * *} \\
(0.0242)\end{array}$ \\
\hline Weeks on Sellaband & $\begin{array}{c}-0.0024^{* * *} \\
(0.0003)\end{array}$ & $\begin{array}{l}-0.0016 \\
(0.0011)\end{array}$ & $\begin{array}{c}-0.0025^{* * *} * \\
(0.0003)\end{array}$ & $\begin{array}{l}-0.0017 \\
(0.0011)\end{array}$ & $\begin{array}{c}-0.0024^{* * *} \\
(0.0003)\end{array}$ \\
\hline Observations & 585,803 & 16,900 & 568,903 & 16,900 & 568,903 \\
\hline R-squared & 0.014 & 0.022 & 0.015 & 0.023 & 0.015 \\
\hline Number of group & 14,790 & 374 & 14,416 & 374 & 14,416 \\
\hline
\end{tabular}

Dependent variable is any investment in columns (1)-(5) and sample is the $\$ 50 \mathrm{~K}$ sample where only investors who invest at least two or more times are included. All regressions include a full set of fixed effects for each entrepreneur-investor pair (differenced out) and each week. Robust standard errors clustered at the pair level in parentheses. ${ }^{* * *} \mathrm{p}<0.01$, ** $\mathrm{p}<0.05,{ }^{*} \mathrm{p}<0.1$ 
Table A-9: Entrepreneur-Investor-Month as a unit of analysis.

\begin{tabular}{|c|c|c|c|c|c|}
\hline VARIABLES & $\begin{array}{c}(1) \\
\text { Invest }=1\end{array}$ & $\begin{array}{c}(2) \\
\text { LOCAL }\end{array}$ & $\begin{array}{c}(3) \\
\text { DISTANT }\end{array}$ & $\begin{array}{c}(4) \\
\text { LOCAL }\end{array}$ & $\begin{array}{c}(5) \\
\text { DISTANT }\end{array}$ \\
\hline$\$ 10-20 \mathrm{~K}$ accum. capital & $\begin{array}{c}0.0556^{* * *} \\
(0.0032)\end{array}$ & $\begin{array}{c}0.0054 \\
(0.0183)\end{array}$ & $\begin{array}{c}0.0539^{* * *} \\
(0.0033)\end{array}$ & $\begin{array}{c}0.0823^{* * *} \\
(0.0214)\end{array}$ & $\begin{array}{c}0.0571^{* * *} \\
(0.0033)\end{array}$ \\
\hline$\$ 20-30 \mathrm{~K}$ accum. capital & $\begin{array}{c}0.0682^{* * *} \\
(0.0043)\end{array}$ & $\begin{array}{c}-0.1062^{* * *} \\
(0.0235)\end{array}$ & $\begin{array}{c}0.0745^{* * *} \\
(0.0043)\end{array}$ & $\begin{array}{l}0.0503^{*} \\
(0.0271)\end{array}$ & $\begin{array}{c}0.0885^{* * *} \\
(0.0043)\end{array}$ \\
\hline$\$ 30-40 \mathrm{~K}$ accum. capital & $\begin{array}{c}0.1373^{* * *} \\
(0.0053)\end{array}$ & $\begin{array}{c}-0.0821^{* * *} \\
(0.0263)\end{array}$ & $\begin{array}{c}0.1440 * * * \\
(0.0055)\end{array}$ & $\begin{array}{c}0.1059 * * * \\
(0.0322)\end{array}$ & $\begin{array}{c}0.1707^{* * *} \\
(0.0054)\end{array}$ \\
\hline$\$ 40-50 \mathrm{~K}$ accum. capital & $\begin{array}{c}0.1180^{* * *} \\
(0.0064)\end{array}$ & $\begin{array}{c}-0.1225^{* * *} \\
(0.0299)\end{array}$ & $\begin{array}{c}0.1257^{* * *} \\
(0.0066)\end{array}$ & $\begin{array}{c}0.0588 \\
(0.0403)\end{array}$ & $\begin{array}{c}0.1618^{* * *} \\
(0.0066)\end{array}$ \\
\hline$\$ 10-20 \mathrm{k}$ accum. capital $*$ F\&F & & & & $\begin{array}{c}-0.2038^{* * *} \\
(0.0280)\end{array}$ & $\begin{array}{c}-0.2334^{* * *} \\
(0.0153)\end{array}$ \\
\hline$\$ 20-30 \mathrm{k}$ accum. capital $*$ F\&F & & & & $\begin{array}{c}-0.3174^{* * *} \\
(0.0296)\end{array}$ & $\begin{array}{c}-0.3916^{* * *} \\
(0.0169)\end{array}$ \\
\hline$\$ 30-40 \mathrm{k}$ accum. capital $*$ F\&F & & & & $\begin{array}{c}-0.3818^{* * *} \\
(0.0356)\end{array}$ & $\begin{array}{c}-0.5163^{* * *} \\
(0.0172)\end{array}$ \\
\hline$\$ 40-50 \mathrm{k}$ accum. capital $*$ F\&F & & & & $\begin{array}{c}-0.3833^{* * *} \\
(0.0416)\end{array}$ & $\begin{array}{c}-0.5725^{* * *} \\
(0.0191)\end{array}$ \\
\hline Weeks on Sellaband & $\begin{array}{c}0.0191 * * * \\
(0.0024)\end{array}$ & $\begin{array}{c}0.0377^{* * *} \\
(0.0089)\end{array}$ & $\begin{array}{c}0.0188^{* * *} \\
(0.0025)\end{array}$ & $\begin{array}{c}0.0360^{* * *} \\
(0.0093)\end{array}$ & $\begin{array}{c}0.0216^{* * *} \\
(0.0025)\end{array}$ \\
\hline Observations & 192,030 & 15,242 & 176,788 & 15,242 & 176,788 \\
\hline R-squared & 0.020 & 0.120 & 0.020 & 0.145 & 0.038 \\
\hline Number of group & 18,827 & 1,164 & 17,663 & 1,164 & 17,663 \\
\hline
\end{tabular}

Dependent variable is any investment in columns (1)-(5) and sample is the $\$ 50 \mathrm{~K}$ sample. Unit of analysis is the entrepreneur-investor-month. All regressions include a full set of fixed effects for each entrepreneur-investor pair (differenced out) and each month. Robust standard errors clustered at the pair level in parentheses. ${ }^{* * *} \mathrm{p}<0.01,{ }^{* *} \mathrm{p}<0.05,{ }^{*} \mathrm{p}<0.1$ 
Table A-10: Overall charts rather than cumulative investment

\begin{tabular}{lccccc}
\hline & $(1)$ & $(2)$ & $(3)$ & $(4)$ & $(5)$ \\
VARIABLES & Invest $=1$ & LOCAL & DISTANT & LOCAL & DISTANT \\
\hline Entrepreneur in overall charts (lagged) & $0.0161^{* * *}$ & $-0.0161^{* * *}$ & $0.0180^{* * *}$ & -0.0009 & $0.0210^{* * *}$ \\
& $(0.0010)$ & $(0.0043)$ & $(0.0011)$ & $(0.0066)$ & $(0.0011)$ \\
Entrepreneur in overall charts * FFF & & & & $-0.0260^{* * *}$ & $-0.0321^{* * *}$ \\
& & & & $(0.0075)$ & $(0.0027)$ \\
& & & & & \\
Weeks on Sellaband & $-0.0009^{* * *}$ & $-0.0021^{* *}$ & $-0.0007^{* * *}$ & $-0.0021^{* *}$ & $-0.0008^{* * *}$ \\
& $(0.0002)$ & $(0.0010)$ & $(0.0002)$ & $(0.0010)$ & $(0.0002)$ \\
Observations & & & & & \\
R-squared & 703,417 & 57,711 & 645,706 & 57,711 & 645,706 \\
Number of group & 0.007 & 0.038 & 0.007 & 0.038 & 0.007 \\
\hline
\end{tabular}

Dependent variable is any investment in columns (1)-(5) and sample is the $\$ 50 \mathrm{~K}$ sample. Instead of cumulative investment, the regressions introduce a dummy for the presence of the entrepreneurs on the overall charts (Top 25). All regressions include a full set of fixed effects for each entrepreneur-investor pair (differenced out) and each week. Robust standard errors clustered at the pair level in parentheses. *** $\mathrm{p}<0.01,{ }^{* *} \mathrm{p}<0.05, * \mathrm{p}<0.1$ 
Table A-11: Controlling for songs and video uploads

\begin{tabular}{|c|c|c|c|c|c|}
\hline VARIABLES & $\begin{array}{c}(1) \\
\text { Invest }=1\end{array}$ & $\begin{array}{c}(2) \\
\text { LOCAL }\end{array}$ & $\begin{array}{c}(3) \\
\text { DISTANT }\end{array}$ & $\begin{array}{c}(4) \\
\text { LOCAL }\end{array}$ & $\begin{array}{c}(5) \\
\text { DISTANT }\end{array}$ \\
\hline$\$ 10-20 \mathrm{~K}$ accum. capital & $\begin{array}{c}0.0211^{* * *} \\
(0.0012)\end{array}$ & $\begin{array}{c}0.0051 \\
(0.0076)\end{array}$ & $\begin{array}{c}0.0212^{* * *} \\
(0.0013)\end{array}$ & $\begin{array}{c}0.0323^{* * *} \\
(0.0092)\end{array}$ & $\begin{array}{c}0.0229 * * * \\
(0.0012)\end{array}$ \\
\hline$\$ 20-30 \mathrm{~K}$ accum. capital & $\begin{array}{c}0.0277^{* * *} \\
(0.0017)\end{array}$ & $\begin{array}{c}-0.0257^{* *} \\
(0.0103)\end{array}$ & $\begin{array}{c}0.0299^{* * *} \\
(0.0017)\end{array}$ & $\begin{array}{c}0.0277^{* *} \\
(0.0121)\end{array}$ & $\begin{array}{c}0.0343^{* * *} \\
(0.0017)\end{array}$ \\
\hline$\$ 30-40 \mathrm{~K}$ accum. capital & $\begin{array}{c}0.0442^{* * *} \\
(0.0021)\end{array}$ & $\begin{array}{c}-0.0307^{* * *} \\
(0.0114)\end{array}$ & $\begin{array}{c}0.0473^{* * *} \\
(0.0021)\end{array}$ & $\begin{array}{c}0.0338^{* *} \\
(0.0144)\end{array}$ & $\begin{array}{c}0.0536^{* * *} \\
(0.0021)\end{array}$ \\
\hline$\$ 40-50 \mathrm{~K}$ accum. capital & $\begin{array}{c}0.0870^{* * *} \\
(0.0027)\end{array}$ & $\begin{array}{l}-0.0214 \\
(0.0133)\end{array}$ & $\begin{array}{c}0.0922^{* * *} \\
(0.0028)\end{array}$ & $\begin{array}{c}0.0536^{* * *} \\
(0.0173)\end{array}$ & $\begin{array}{c}0.1115^{* * *} \\
(0.0028)\end{array}$ \\
\hline$\$ 10-20 \mathrm{~K}$ accum. capital $*$ F\&F & & & & $\begin{array}{c}-0.0738^{* * *} \\
(0.0119)\end{array}$ & $\begin{array}{c}-0.0854^{* * *} \\
(0.0065)\end{array}$ \\
\hline$\$ 20-30 \mathrm{~K}$ accum. capital * F\&F & & & & $\begin{array}{c}-0.1121^{* * * *} \\
(0.0127)\end{array}$ & $\begin{array}{c}-0.1305^{* * *} \\
(0.0071)\end{array}$ \\
\hline$\$ 30-40 \mathrm{~K}$ accum. capital $*$ F\&F & & & & $\begin{array}{c}-0.1338^{* * * *} \\
(0.0153)\end{array}$ & $\begin{array}{c}-0.1564^{* * *} \\
(0.0073)\end{array}$ \\
\hline$\$ 40-50 \mathrm{~K}$ accum. capital $*$ F\&F & & & & $\begin{array}{c}-0.1531^{* * *} \\
(0.0178)\end{array}$ & $\begin{array}{c}-0.2444^{* * *} \\
(0.0079)\end{array}$ \\
\hline Weeks on Sellaband & $\begin{array}{c}-0.0018^{* * * *} \\
(0.0002)\end{array}$ & $\begin{array}{l}-0.0001 \\
(0.0010)\end{array}$ & $\begin{array}{c}-0.0018^{* * * *} \\
(0.0002)\end{array}$ & $\begin{array}{c}0.0002 \\
(0.0010)\end{array}$ & $\begin{array}{c}-0.0016^{* * *} \\
(0.0002)\end{array}$ \\
\hline Videos uploaded (lagged) & $\begin{array}{l}0.0084^{*} \\
(0.0043)\end{array}$ & $\begin{array}{c}0.2433^{* * *} \\
(0.0454)\end{array}$ & $\begin{array}{c}0.0011 \\
(0.0042)\end{array}$ & $\begin{array}{c}0.2441^{* * *} \\
(0.0440)\end{array}$ & $\begin{array}{c}0.0034 \\
(0.0041)\end{array}$ \\
\hline Songs uploaded (lagged) & $\begin{array}{l}-0.0012 \\
(0.0009)\end{array}$ & $\begin{array}{l}-0.0041 \\
(0.0029)\end{array}$ & $\begin{array}{l}-0.0010 \\
(0.0009)\end{array}$ & $\begin{array}{l}-0.0038 \\
(0.0028)\end{array}$ & $\begin{array}{l}-0.0018^{*} \\
(0.0009)\end{array}$ \\
\hline Observations & 703,417 & 57,711 & 645,706 & 57,711 & 645,706 \\
\hline R-squared & 0.011 & 0.042 & 0.012 & 0.050 & 0.018 \\
\hline Number of group & 18,827 & 1,164 & 17,663 & 1,164 & 17,663 \\
\hline
\end{tabular}

Dependent variable is any investment in columns (1)-(5), sample is the $\$ 50 \mathrm{~K}$ sample and controls for videos and songs uploaded by the entrepreneurs are included. All regressions include a full set of fixed effects for each entrepreneur-investor pair (differenced out) and each week. Robust standard errors clustered at the pair level in parentheses. ${ }^{* * *} \mathrm{p}<0.01,{ }^{* *}$ $\mathrm{p}<0.05,{ }^{*} \mathrm{p}<0.1$ 
Table A-12: Controlling for live shows

\begin{tabular}{|c|c|c|c|c|c|}
\hline VARIABLES & $\begin{array}{c}(1) \\
\text { Invest }=1\end{array}$ & $\begin{array}{c}(2) \\
\text { LOCAL }\end{array}$ & $\begin{array}{c}(3) \\
\text { DISTANT }\end{array}$ & $\begin{array}{c}(4) \\
\text { LOCAL }\end{array}$ & $\begin{array}{c}(5) \\
\text { DISTANT }\end{array}$ \\
\hline$\$ 10-20 \mathrm{~K}$ accum. capital & $\begin{array}{c}0.0213^{* * *} \\
(0.0012)\end{array}$ & $\begin{array}{c}0.0021 \\
(0.0076)\end{array}$ & $\begin{array}{c}0.0215^{* * *} \\
(0.0012)\end{array}$ & $\begin{array}{c}0.0322^{* * * *} \\
(0.0091)\end{array}$ & $\begin{array}{c}0.0233^{* * *} \\
(0.0012)\end{array}$ \\
\hline$\$ 20-30 \mathrm{~K}$ accum. capital & $\begin{array}{c}0.0261^{* * *} \\
(0.0017)\end{array}$ & $\begin{array}{c}-0.0288^{* * *} \\
(0.0103)\end{array}$ & $\begin{array}{c}0.0283^{* * *} \\
(0.0017)\end{array}$ & $\begin{array}{c}0.0276^{* *} \\
(0.0119)\end{array}$ & $\begin{array}{c}0.0329^{* * * *} \\
(0.0017)\end{array}$ \\
\hline$\$ 30-40 \mathrm{~K}$ accum. capital & $\begin{array}{c}0.0420^{* * *} \\
(0.0021)\end{array}$ & $\begin{array}{c}-0.0336^{* * *} \\
(0.0114)\end{array}$ & $\begin{array}{c}0.0451^{* * *} \\
(0.0021)\end{array}$ & $\begin{array}{c}0.0335^{* *} \\
(0.0143)\end{array}$ & $\begin{array}{c}0.0517^{* * *} \\
(0.0021)\end{array}$ \\
\hline \$40-50K accum. capital & $\begin{array}{c}0.0840^{* * *} \\
(0.0027)\end{array}$ & $\begin{array}{c}-0.0251^{*} \\
(0.0134)\end{array}$ & $\begin{array}{c}0.0891^{* * *} \\
(0.0028)\end{array}$ & $\begin{array}{c}0.0524^{* * *} \\
(0.0174)\end{array}$ & $\begin{array}{c}0.1086^{* * *} \\
(0.0028)\end{array}$ \\
\hline$\$ 10-20 \mathrm{~K}$ accum. capital $*$ F\&F & & & & $\begin{array}{c}-0.0803^{* * *} \\
(0.0121)\end{array}$ & $\begin{array}{c}-0.0909^{* * *} \\
(0.0065)\end{array}$ \\
\hline$\$ 20-30 \mathrm{~K}$ accum. capital $*$ F\&F & & & & $\begin{array}{c}-0.1184^{* * * *} \\
(0.0130)\end{array}$ & $\begin{array}{c}-0.1377^{* * *} \\
(0.0071)\end{array}$ \\
\hline$\$ 30-40 \mathrm{~K}$ accum. capital $*$ F\&F & & & & $\begin{array}{c}-0.1396^{* * * *} \\
(0.0155)\end{array}$ & $\begin{array}{c}-0.1644^{* * *} \\
(0.0073)\end{array}$ \\
\hline$\$ 40-50 \mathrm{~K}$ accum. capital $*$ F\&F & & & & $\begin{array}{c}-0.1590^{* * * *} \\
(0.0181)\end{array}$ & $\begin{array}{c}-0.2521^{* * *} \\
(0.0079)\end{array}$ \\
\hline Weeks on Sellaband & $\begin{array}{c}-0.0033^{* * *} \\
(0.0003)\end{array}$ & $\begin{array}{c}-0.0038^{* * *} \\
(0.0011)\end{array}$ & $\begin{array}{c}-0.0032^{* * *} \\
(0.0003)\end{array}$ & $\begin{array}{c}-0.0034^{* * *} \\
(0.0011)\end{array}$ & $\begin{array}{c}-0.0030^{* * *} \\
(0.0003)\end{array}$ \\
\hline Investor proximate to Live Show & $\begin{array}{c}0.0079 \\
(0.0056)\end{array}$ & $\begin{array}{c}0.0090 \\
(0.0087)\end{array}$ & $\begin{array}{l}-0.0053 \\
(0.0147)\end{array}$ & $\begin{array}{c}0.0085 \\
(0.0087)\end{array}$ & $\begin{array}{l}-0.0043 \\
(0.0146)\end{array}$ \\
\hline Observations & 709,471 & 57,855 & 651,616 & 57,855 & 651,616 \\
\hline R-squared & 0.012 & 0.042 & 0.012 & 0.050 & 0.019 \\
\hline Number of group & 18,827 & 1,164 & 17,663 & 1,164 & 17,663 \\
\hline
\end{tabular}

Dependent variable is any investment in columns (1)-(5), sample is the $\$ 50 \mathrm{~K}$ sample and a control for live shows proximate to the investor is included. All regressions include a full set of fixed effects for each entrepreneur-investor pair (differenced out) and each week. Robust standard errors clustered at the pair level in parentheses. ${ }^{* * *} \mathrm{p}<0.01,{ }^{* *} \mathrm{p}<0.05,{ }^{*} \mathrm{p}<0.1$ 
Table A-13: Controlling for live shows, songs, and video uploads

\begin{tabular}{|c|c|c|c|c|c|}
\hline VARIABLES & $\begin{array}{c}(1) \\
\text { Invest =1 }\end{array}$ & $\begin{array}{c}(2) \\
\text { LOCAL }\end{array}$ & $\begin{array}{c}(3) \\
\text { DISTANT }\end{array}$ & $\begin{array}{c}(4) \\
\text { LOCAL }\end{array}$ & $\begin{array}{c}(5) \\
\text { DISTANT }\end{array}$ \\
\hline \$10-20K accum. capital & $\begin{array}{c}0.0211^{* * *} \\
(0.0012)\end{array}$ & $\begin{array}{c}0.0051 \\
(0.0076)\end{array}$ & $\begin{array}{c}0.0212^{* * *} \\
(0.0013)\end{array}$ & $\begin{array}{c}0.0324^{* * * *} \\
(0.0092)\end{array}$ & $\begin{array}{c}0.0229^{* * *} \\
(0.0012)\end{array}$ \\
\hline$\$ 20-30 \mathrm{~K}$ accum. capital & $\begin{array}{c}0.0277^{* * *} \\
(0.0017)\end{array}$ & $\begin{array}{c}-0.0258^{* *} \\
(0.0103)\end{array}$ & $\begin{array}{c}0.0299^{* * *} \\
(0.0017)\end{array}$ & $\begin{array}{c}0.0277^{* *} \\
(0.0121)\end{array}$ & $\begin{array}{c}0.0343^{* * * *} \\
(0.0017)\end{array}$ \\
\hline \$30-40K accum. capital & $\begin{array}{c}0.0442^{* * *} \\
(0.0021)\end{array}$ & $\begin{array}{c}-0.0309 * * * \\
(0.0114)\end{array}$ & $\begin{array}{c}0.0473^{* * *} \\
(0.0021)\end{array}$ & $\begin{array}{l}0.0335^{* *} \\
(0.0144)\end{array}$ & $\begin{array}{c}0.0536^{* * *} \\
(0.0021)\end{array}$ \\
\hline$\$ 40-50 \mathrm{~K}$ accum. capital & $\begin{array}{c}0.0871^{* * *} \\
(0.0027)\end{array}$ & $\begin{array}{l}-0.0211 \\
(0.0133)\end{array}$ & $\begin{array}{c}0.0922^{* * *} \\
(0.0028)\end{array}$ & $\begin{array}{c}0.0539^{* * *} \\
(0.0173)\end{array}$ & $\begin{array}{c}0.1115^{* * *} \\
(0.0028)\end{array}$ \\
\hline$\$ 10-20 \mathrm{~K}$ accum. capital $*$ F\&F & & & & $\begin{array}{c}-0.0738^{* * *} \\
(0.0119)\end{array}$ & $\begin{array}{c}-0.0854^{* * *} \\
(0.0065)\end{array}$ \\
\hline$\$ 20-30 \mathrm{~K}$ accum. capital $*$ F\&F & & & & $\begin{array}{c}-0.1121^{* * *} \\
(0.0127)\end{array}$ & $\begin{array}{c}-0.1305^{* * *} \\
(0.0071)\end{array}$ \\
\hline$\$ 30-40 \mathrm{~K}$ accum. capital $*$ F\&F & & & & $\begin{array}{c}-0.1337^{* * * *} \\
(0.0153)\end{array}$ & $\begin{array}{c}-0.1565^{* * *} \\
(0.0073)\end{array}$ \\
\hline$\$ 40-50 \mathrm{~K}$ accum. capital $*$ F\&F & & & & $\begin{array}{c}-0.1531^{* * *} \\
(0.0178)\end{array}$ & $\begin{array}{c}-0.2444^{* * *} \\
(0.0079)\end{array}$ \\
\hline Weeks on Sellaband & $\begin{array}{c}-0.0018^{* * * *} \\
(0.0002)\end{array}$ & $\begin{array}{c}-0.0001 \\
(0.0010)\end{array}$ & $\begin{array}{c}-0.0018^{* * * *} \\
(0.0002)\end{array}$ & $\begin{array}{c}0.0002 \\
(0.0010)\end{array}$ & $\begin{array}{c}-0.0016^{* * *} \\
(0.0002)\end{array}$ \\
\hline Videos uploaded (lagged) & $\begin{array}{l}0.0084^{*} \\
(0.0043)\end{array}$ & $\begin{array}{c}0.2435^{* * *} \\
(0.0454)\end{array}$ & $\begin{array}{c}0.0011 \\
(0.0042)\end{array}$ & $\begin{array}{c}0.2444^{* * *} \\
(0.0440)\end{array}$ & $\begin{array}{c}0.0034 \\
(0.0041)\end{array}$ \\
\hline Songs uploaded (lagged) & $\begin{array}{l}-0.0011 \\
(0.0009)\end{array}$ & $\begin{array}{l}-0.0038 \\
(0.0029)\end{array}$ & $\begin{array}{l}-0.0010 \\
(0.0009)\end{array}$ & $\begin{array}{l}-0.0035 \\
(0.0029)\end{array}$ & $\begin{array}{c}-0.0018^{*} \\
(0.0009)\end{array}$ \\
\hline Investor proximate to Live Show & $\begin{array}{l}0.0098^{*} \\
(0.0056)\end{array}$ & $\begin{array}{c}0.0094 \\
(0.0086)\end{array}$ & $\begin{array}{c}0.0031 \\
(0.0148)\end{array}$ & $\begin{array}{l}0.0090 \\
(0.0087)\end{array}$ & $\begin{array}{c}0.0043 \\
(0.0147)\end{array}$ \\
\hline Observations & 703,417 & 57,711 & 645,706 & 57,711 & 645,706 \\
\hline R-squared & 0.011 & 0.042 & 0.012 & 0.050 & 0.018 \\
\hline Number of group & 18,827 & 1,164 & 17,663 & 1,164 & 17,663 \\
\hline
\end{tabular}

Dependent variable is any investment in columns (1)-(5), sample is the $\$ 50 \mathrm{~K}$ sample and controls for videos and songs uploaded by the entrepreneurs as well as live shows proximate to investor are included. All regressions include a full set of fixed effects for each entrepreneur-investor pair (differenced out) and each week. Robust standard errors clustered at the pair level in parentheses. ${ }^{* * *} \mathrm{p}<0.01,{ }^{* *} \mathrm{p}<0.05,{ }^{*} \mathrm{p}<0.1$ 
Table A-14: Focal investor's past investment not included in entrepreneur's accumulated capital.

\begin{tabular}{|c|c|c|c|c|c|}
\hline VARIABLES & $\begin{array}{c}(1) \\
\text { Invest }=1\end{array}$ & $\begin{array}{c}(2) \\
\text { LOCAL }\end{array}$ & $\begin{array}{c}(3) \\
\text { DISTANT }\end{array}$ & $\begin{array}{c}(4) \\
\text { LOCAL }\end{array}$ & $\begin{array}{c}(5) \\
\text { DISTANT }\end{array}$ \\
\hline$\$ 10-20 \mathrm{~K}$ accum. capital & $\begin{array}{c}0.0207^{* * *} \\
(0.0012)\end{array}$ & $\begin{array}{c}0.0030 \\
(0.0077)\end{array}$ & $\begin{array}{c}0.0210^{* * *} \\
(0.0012)\end{array}$ & $\begin{array}{c}0.0320^{* * *} \\
(0.0092)\end{array}$ & $\begin{array}{c}0.0226^{* * *} \\
(0.0012)\end{array}$ \\
\hline$\$ 20-30 \mathrm{~K}$ accum. capital & $\begin{array}{c}0.0253^{* * *} \\
(0.0017)\end{array}$ & $\begin{array}{c}-0.0282^{* * *} \\
(0.0103)\end{array}$ & $\begin{array}{c}0.0274^{* * *} \\
(0.0017)\end{array}$ & $\begin{array}{c}0.0287^{* *} \\
(0.0120)\end{array}$ & $\begin{array}{c}0.0321^{* * *} \\
(0.0017)\end{array}$ \\
\hline$\$ 30-40 \mathrm{~K}$ accum. capital & $\begin{array}{c}0.0413^{* * *} \\
(0.0021)\end{array}$ & $\begin{array}{c}-0.0332^{* * *} \\
(0.0114)\end{array}$ & $\begin{array}{c}0.0445^{* * *} \\
(0.0021)\end{array}$ & $\begin{array}{c}0.0325^{* *} \\
(0.0143)\end{array}$ & $\begin{array}{c}0.0511^{* * *} \\
(0.0021)\end{array}$ \\
\hline$\$ 40-50 \mathrm{~K}$ accum. capital & $\begin{array}{c}0.0830 * * * \\
(0.0027)\end{array}$ & $\begin{array}{c}-0.0259^{*} \\
(0.0135)\end{array}$ & $\begin{array}{c}0.0881^{* * *} \\
(0.0027)\end{array}$ & $\begin{array}{c}0.0531^{* * *} \\
(0.0171)\end{array}$ & $\begin{array}{c}0.1076^{* * *} \\
(0.0028)\end{array}$ \\
\hline$\$ 10-20 \mathrm{~K}$ accum. capital $*$ F\&F & & & & $\begin{array}{c}-0.0774^{* * *} \\
(0.0119)\end{array}$ & $\begin{array}{c}-0.0894 * * * \\
(0.0064)\end{array}$ \\
\hline$\$ 20-30 \mathrm{~K}$ accum. capital $*$ F\&F & & & & $\begin{array}{c}-0.1177^{* * *} \\
(0.0129)\end{array}$ & $\begin{array}{c}-0.1374^{* * *} \\
(0.0071)\end{array}$ \\
\hline$\$ 30-40 \mathrm{~K}$ accum. capital $*$ F\&F & & & & $\begin{array}{c}-0.1360 * * * \\
(0.0154)\end{array}$ & $\begin{array}{c}-0.1644^{* * *} \\
(0.0073)\end{array}$ \\
\hline$\$ 40-50 \mathrm{~K}$ accum. capital $* \mathrm{~F} \& \mathrm{~F}$ & & & & $\begin{array}{c}-0.1592^{* * *} \\
(0.0176)\end{array}$ & $\begin{array}{c}-0.2507^{* * *} \\
(0.0079)\end{array}$ \\
\hline Weeks on Sellaband & $\begin{array}{c}-0.0033^{* * *} \\
(0.0003)\end{array}$ & $\begin{array}{c}-0.0038^{* * *} \\
(0.0011)\end{array}$ & $\begin{array}{c}-0.0032^{* * *} \\
(0.0003)\end{array}$ & $\begin{array}{c}-0.0034^{* * *} \\
(0.0011)\end{array}$ & $\begin{array}{c}-0.0030 * * * \\
(0.0003)\end{array}$ \\
\hline Observations & 709,471 & 57,855 & 651,616 & 57,855 & 651,616 \\
\hline R-squared & 0.012 & 0.042 & 0.012 & 0.050 & 0.018 \\
\hline Number of group & 18,827 & 1,164 & 17,663 & 1,164 & 17,663 \\
\hline
\end{tabular}

Dependent variable is any investment in columns (1)-(5) and sample is the $\$ 50 \mathrm{~K}$ sample. All regressions include a full set of fixed effects for each entrepreneur-investor pair (differenced out) and each week. Robust standard errors clustered at the pair level in parentheses. *** $\mathrm{p}<0.01,{ }^{* *} \mathrm{p}<0.05,{ }^{*} \mathrm{p}<0.1$ 
Table A-15: Controlling for entrepreneurs' mentions in the Sellaband Newsletter.

\begin{tabular}{|c|c|c|c|c|c|}
\hline VARIABLES & $\begin{array}{c}(1) \\
\text { Invest }=1\end{array}$ & $\begin{array}{c}(2) \\
\text { LOCAL }\end{array}$ & $\begin{array}{c}(3) \\
\text { DISTANT }\end{array}$ & $\begin{array}{c}(4) \\
\text { LOCAL }\end{array}$ & $\begin{array}{c}(5) \\
\text { DISTANT }\end{array}$ \\
\hline$\$ 10-20 \mathrm{~K}$ accum. capital & $\begin{array}{c}0.0213^{* * *} \\
(0.0012)\end{array}$ & $\begin{array}{c}0.0022 \\
(0.0076)\end{array}$ & $\begin{array}{c}0.0216^{* * *} \\
(0.0012)\end{array}$ & $\begin{array}{c}0.0323^{* * *} \\
(0.0091)\end{array}$ & $\begin{array}{c}0.0233^{* * *} \\
(0.0012)\end{array}$ \\
\hline$\$ 20-30 \mathrm{~K}$ accum. capital & $\begin{array}{c}0.0261^{* * *} \\
(0.0017)\end{array}$ & $\begin{array}{c}-0.0287^{* * *} \\
(0.0103)\end{array}$ & $\begin{array}{c}0.0283^{* * *} \\
(0.0017)\end{array}$ & $\begin{array}{c}0.0275^{* *} \\
(0.0119)\end{array}$ & $\begin{array}{c}0.0329 * * * \\
(0.0017)\end{array}$ \\
\hline$\$ 30-40 \mathrm{~K}$ accum. capital & $\begin{array}{c}0.0419 * * * \\
(0.0021)\end{array}$ & $\begin{array}{c}-0.0335^{* * *} \\
(0.0114)\end{array}$ & $\begin{array}{c}0.0451^{* * *} \\
(0.0021)\end{array}$ & $\begin{array}{c}0.0336^{* *} \\
(0.0143)\end{array}$ & $\begin{array}{c}0.0517^{* * *} \\
(0.0021)\end{array}$ \\
\hline$\$ 40-50 \mathrm{~K}$ accum. capital & $\begin{array}{c}0.0840 * * * \\
(0.0027)\end{array}$ & $\begin{array}{l}-0.0252^{*} \\
(0.0134)\end{array}$ & $\begin{array}{c}0.0890 * * * \\
(0.0028)\end{array}$ & $\begin{array}{c}0.0522^{* * *} \\
(0.0174)\end{array}$ & $\begin{array}{c}0.1086^{* * *} \\
(0.0028)\end{array}$ \\
\hline$\$ 10-20 \mathrm{~K}$ accum. capital $* \mathrm{~F} \& \mathrm{~F}$ & & & & $\begin{array}{c}-0.0803^{* * *} \\
(0.0121)\end{array}$ & $\begin{array}{c}-0.0909 * * * \\
(0.0065)\end{array}$ \\
\hline$\$ 20-30 \mathrm{~K}$ accum. capital $* \mathrm{~F} \& \mathrm{~F}$ & & & & $\begin{array}{c}-0.1182^{* * *} \\
(0.0129)\end{array}$ & $\begin{array}{c}-0.1377^{* * *} \\
(0.0071)\end{array}$ \\
\hline$\$ 30-40 \mathrm{~K}$ accum. capital $* \mathrm{~F} \& \mathrm{~F}$ & & & & $\begin{array}{c}-0.1395^{* * *} \\
(0.0154)\end{array}$ & $\begin{array}{c}-0.1644^{* * *} \\
(0.0073)\end{array}$ \\
\hline$\$ 40-50 \mathrm{~K}$ accum. capital $* \mathrm{~F} \& \mathrm{~F}$ & & & & $\begin{array}{c}-0.1588^{* * *} \\
(0.0181)\end{array}$ & $\begin{array}{c}-0.2520^{* * *} \\
(0.0079)\end{array}$ \\
\hline Weeks on Sellaband & $\begin{array}{c}-0.0033^{* * *} \\
(0.0003)\end{array}$ & $\begin{array}{c}-0.0038^{* * *} \\
(0.0011)\end{array}$ & $\begin{array}{c}-0.0032^{* * *} \\
(0.0003)\end{array}$ & $\begin{array}{c}-0.0034^{* * *} \\
(0.0011)\end{array}$ & $\begin{array}{c}-0.0030 * * * \\
(0.0003)\end{array}$ \\
\hline Artist in Newsletter (lagged) & $\begin{array}{c}0.0035^{* *} \\
(0.0016)\end{array}$ & $\begin{array}{c}0.0104 \\
(0.0083)\end{array}$ & $\begin{array}{c}0.0026 \\
(0.0017)\end{array}$ & $\begin{array}{c}0.0075 \\
(0.0081)\end{array}$ & $\begin{array}{c}0.0015 \\
(0.0017)\end{array}$ \\
\hline Observations & 709,471 & 57,855 & 651,616 & 57,855 & 651,616 \\
\hline R-squared & 0.012 & 0.042 & 0.012 & 0.050 & 0.019 \\
\hline Number of group & 18,827 & 1,164 & 17,663 & 1,164 & 17,663 \\
\hline
\end{tabular}

Dependent variable is any investment in columns (1)-(5) and sample is the $\$ 50 \mathrm{~K}$ sample and a control for the entrepreneur's being mentioned in the Sellaband Newsletter is included. All regressions include a full set of fixed effects for each entrepreneur-investor pair (differenced out) and each week. Robust standard errors clustered at the pair level in parentheses. *** $\mathrm{p}<0.01, * * \mathrm{p}<0.05, * \mathrm{p}<0.1$ 
Table A-16: Logit

\begin{tabular}{|c|c|c|c|c|c|}
\hline VARIABLES & $\begin{array}{c}(1) \\
\text { Invest }=1\end{array}$ & $\begin{array}{c}(2) \\
\mathrm{LOCAL}\end{array}$ & $\begin{array}{c}(3) \\
\text { DISTANT }\end{array}$ & $\begin{array}{c}(4) \\
\text { LOCAL }\end{array}$ & $\begin{array}{c}(5) \\
\text { DISTANT }\end{array}$ \\
\hline$\$ 10-20 \mathrm{~K}$ accum. capital & $\begin{array}{c}0.6432^{* * *} \\
(0.0256)\end{array}$ & $\begin{array}{c}0.3079^{* * *} \\
(0.0957)\end{array}$ & $\begin{array}{c}0.6240^{* * *} \\
(0.0269)\end{array}$ & $\begin{array}{c}0.8609^{* * *} \\
(0.1260)\end{array}$ & $\begin{array}{c}0.7329^{* * *} \\
(0.0285)\end{array}$ \\
\hline$\$ 20-30 \mathrm{~K}$ accum. capital & $\begin{array}{c}0.7433^{* * *} \\
(0.0322)\end{array}$ & $\begin{array}{c}-0.3996^{* * *} \\
(0.1320)\end{array}$ & $\begin{array}{c}0.7682^{* * *} \\
(0.0334)\end{array}$ & $\begin{array}{c}1.0674^{* * *} \\
(0.1602)\end{array}$ & $\begin{array}{c}1.0027^{* * *} \\
(0.0349)\end{array}$ \\
\hline$\$ 30-40 \mathrm{~K}$ accum. capital & $\begin{array}{c}1.1940^{* * *} \\
(0.0374)\end{array}$ & $\begin{array}{c}-0.2021 \\
(0.1556)\end{array}$ & $\begin{array}{c}1.2103^{* * *} \\
(0.0389)\end{array}$ & $\begin{array}{c}1.5558^{* * *} \\
(0.1897)\end{array}$ & $\begin{array}{c}1.5084^{* * *} \\
(0.0405)\end{array}$ \\
\hline$\$ 40-50 \mathrm{~K}$ accum. capital & $\begin{array}{c}1.7968^{* * *} \\
(0.0390)\end{array}$ & $\begin{array}{c}0.0809 \\
(0.1729)\end{array}$ & $\begin{array}{c}1.8185^{* * *} \\
(0.0405)\end{array}$ & $\begin{array}{c}1.8057^{* * *} \\
(0.2084)\end{array}$ & $\begin{array}{c}2.2355^{* * *} \\
(0.0420)\end{array}$ \\
\hline$\$ 10-20 \mathrm{~K}$ accum. capital $* \mathrm{~F} \& \mathrm{~F}$ & & & & $\begin{array}{c}-1.3487^{* * *} \\
(0.1511)\end{array}$ & $\begin{array}{c}-2.0564^{* * *} \\
(0.0782)\end{array}$ \\
\hline$\$ 20-30 \mathrm{~K}$ accum. capital $* \mathrm{~F} \& \mathrm{~F}$ & & & & $\begin{array}{c}-3.0243^{* * *} \\
(0.1786)\end{array}$ & $\begin{array}{c}-3.7040^{* * *} \\
(0.0947)\end{array}$ \\
\hline$\$ 30-40 \mathrm{~K}$ accum. capital $*$ F\&F & & & & $\begin{array}{c}-3.9613^{* * *} \\
(0.2345)\end{array}$ & $\begin{array}{c}-4.9193^{* * *} \\
(0.1144)\end{array}$ \\
\hline$\$ 40-50 \mathrm{~K}$ accum. capital $* \mathrm{~F} \& \mathrm{~F}$ & & & & $\begin{array}{c}-4.0348^{* * *} \\
(0.2678)\end{array}$ & $\begin{array}{c}-6.3398^{* * *} \\
(0.1291)\end{array}$ \\
\hline 4 th to 6 th month on Sellaband & $\begin{array}{c}-0.3783^{* * *} \\
(0.0279)\end{array}$ & $\begin{array}{c}-1.3247^{* * *} \\
(0.1049)\end{array}$ & $\begin{array}{c}-0.2978^{* * *} \\
(0.0294)\end{array}$ & $\begin{array}{c}-1.0737^{* * *} \\
(0.1068)\end{array}$ & $\begin{array}{c}-0.2839^{* * *} \\
(0.0300)\end{array}$ \\
\hline 6th to 12 th month on Sellaband & $\begin{array}{c}-0.4824^{* * *} \\
(0.0372)\end{array}$ & $\begin{array}{c}-1.3960^{* * *} \\
(0.1533)\end{array}$ & $\begin{array}{c}-0.4169^{* * *} \\
(0.0390)\end{array}$ & $\begin{array}{c}-1.0986^{* * *} \\
(0.1599)\end{array}$ & $\begin{array}{c}-0.4301^{* * *} \\
(0.0399)\end{array}$ \\
\hline $12+$ months on Sellaband & $\begin{array}{c}-0.1901^{* * *} \\
(0.0588)\end{array}$ & $\begin{array}{c}-1.1235^{* * *} \\
(0.2402)\end{array}$ & $\begin{array}{c}-0.1468^{* *} \\
(0.0614)\end{array}$ & $\begin{array}{c}-0.6649 * * * \\
(0.2507)\end{array}$ & $\begin{array}{c}-0.2054^{* * *} \\
(0.0623)\end{array}$ \\
\hline Observations & 708,745 & 57,814 & 650,931 & 57,814 & 650,931 \\
\hline Number of group & 18,234 & 1,127 & 17,107 & 1,127 & 17,107 \\
\hline Log Likelihood & -85893 & -5618 & -79645 & -5358 & -77706 \\
\hline
\end{tabular}

Dependent variable is any investment in columns (1)-(5) and sample is the $\$ 50 \mathrm{~K}$ sample. All Logit regressions include a full set of fixed effects for each entrepreneur-investor pair (differenced out using xtlogit command in Stata) and each week. Using dummies instead of the Weeks on Sellaband variable because of sample size. Robust standard errors clustered at the pair level in parentheses. $* * * \mathrm{p}<0.01, * * \mathrm{p}<0.05,{ }^{*} \mathrm{p}<0.1$ 
Table A-17: Positive Parts, fixed effects Poisson

\begin{tabular}{|c|c|c|c|c|c|}
\hline VARIABLES & $\begin{array}{c}(1) \\
\text { Invest }=1\end{array}$ & $\begin{array}{c}(2) \\
\mathrm{LOCAL}\end{array}$ & $\begin{array}{c}(3) \\
\text { DISTANT }\end{array}$ & $\begin{array}{c}(4) \\
\mathrm{LOCAL}\end{array}$ & $\begin{array}{c}(5) \\
\text { DISTANT }\end{array}$ \\
\hline$\$ 10-20 \mathrm{~K}$ accum. capital & $\begin{array}{c}0.6125^{* * *} \\
(0.0719)\end{array}$ & $\begin{array}{c}0.2056 \\
(0.2130)\end{array}$ & $\begin{array}{c}0.6557^{* * *} \\
(0.0724)\end{array}$ & $\begin{array}{c}0.8511^{* *} \\
(0.3688)\end{array}$ & $\begin{array}{c}0.7768^{* * *} \\
(0.0769)\end{array}$ \\
\hline$\$ 20-30 \mathrm{~K}$ accum. capital & $\begin{array}{c}0.7437^{* * *} \\
(0.0972)\end{array}$ & $\begin{array}{c}0.1918 \\
(0.2654)\end{array}$ & $\begin{array}{c}0.8329^{* * *} \\
(0.1020)\end{array}$ & $\begin{array}{c}1.1017^{* * *} \\
(0.3380)\end{array}$ & $\begin{array}{c}1.0107^{* * *} \\
(0.1053)\end{array}$ \\
\hline$\$ 30-40 \mathrm{~K}$ accum. capital & $\begin{array}{c}1.1358^{* * *} \\
(0.1108)\end{array}$ & $\begin{array}{c}0.2115 \\
(0.2693)\end{array}$ & $\begin{array}{c}1.2882^{* * *} \\
(0.1103)\end{array}$ & $\begin{array}{c}1.3225^{* * *} \\
(0.3801)\end{array}$ & $\begin{array}{c}1.5411^{* * *} \\
(0.1133)\end{array}$ \\
\hline$\$ 40-50 \mathrm{~K}$ accum. capital & $\begin{array}{c}1.9297^{* * *} \\
(0.1096)\end{array}$ & $\begin{array}{c}0.8957^{* * *} \\
(0.3299)\end{array}$ & $\begin{array}{c}2.1000^{* * *} \\
(0.1161)\end{array}$ & $\begin{array}{c}1.9935^{* * *} \\
(0.4508)\end{array}$ & $\begin{array}{c}2.4439^{* * *} \\
(0.1168)\end{array}$ \\
\hline$\$ 10-20 \mathrm{~K}$ accum. capital $* \mathrm{~F} \& \mathrm{~F}$ & & & & $\begin{array}{c}-1.4389^{* * *} \\
(0.4415)\end{array}$ & $\begin{array}{c}-1.4033^{\text {*** }} \\
(0.1593)\end{array}$ \\
\hline$\$ 20-30 \mathrm{~K}$ accum. capital $* \mathrm{~F} \& \mathrm{~F}$ & & & & $\begin{array}{c}-2.1077^{* * *} \\
(0.5066)\end{array}$ & $\begin{array}{c}-2.2160^{* * *} \\
(0.2359)\end{array}$ \\
\hline$\$ 30-40 \mathrm{~K}$ accum. capital $*$ F\&F & & & & $\begin{array}{c}-2.9714^{* * *} \\
(0.5841)\end{array}$ & $\begin{array}{c}-3.1398^{* * *} \\
(0.2974)\end{array}$ \\
\hline$\$ 40-50 \mathrm{~K}$ accum. capital $* \mathrm{~F} \& \mathrm{~F}$ & & & & $\begin{array}{c}-3.0136^{* * *} \\
(0.6693)\end{array}$ & $\begin{array}{c}-4.4171^{* * *} \\
(0.3431)\end{array}$ \\
\hline 4 th to 6 th month on Sellaband & $\begin{array}{c}-0.2544^{* * *} \\
(0.0759)\end{array}$ & $\begin{array}{l}-0.2450 \\
(0.2459)\end{array}$ & $\begin{array}{c}-0.2350^{* * *} \\
(0.0802)\end{array}$ & $\begin{array}{l}-0.1097 \\
(0.2341)\end{array}$ & $\begin{array}{c}-0.2442^{* * * *} \\
(0.0808)\end{array}$ \\
\hline 6th to 12 th month on Sellaband & $\begin{array}{c}-0.3933^{* * *} \\
(0.1116)\end{array}$ & $\begin{array}{c}0.4146 \\
(0.3058)\end{array}$ & $\begin{array}{c}-0.5319^{* * *} \\
(0.1157)\end{array}$ & $\begin{array}{c}0.4868^{*} \\
(0.2912)\end{array}$ & $\begin{array}{c}-0.5739^{* * *} \\
(0.1177)\end{array}$ \\
\hline $12+$ months on Sellaband & $\begin{array}{l}-0.0492 \\
(0.1602)\end{array}$ & $\begin{array}{c}0.7642^{* *} \\
(0.3791)\end{array}$ & $\begin{array}{l}-0.2378 \\
(0.1665)\end{array}$ & $\begin{array}{c}1.0372^{* *} \\
(0.4201)\end{array}$ & $\begin{array}{c}-0.3323^{* *} \\
(0.1686)\end{array}$ \\
\hline Observations & 708,966 & 57,820 & 651,146 & 57,820 & 651,146 \\
\hline Number of group & 18,322 & 1,129 & 17,193 & 1,129 & 17,193 \\
\hline Log Likelihood & -343532 & -36367 & -300653 & -34846 & -293783 \\
\hline
\end{tabular}

Dependent variable is positive parts in columns (1)-(5) and sample is the $\$ 50 \mathrm{~K}$ sample. All Poisson regressions include a full set of fixed effects for each entrepreneur-investor pair (differenced out) and each week. Estimated using xtpqml in stata (Simcoe 2007). Using dummies instead of the Weeks on Sellaband variable because of sample size. Robust standard errors clustered at the pair level in parentheses. ${ }^{* * *} \mathrm{p}<0.01,{ }^{* *} \mathrm{p}<0.05,{ }^{*} \mathrm{p}<0.1$ 
Table A-18: Total Parts, OLS

\begin{tabular}{lccccc}
\hline & $(1)$ & $(2)$ & $(3)$ & $(4)$ & $(5)$ \\
VARIABLES & Invest $=1$ & LOCAL & DISTANT & LOCAL & DISTANT \\
\hline \$10-20K accum. capital & $0.1216^{* * *}$ & 0.2116 & $0.1173^{* * *}$ & $0.5943^{* * *}$ & $0.1268^{* * *}$ \\
& $(0.0176)$ & $(0.1710)$ & $(0.0170)$ & $(0.2115)$ & $(0.0172)$ \\
\$20-30K accum. capital & $0.1654^{* * *}$ & 0.1290 & $0.1640^{* * *}$ & $0.7685^{* *}$ & $0.1787^{* * *}$ \\
& $(0.0280)$ & $(0.2492)$ & $(0.0272)$ & $(0.3080)$ & $(0.0273)$ \\
\$30-40K accum. capital & $0.2575^{* * *}$ & 0.1218 & $0.2621^{* * *}$ & $0.7840^{* * *}$ & $0.2878^{* * *}$ \\
& $(0.0353)$ & $(0.2733)$ & $(0.0344)$ & $(0.3000)$ & $(0.0349)$ \\
\$40-50K accum. capital & $0.6279^{* * *}$ & 0.2909 & $0.6516^{* * *}$ & 1.4283 & $0.7572^{* * *}$ \\
& $(0.0560)$ & $(0.5770)$ & $(0.0534)$ & $(0.9797)$ & $(0.0568)$ \\
\$10-20K accum. capital * F\&F & & & & $-0.9861^{* * *}$ & $-0.4108^{* * *}$ \\
& & & & $-1.3505^{* * *}$ & $-0.5489^{* * *}$ \\
\$20-30K accum. capital * F\&F & & & & $(0.2943)$ & $(0.0618)$ \\
& & & & $-1.4375^{* * *}$ & $-0.6860^{* * *}$ \\
\$30-40K accum. capital * F\&F & & & & $(0.2934)$ & $(0.0710)$ \\
& & & & $-2.1922^{* * *}$ & $-1.2360^{* * *}$ \\
\$40-50K accum. capital * F\&F & & & & $(0.7818)$ & $(0.0811)$ \\
& & & & \\
Weeks on Sellaband & $-0.0095^{* * *}$ & $-0.0162^{* *}$ & $-0.0092^{* *}$ & -0.0112 & $-0.0086^{* *}$ \\
& $(0.0035)$ & $(0.0078)$ & $(0.0037)$ & $(0.0071)$ & $(0.0037)$ \\
Observations & & & & & \\
R-squared & 709,471 & 57,855 & 651,616 & 57,855 & 651,616 \\
Number of group & 0.002 & 0.004 & 0.003 & 0.005 & 0.004 \\
\hline
\end{tabular}

Dependent variable is total parts in columns (1)-(5) and sample is the $\$ 50 \mathrm{~K}$ sample. Total parts includes a small number of disinvestments where investors withdraw money from an entrepreneur. Therefore, the analysis is done with OLS rather than fixed effects poisson. All regressions include a full set of fixed effects for each entrepreneur-investor pair (differenced out) and each week. Robust standard errors clustered at the pair level in parentheses. $* * *$ $\mathrm{p}<0.01,{ }^{* *} \mathrm{p}<0.05,{ }^{*} \mathrm{p}<0.1$ 
Table A-19: Random Effects.

\begin{tabular}{|c|c|c|c|c|c|}
\hline VARIABLES & $\begin{array}{c}(1) \\
\text { Invest }=1\end{array}$ & $\begin{array}{c}(2) \\
\text { LOCAL }\end{array}$ & $\begin{array}{c}(3) \\
\text { DISTANT }\end{array}$ & $\begin{array}{c}(4) \\
\text { LOCAL }\end{array}$ & $\begin{array}{c}(5) \\
\text { DISTANT }\end{array}$ \\
\hline$\$ 10-20 \mathrm{~K}$ accum. capital & $\begin{array}{c}0.0297^{* * *} \\
(0.0011)\end{array}$ & $\begin{array}{c}0.0000 \\
(0.0067)\end{array}$ & $\begin{array}{c}0.0307^{* * *} \\
(0.0011)\end{array}$ & $\begin{array}{c}0.0229 * * * \\
(0.0080)\end{array}$ & $\begin{array}{c}0.0291^{* * *} \\
(0.0011)\end{array}$ \\
\hline$\$ 20-30 \mathrm{~K}$ accum. capital & $\begin{array}{c}0.0420^{* * *} \\
(0.0013)\end{array}$ & $\begin{array}{c}-0.0179^{* *} \\
(0.0086)\end{array}$ & $\begin{array}{c}0.0446^{* * *} \\
(0.0014)\end{array}$ & $\begin{array}{c}0.0281^{* * *} \\
(0.0101)\end{array}$ & $\begin{array}{c}0.0460 * * * \\
(0.0014)\end{array}$ \\
\hline$\$ 30-40 \mathrm{~K}$ accum. capital & $\begin{array}{c}0.0677^{* * *} \\
(0.0017)\end{array}$ & $\begin{array}{l}-0.0105 \\
(0.0095)\end{array}$ & $\begin{array}{c}0.0712^{* * *} \\
(0.0017)\end{array}$ & $\begin{array}{c}0.0443^{* * *} \\
(0.0126)\end{array}$ & $\begin{array}{c}0.0737^{* * *} \\
(0.0017)\end{array}$ \\
\hline$\$ 40-50 \mathrm{~K}$ accum. capital & $\begin{array}{c}0.1251^{* * *} \\
(0.0023)\end{array}$ & $\begin{array}{l}0.0200^{*} \\
(0.0115)\end{array}$ & $\begin{array}{c}0.1306^{* * *} \\
(0.0023)\end{array}$ & $\begin{array}{c}0.0787^{* * *} \\
(0.0159)\end{array}$ & $\begin{array}{c}0.1409^{* * *} \\
(0.0024)\end{array}$ \\
\hline$\$ 10-20 \mathrm{~K}$ accum. capital $*$ F\&F & & & & $\begin{array}{c}-0.0547^{* * *} \\
(0.0086)\end{array}$ & $\begin{array}{c}0.0153^{* * *} \\
(0.0031)\end{array}$ \\
\hline$\$ 20-30 \mathrm{~K}$ accum. capital $*$ F\&F & & & & $\begin{array}{c}-0.0857^{* * *} \\
(0.0090)\end{array}$ & $\begin{array}{c}-0.0133^{* * *} \\
(0.0025)\end{array}$ \\
\hline$\$ 30-40 \mathrm{~K}$ accum. c & & & & $\begin{array}{c}-0.1030^{* * *} \\
(0.0117)\end{array}$ & $\begin{array}{c}-0.0212^{* * *} \\
(0.0028)\end{array}$ \\
\hline$\$ 40-50 \mathrm{~K}$ accum. capital $*$ F\&F & & & & $\begin{array}{c}-0.1100^{* * *} \\
(0.0150)\end{array}$ & $\begin{array}{c}-0.0686^{* * * *} \\
(0.0041)\end{array}$ \\
\hline Weeks on Sellaband & $\begin{array}{c}-0.00106^{* * *} \\
(0.00003)\end{array}$ & $\begin{array}{c}-0.0015^{* * *} \\
(0.0003)\end{array}$ & $\begin{array}{c}-0.00105^{* * *} \\
(0.00003)\end{array}$ & $\begin{array}{c}-0.0018^{* * *} \\
(0.0003)\end{array}$ & $\begin{array}{c}-0.00105^{* * *} \\
(0.00003)\end{array}$ \\
\hline Obs & 709,471 & 57,855 & 651 , & 57,855 & 651,616 \\
\hline Number of group & 18,827 & 1,164 & 17,663 & 1,164 & 17,663 \\
\hline
\end{tabular}

Dependent variable is any investment in columns (1)-(5) and sample is the $\$ 50 \mathrm{~K}$ sample. All regressions include a full set of random effects for each entrepreneur-investor pair and fixed effects for each week. Robust standard errors clustered at the pair level in parentheses. ${ }^{* * *} \mathrm{p}<0.01,{ }^{* *}$ $\mathrm{p}<0.05,{ }^{*} \mathrm{p}<0.1$ 
Table A-20: Local defined as within $25 \mathrm{~km}$

\begin{tabular}{|c|c|c|c|c|}
\hline VARIABLES & $\begin{array}{c}(1) \\
\text { LOCAL } 25 \mathrm{~km}\end{array}$ & $\begin{array}{c}(2) \\
\text { DISTANT }\end{array}$ & $\begin{array}{c}(3) \\
\text { LOCAL } 25 \mathrm{~km}\end{array}$ & $\begin{array}{c}(4) \\
\text { DISTANT }\end{array}$ \\
\hline$\$ 10-20 \mathrm{~K}$ accum. capital & $\begin{array}{l}-0.0102 \\
(0.0089)\end{array}$ & $\begin{array}{c}0.0218^{* * *} \\
(0.0012)\end{array}$ & $\begin{array}{l}0.0194^{*} \\
(0.0108)\end{array}$ & $\begin{array}{c}0.0232^{* * * *} \\
(0.0012)\end{array}$ \\
\hline$\$ 20-30 \mathrm{~K}$ accum. capital & $\begin{array}{c}-0.0455^{* * *} \\
(0.0121)\end{array}$ & $\begin{array}{c}0.0283^{* * *} \\
(0.0017)\end{array}$ & $\begin{array}{c}0.0057 \\
(0.0142)\end{array}$ & $\begin{array}{c}0.0327^{* * *} \\
(0.0017)\end{array}$ \\
\hline$\$ 30-40 \mathrm{~K}$ accum. capital & $\begin{array}{c}-0.0430^{* * *} \\
(0.0134)\end{array}$ & $\begin{array}{c}0.0444^{* * *} \\
(0.0021)\end{array}$ & $\begin{array}{c}0.0178 \\
(0.0167)\end{array}$ & $\begin{array}{c}0.0503^{* * *} \\
(0.0021)\end{array}$ \\
\hline$\$ 40-50 \mathrm{~K}$ accum. capital & $\begin{array}{c}-0.0283^{*} \\
(0.0156)\end{array}$ & $\begin{array}{c}0.0873^{* * *} \\
(0.0027)\end{array}$ & $\begin{array}{c}0.0448^{* *} \\
(0.0206)\end{array}$ & $\begin{array}{c}0.1068^{* * *} \\
(0.0028)\end{array}$ \\
\hline$\$ 10-20 \mathrm{~K}$ accum. capital $*$ F\&F & & & $\begin{array}{c}-0.0759^{* * *} \\
(0.0139)\end{array}$ & $\begin{array}{c}-0.0943 * * * \\
(0.0062)\end{array}$ \\
\hline$\$ 20-30 \mathrm{~K}$ accum. capital $*$ F\&F & & & $\begin{array}{c}-0.1098^{* * * *} \\
(0.0148)\end{array}$ & $\begin{array}{c}-0.1356^{* * *} \\
(0.0066)\end{array}$ \\
\hline$\$ 30-40 \mathrm{~K}$ accum. capital $*$ F\&F & & & $\begin{array}{c}-0.1288^{* * *} \\
(0.0173)\end{array}$ & $\begin{array}{c}-0.1638^{* * * *} \\
(0.0069)\end{array}$ \\
\hline$\$ 40-50 \mathrm{~K}$ accum. capital $* \mathrm{~F} \& \mathrm{~F}$ & & & $\begin{array}{c}-0.1514^{* * *} \\
(0.0216)\end{array}$ & $\begin{array}{c}-0.2463^{* * *} \\
(0.0074)\end{array}$ \\
\hline Weeks on Sellaband & $\begin{array}{c}-0.0033^{* * *} \\
(0.0012)\end{array}$ & $\begin{array}{c}-0.0032^{* * *} \\
(0.0003)\end{array}$ & $\begin{array}{c}-0.0029^{* *} \\
(0.0012)\end{array}$ & $\begin{array}{c}-0.0031^{* * * *} \\
(0.0003)\end{array}$ \\
\hline Observations & 36,186 & 673,285 & 36,186 & 673,285 \\
\hline R-squared & 0.035 & 0.012 & 0.043 & 0.019 \\
\hline Number of group & 748 & 18,079 & 748 & 18,079 \\
\hline
\end{tabular}

Dependent variable is any investment in columns (1)-(4) and sample is the $\$ 50 \mathrm{~K}$ sample. All investors within $25 \mathrm{~km}$ from the entrepreneurs are here coded as local investors. All regressions include a full set of fixed effects for each entrepreneur-investor pair (differenced out) and each week. Robust standard errors clustered at the pair level in parentheses. $* * *$ $\mathrm{p}<0.01,{ }^{* *} \mathrm{p}<0.05,{ }^{*} \mathrm{p}<0.1$ 
Table A-21: Local defined as within $100 \mathrm{~km}$

\begin{tabular}{lcccc}
\hline & $(1)$ & $(2)$ & $(3)$ & $(4)$ \\
VARIABLES & LOCAL 100 km & DISTANT & LOCAL 100 km & DISTANT \\
\hline \$10-20K accum. capital & 0.0082 & $0.0216^{* * *}$ & $0.0340^{* * *}$ & $0.0236^{* * *}$ \\
& $(0.0061)$ & $(0.0013)$ & $(0.0068)$ & $(0.0012)$ \\
\$20-30K accum. capital & $-0.0225^{* * *}$ & $0.0290^{* * *}$ & $0.0307^{* * *}$ & $0.0336^{* * *}$ \\
& $(0.0082)$ & $(0.0017)$ & $(0.0092)$ & $(0.0017)$ \\
\$30-40K accum. capital & $-0.0254^{* * *}$ & $0.0458^{* * *}$ & $0.0379^{* * *}$ & $0.0527^{* * *}$ \\
& $(0.0093)$ & $(0.0022)$ & $(0.0110)$ & $(0.0021)$ \\
\$40-50K accum. capital & -0.0140 & $0.0902^{* * *}$ & $0.0637^{* * *}$ & $0.1099^{* * *}$ \\
& $(0.0110)$ & $(0.0028)$ & $(0.0137)$ & $(0.0029)$ \\
\$10-20K accum. capital * F\&F & & & $-0.0898^{* * *}$ & $-0.0876^{* * *}$ \\
& & & $(0.0102)$ & $(0.0066)$ \\
\$20-30K accum. capital * F\&F & & & $-0.1301^{* * *}$ & $-0.1346^{* * *}$ \\
& & & $-0.0111)$ & $(0.0073)$ \\
\$30-40K accum. capital * F\&F & & & $(0.0127)$ & $-0.1657^{* * *}$ \\
& & & $-0.1813^{* * *}$ & $-0.2533^{* * *}$ \\
\$40-50K accum. capital * F\&F & & & $(0.0154)$ & $(0.0082)$ \\
& & & & \\
& & & & \\
Weeks on Sellaband & $-0.0041^{* * *}$ & $-0.0031^{* * *}$ & $-0.0035^{* * *}$ & $-0.0030^{* * *}$ \\
& $(0.0011)$ & $(0.0003)$ & $(0.0010)$ & $(0.0003)$ \\
Observations & & & & \\
R-squared & 78,897 & 630,574 & 78,897 & 630,574 \\
Number of group & 0.039 & 0.012 & 0.049 & 0.018 \\
\hline
\end{tabular}

Dependent variable is any investment in columns (1)-(4) and sample is the $\$ 50 \mathrm{~K}$ sample. All investors within $100 \mathrm{~km}$ from the entrepreneurs are here coded as local investors. All regressions include a full set of fixed effects for each entrepreneur-investor pair (differenced out) and each week. Robust standard errors clustered at the pair level in parentheses. *** $\mathrm{p}<0.01,{ }^{* *} \mathrm{p}<0.05,{ }^{*} \mathrm{p}<0.1$ 


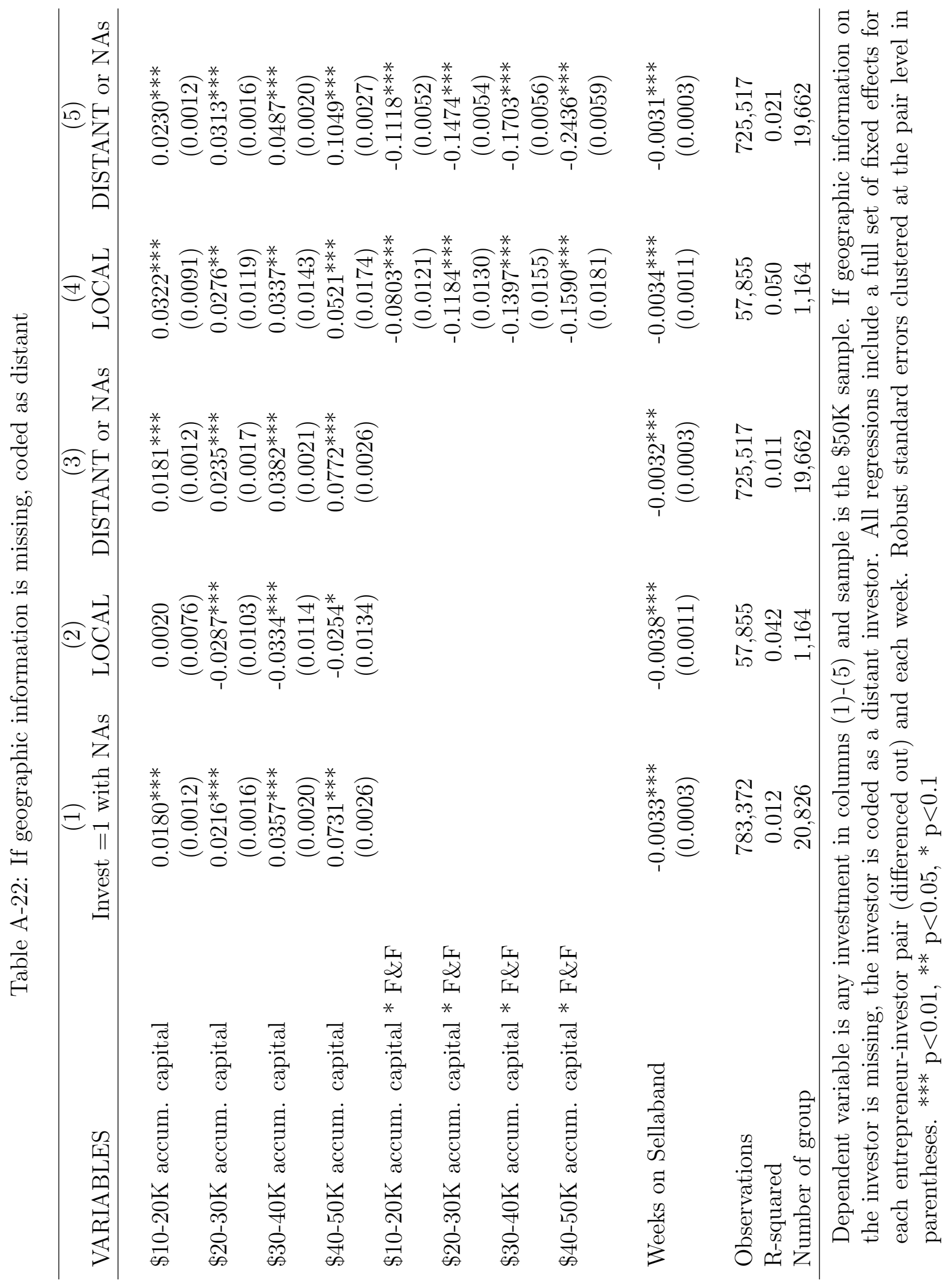


Table A-23: Distant and local in same regression

\begin{tabular}{|c|c|c|}
\hline VARIABLES & $\begin{array}{c}(1) \\
\text { Invest=1 }\end{array}$ & $\begin{array}{c}(2) \\
\text { Invest=1 }\end{array}$ \\
\hline \$10-20K accum. capital & $\begin{array}{c}-0.0228^{* * *} \\
(0.0059)\end{array}$ & $\begin{array}{c}0.0045 \\
(0.0073)\end{array}$ \\
\hline$\$ 20-30 \mathrm{~K}$ accum. capital & $\begin{array}{c}-0.0376^{* * *} \\
(0.0064)\end{array}$ & $\begin{array}{c}0.0119 \\
(0.0087)\end{array}$ \\
\hline$\$ 30-40 \mathrm{~K}$ accum. capital & $\begin{array}{c}-0.0369^{* * *} \\
(0.0074)\end{array}$ & $\begin{array}{l}0.0230^{*} \\
(0.0118)\end{array}$ \\
\hline$\$ 40-50 \mathrm{~K}$ accum. capital & $\begin{array}{c}-0.0276^{* * *} \\
(0.0079)\end{array}$ & $\begin{array}{c}0.0449^{* * *} \\
(0.0149)\end{array}$ \\
\hline$\$ 10-20 \mathrm{~K}$ accum. capital $*$ F\&F & & $\begin{array}{c}-0.0791^{* * *} \\
(0.0117)\end{array}$ \\
\hline$\$ 20-30 \mathrm{~K}$ accum. capital $*$ F\&F & & $\begin{array}{c}-0.1111^{* * *} \\
(0.0125)\end{array}$ \\
\hline$\$ 30-40 \mathrm{~K}$ accum. capital $*$ F\&F & & $\begin{array}{c}-0.1296^{* * *} \\
(0.0150)\end{array}$ \\
\hline$\$ 40-50 \mathrm{~K}$ accum. capital $* \mathrm{~F} \& \mathrm{~F}$ & & $\begin{array}{c}-0.1476^{* * *} \\
(0.0176)\end{array}$ \\
\hline$\$ 10-20 \mathrm{k}$ accum. capital $*$ Distant & $\begin{array}{c}0.0447^{* * *} \\
(0.0059)\end{array}$ & $\begin{array}{c}0.0192^{* * *} \\
(0.0074)\end{array}$ \\
\hline$\$ 20-30$ k accum. capital $*$ Distant & $\begin{array}{c}0.0653^{* * *} \\
(0.0063)\end{array}$ & $\begin{array}{c}0.0206^{* *} \\
(0.0086)\end{array}$ \\
\hline$\$ 30-40 \mathrm{k}$ accum. capital $*$ Distant & $\begin{array}{c}0.0804^{* * *} \\
(0.0072)\end{array}$ & $\begin{array}{c}0.0269^{* *} \\
(0.0117)\end{array}$ \\
\hline$\$ 40-50 \mathrm{k}$ accum. capital $*$ Distant & $\begin{array}{c}0.1149^{* * *} \\
(0.0077)\end{array}$ & $\begin{array}{c}0.0619^{* * *} \\
(0.0149)\end{array}$ \\
\hline$\$ 10-20 \mathrm{k}$ accum. capital $*$ Distant $*$ F\&F & & $\begin{array}{l}-0.0119 \\
(0.0133)\end{array}$ \\
\hline$\$ 20-30 \mathrm{k}$ accum. capital $*$ Distant $*$ F\&F & & $\begin{array}{c}-0.0265^{*} \\
(0.0143)\end{array}$ \\
\hline$\$ 30-40 \mathrm{k}$ accum. capital $*$ Distant $*$ F\&F & & $\begin{array}{c}-0.0350^{* *} \\
(0.0166)\end{array}$ \\
\hline$\$ 40-50 \mathrm{k}$ accum. capital $*$ Distant $*$ F\&F & & $\begin{array}{c}-0.1043^{* * *} \\
(0.0193)\end{array}$ \\
\hline Weeks on Sellaband & $\begin{array}{c}-0.0033^{* * *} \\
(0.0003)\end{array}$ & $\begin{array}{c}-0.0031^{* * *} \\
(0.0003)\end{array}$ \\
\hline Observations & 709,471 & 709,471 \\
\hline R-squared & 0.013 & 0.019 \\
\hline Number of group & 18,827 & 18,827 \\
\hline
\end{tabular}

Dependent variable is any investment in columns (1)-(2) and sample is the $\$ 50 \mathrm{~K}$ sample. Distant and local are presented here in same regression (i.e. interaction term). All regressions include a full set of fixed effect6(for each entrepreneur-investor pair (differenced out) and each week. Robust standard errors clustered at the pair level in parentheses. ${ }^{* * *} \mathrm{p}<0.01,{ }^{* *} \mathrm{p}<0.05,{ }^{*} \mathrm{p}<0.1$ 


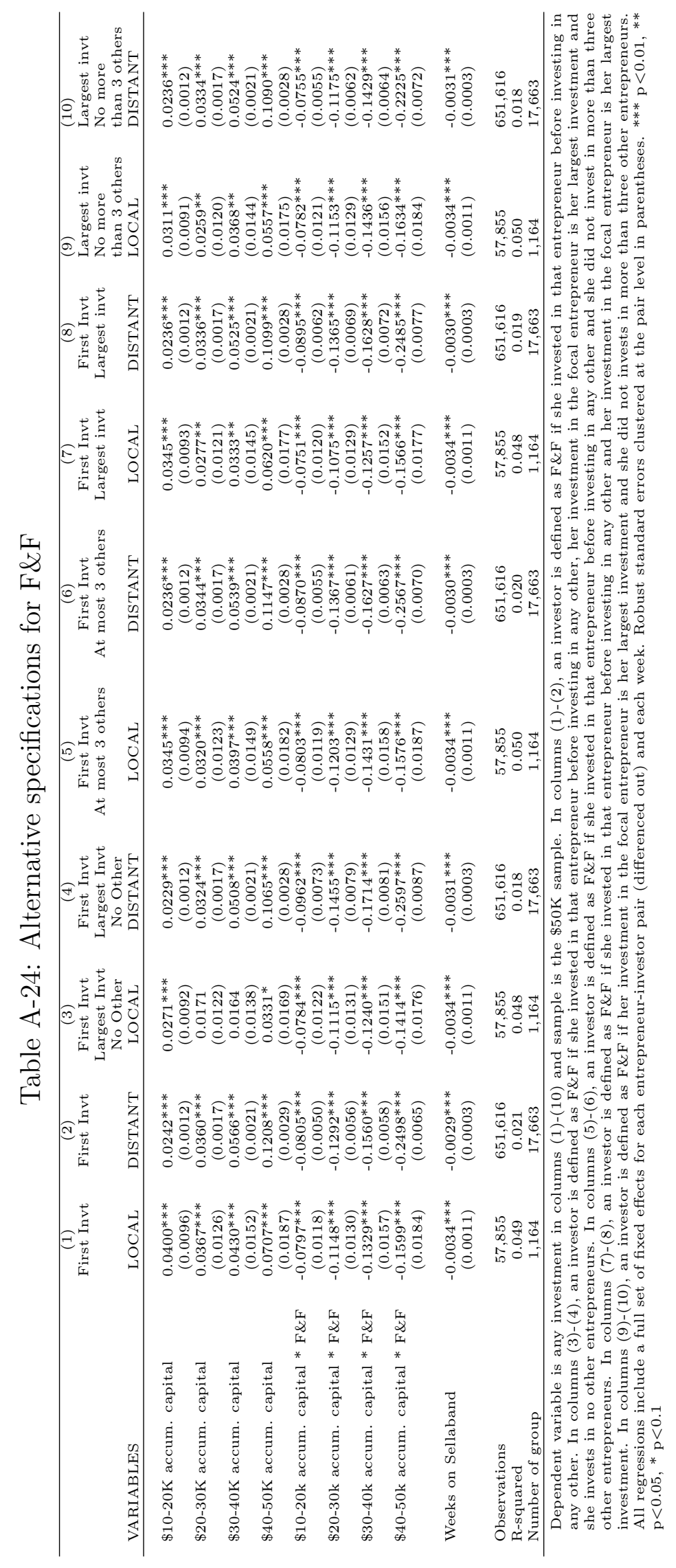

